\author{
Universidade de São Paulo \\ Faculdade de Medicina de Ribeirão Preto \\ Departamento de Bioquímica e Imunologia
}

Mariana de Souza Rocha

Estudo da eficiência enzimática fúngica nas reações de transesterificação e hidrólise a partir de óleos vegetais nativos visando aplicações biotecnológicas

Ribeirão Preto - SP 


\author{
Universidade de São Paulo \\ Faculdade de Medicina de Ribeirão Preto \\ Departamento de Bioquímica e Imunologia
}

\begin{abstract}
Estudo da eficiência enzimática fúngica nas reações de transesterificação e hidrólise a partir de óleos vegetais nativos visando aplicações biotecnológicas
\end{abstract}

\title{
Mariana de Souza Rocha
}

\begin{abstract}
Dissertação apresentada ao Programa de Pós-Graduação em Bioquímica da Faculdade de Medicina de Ribeirão Preto da Universidade de São Paulo, como parte dos requisitos para a obtenção do título de Mestre em Ciências.

Área de concentração Bioquímica.
\end{abstract}

Orientadora: Prof. ${ }^{a}$ Dr $^{\mathrm{a}}$. Maria de Lourdes Teixeira de Moraes Polizeli Co-orientadora: Dra. Ana Claudia Vici

Ribeirão Preto - SP 
Autorizo a reprodução e divulgação total ou parcial deste trabalho, por qualquer meio convencional ou eletrônico, para fins de estudo e pesquisa, desde que citada a fonte.

Catalogação da Publicação

Serviço de Documentação

Faculdade de Medicina de Ribeirão Preto - USP

\section{Ficha Catalográfica}

\section{Rocha, M. S}

Estudo da eficiência enzimática fúngica nas reações de transesterificação e hidrólise a partir de óleos vegetais nativos visando aplicações biotecnológicas / Mariana de Souza Rocha; Orientadora: Profa. Dra. Maria de Lourdes Teixeira de Moraes Polizeli. Ribeirão Preto - São Paulo, 2019.

$$
140 \text { p.: il.; } 30 \mathrm{~cm}
$$

Dissertação (Mestrado) - Faculdade de Medicina de Ribeirão Preto, Universidade de São Paulo, Ribeirão Preto, 2019. Área de concentração: Bioquímica.

1. Lipase; 2. Fungos Filamentosos; 3. Imobilização;

4. Transesterificação enzimática; 5. Hidrólise 
Nome: ROCHA, M.S

Título: Estudo da eficiência enzimática fúngica nas reações de transesterificação e hidrólise a partir de óleos vegetais nativos visando aplicações biotecnológicas

Dissertação apresentada ao programa de Pósgraduação em Bioquímica da Faculdade de Medicina de Ribeirão Preto da Universidade de São Paulo, para obtenção do título de Mestre em Ciências.

Área de Concentração: Bioquímica

Aprovado em:

Banca Examinadora

Prof. Dr.

Julgamento:

Prof. Dr.

Julgamento:

Prof. Dr.

Julgamento:

Prof. Dr.

Julgamento:
Instituição:

Assinatura:

Instituição:

Assinatura:

Instituição:

Assinatura:

Instituição:

Assinatura:

Ribeirão Preto - São Paulo 


\section{Apoio e Suporte à pesquisa}

Este trabalho foi realizado com apoio das seguintes entidades e instituições:

1) Fundação de Amparo à Pesquisa do Estado de São Paulo - FAPESP, (Processo número: 2017/25011-6)

2) Coordenação de Aperfeiçoamento de Pessoal de Nível Superior-CAPES, Demanda Social.

3) Conselho Nacional de Desenvolvimento Científico e Tecnológico CNPq, Chamada MCTI/CNPq n ${ }^{\circ}$ 40/2013

4) Faculdade de Medicina de Ribeirão Preto - FMRP/USP.

5) Faculdade de Filosofia Ciências e Letras de Ribeirão Preto FFCLRP/USP

6) Departamento de Genética de Ribeirão Preto - FMRP/USP. 


\section{Normalização Adotada}

Esta dissertação está de acordo com:

Diretrizes para apresentação de dissertações e teses da USP: parte I (ABNT) / Sistema Integrado de Bibliotecas da USP; Vânia Martins Bueno de Oliveira Funaro, coordenadora; Vânia Martins Bueno de Oliveira Funaro... [et al.]. --3. ed. rev., ampl. mod. - - São Paulo: SIBiUSP, 2016. 100p.: il. -- (Cadernos de estudos; 9)

DOI: $10.11606 / 9788573140606$ 


\section{AGRADECIMENTOS}

Primeiramente, agradeço a Deus por sempre me abençoar e me fazer alcançar objetivos tão sonhados na minha vida.

Aos meus pais, Dilermando e Ana Maria, e irmãos, Rafael e Débora, meu eterno agradecimento, pelo amor, apoio e estímulo que me tornaram capaz de suportar todos os desafios até a conclusão deste trabalho.

Ao meu noivo e companheiro Guilherme, pelo amor, momentos de carinho, conselhos e por sempre me incentivar a crescer. Obrigada por sempre compartilhar sonhos comigo.

À minha orientadora Maria de Lourdes T. M. Polizeli, por ter me acolhido tão bem em sua família científica, apoiando minhas decisões e compartilhando conhecimentos que tanto contribuíram para a minha carreira acadêmica.

À minha co-orientadora Ana Claudia Vici, por sempre me direcionar e me acalmar nos momentos de ansiedade.

À Mariana Cereia e Maurício Oliveira, pelo auxílio técnico e primordial no desenvolvimento deste trabalho.

Aos meus colegas de bancada: Ana Paula Assis, Alex, Malena, Enrico, Juliana, Vanessa, Manu, José, Rosy, Tássio, Ana Silvia, Thiago, Paula e Inaiá por todas as dicas, momentos de descontração no almoço e experiências compartilhadas. Desejo a estas pessoas muitas felicidades e grandes realizações profissionais.

Ao professor Anizio Marcio de Faria, Andressa Tironi Vieira e demais membros do laboratório de Pesquisas em Materiais de Separação e Cromatografia Química, por toda disposição, auxiliando nas análises dos meus experimentos e trazendo grandes resultados para este trabalho.

Ao departamento de Bioquímica juntamente com a Faculdade de Medicina de Ribeirão Preto-USP por propiciar minha formação científica, pelo apoio e oportunidade de pós-graduação. Ao departamento da FFCLRP pelo apoio estrutural.

A FAPESP pelo auxílio financeiro (Processo número: 2017/25011-6).

A CAPES pela disponibilidade dos recursos financeiros.

E, finalmente, a todos de maneira geral que contribuíram direta ou indiretamente para que este trabalho se realizasse, meus sinceros agradecimentos. 
"Em seu coração o homem planeja o seu caminho, mas o Senhor determina os seus passos." (BÍBLIA, Provérbios 16:9) 


\section{RESUMO}

ROCHA, M. S. Estudo da eficiência enzimática fúngica nas reações de transesterificação e hidrólise a partir de óleos vegetais nativos visando aplicações biotecnológicas. Dissertação (Mestrado em Bioquímica) - Faculdade de Medicina de Ribeirão Preto, Universidade de São Paulo, Ribeirão Preto; 2019.

O presente trabalho objetivou identificar os melhores fungos produtores de lipases com capacidade de transesterificação e hidrólise de óleos. Os fungos foram selecionados da Micoteca da Faculdade de Filosofia, Ciências e Letras de Ribeirão Preto/USP, no Laboratório de Microbiologia e Biologia Celular para o estudo da atividade de lipase na sua forma livre e imobilizada, com o objetivo de sintetizar produtos para aplicações biotecnológicas. A etapa de screening foi concluída com a seleção dos fungos termófilos Scytalidium thermophilum e Humicola grisea e do fungo mesófilo Aspergillus phoenicis por terem apresentado as melhores taxas de atividade enzimática e produção de proteína extracelular. As melhores condições de cultivos foram padronizadas como: o meio de cultura SR (Segato-Rizzatti) adicionado 1\% de óleo de girassol, buriti e soja para $A$. phoenicis, S. thermophilum e $H$. grisea, respectivamente. Ao verificar a baixa estabilidade térmica das lipases produzidas por $S$. thermophilum e A. phoenicis na forma livre, foi realizada a imobilização de suas lipases nos suportes Octyl-sepharose, Butylsepharose, Sepabeads C-18, PEI-agarose, MANAE-agarose e Duolite. Para as lipases de S. thermophilum imobilizadas em Sepabeads C-18 (retenção 98,59\%) e Duolite (retenção $98,73 \%$ ) observou-se maior estabilidade a $50{ }^{\circ} \mathrm{C}$ e em $\mathrm{pH} 6$ e 7 . O derivado de Duolite foi muito estável nos solventes ciclohexano, etanol e acetona, mantendo atividade residual acima de $70 \%$ após 24 horas de incubação. Para as lipases de A. phoenicis, o suporte Octyl-sepharose (retenção 98,83\%) foi satisfatoriamente estável na temperatura de $50{ }^{\circ} \mathrm{C}$ e pH 6, além dos solventes ciclohexano e hexano. Adicionalmente, a imobilização da lipase de $A$. phoenicis em Octyl-sepharose levou a uma hiperativação enzimática. Através de um screening para a reação de transesterificação, o derivado de Duolite das lipases de $S$. thermophilum foi selecionado para a continuidade dos estudos para produção de biodiesel. Etanol foi utilizado para os ensaios de transesterificação por ser uma alternativa renovável ao metanol. Ao seguir a metodologia de etanol:óleo de girassol (1:2) adicionado de 10\% (m/v óleo) de derivado de Duolite e $82 \%$ de ciclohexano, obteve-se teor total de ésteres etílicos de 53,78\%. O biodiesel produzido foi submetido a análises físico-químicas e obteve-se os seguintes valores: índice de acidez de 0,56 $\mathrm{mg} \mathrm{NaOH} / \mathrm{g}$ e índice de iodo de 42,3 $\mathrm{g} \mathrm{I} / 2 / 100 \mathrm{~g}$ de amostra de biodiesel, demonstrando-se a adequação do produto nas legislações vigentes que determinam a qualidade do biocombustível. O rendimento da transesterificação do óleo de girassol foi de $74 \%$. A lipase de $A$. phoenicis imobilizada em Octyl-sepharose foi utilizada para a reação de hidrólise dos óleos vegetais soja, buriti, açaí, pracaxi e ojon e manteiga de tucumã. A concentração de ácidos graxos liberados foi quantificada através do método colorimétrico sulfofosfo-vanilina, resultando na hidrólise dos óleos de buriti $(3,4$ $\mathrm{mg} / \mathrm{mL})$, açaí $(3,06 \mathrm{mg} / \mathrm{mL})$ e ojon $(2,27 \mathrm{mg} / \mathrm{mL})$ em ácidos graxos totais. Os derivados desenvolvidos nesse trabalho possuem características interessantes para 0 desenvolvimento de bioprocessos a serem aplicados na indústria.

Palavras-chaves: lipase, fungos, imobilização, transesterificação, hidrólise 


\begin{abstract}
ROCHA, M. S. Study of fungal enzymatic efficiency in transesterification and hydrolysis reactions from native vegetable oils for biotechnological applications. Dissertation (Master's degree in Biochemistry) - Faculdade de Medicina de Ribeirao Preto, Sao Paulo University, Ribeirao Preto; 2019.

The present work aimed to identify the best fungal producers of lipases with efficient capacity of transesterification and hydrolysis reactions. The fungi were selected from the Library of Faculdade de Filosofia, Ciências e Letras de Ribeirão Preto/USP, located in the Laboratory of Microbiology and Cell Biology for the study of lipase activity in its free and immobilized form, with the objective of synthesizing products for biotechnological applications. The screening stage was concluded with the selection of the thermophilic fungi Scytalidium thermophilum and Humicola grisea and the mesophilic fungus Aspergillus phoenicis for presenting the best rates of enzymatic activity and production of extracellular protein. The best culture conditions were standardized as: SR culture medium (Segato-Rizzatti) added of 1\% sunflower oil, buriti and soybean for A. phoenicis, S. thermophilum and H. grisea, respectively. After the verification of low thermical stability of the free lipase produced by $A$. phoenicis and $S$. thermophilum, it was used the immobilization technique on Octyl-sepharose, Butylsepharose, C-18 Sepabeads, PEI-agarose, Duolite and MANAE-agarose. For $S$. thermophilum lipases immobilized on Sepabeads C-18 (retention 98.59\%) and Duolite (retention $98.73 \%$ ) better stability was observed at $50^{\circ} \mathrm{C}$ and at $\mathrm{pH} 6$ and 7 . The Duolite derivative was very stable in the solvents cyclohexane, ethanol and acetone, maintaining residual activity above $70 \%$ after 24 hours of incubation. For $A$. phoenicis lipases, the Octyl-sepharose support (retention $98.83 \%$ ) was satisfactorily stable at $50^{\circ} \mathrm{C}$ and $\mathrm{pH} 6$, plus at cyclohexane and hexane solvents solutions. In addition, the immobilization of $A$. phoenicis lipase on Octyl-sepharose led to enzymatic hyperactivation. Through a screening for the transesterification reaction, the Duolite derivative for the $S$. thermophilum lipases was selected for the continuation of the studies for biodiesel production. Ethanol was used for the transesterification tests due to its sustainability characteristics compared to methanol. Following the methodology of ethanol:sunflower oil (1:2) added with $10 \%$ (w/v oil) of Duolite derivative and $82 \%$ of cyclohexane, the total ethyl ester content produced was $53.78 \%$. The biodiesel produced was submitted to physic-chemical analysis and the following values were obtained: acid index of $0.56 \mathrm{mg}$ $\mathrm{NaOH} / \mathrm{g}$ and iodine content index of $42.3 \mathrm{~g} \mathrm{I} / 100 \mathrm{~g}$ of biodiesel sample, demonstrating the aptness of the product in the current legislation that determines the biofuel quality. The yield of the transesterification using sunflower oil as substrate was $74 \%$. The lipase of $A$. phoenicis immobilized on Octyl-sepharose was used for the hydrolysis reaction of soybean, buriti, açaí, pracaxi and ojon oils and tucumã butter. The concentration of fatty acids released was quantified by the sulphophosphorus-vanillin colorimetric method, resulting in the hydrolysis of buriti $(3.4 \mathrm{mg} / \mathrm{mL})$, açai $(3.06 \mathrm{mg} / \mathrm{mL})$ and ojon $(2.27$ $\mathrm{mg} / \mathrm{mL}$ ) oils in total fatty acids content. The derivatives developed in this work have interesting characteristics for the development of bioprocesses to be applied in the industry.
\end{abstract}

Palavras-chaves: lipase, fungi, immobilization, transesterification, hydrolysis 


\section{LISTA DE FIGURAS}

Figura 1. Representação esquemática da conformação $\alpha / \beta$ hidrolases das lipases ..........2

Figura 2. Representação da "tampa" característica da lipase e seu equilíbrio dinâmico entre as conformações aberta e fechada ............................................... 3

Figura 3. Reações catalisadas por lipase ................................................................. 4

Figura 4. Mecanismo de catálise da lipase ..................................................................... 5

Figura 5. Esquema de processo e formação de produtos da reação de transesterificação a

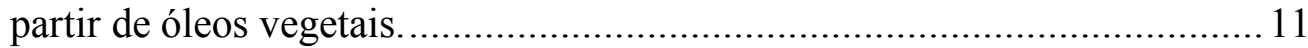

Figura 6. Filtração à vácuo do extrato bruto suplementado com $1 \%$ de óleo de soja, para obtenção dos micélios em papel Whatman $\mathrm{n}^{\circ} 1$

Figura 7. Sequência de preparação da metodologia de quantificação de ácidos graxos totais em $\mathrm{mg} / \mathrm{mL}$

Figura 8. Screening dos fungos filamentos, cultivados em tributirina $1 \%$ como fonte de carbono.....

Figura 9. Avaliação da concentração de proteínas e atividade específica dos extratos brutos extracelulares

Figura 10. Avaliação da concentração de proteínas e atividade específica intracelulares

Figura 11. Efeito dos meios de cultivos SR e Khanna na produção de lipases por (A) $S$. thermophilum (B) A. phoenicis e (C) H. grisea ...................................... 44

Figura 12. Influência de diferentes fontes de carbono para a produção de lipases ........48

Figura 13. Extrato bruto dos fungos $S$. thermophilum e A. phoenicis obtidos após 72 horas de cultivo

Figura 14. Influência do método de precipitação com sulfato de amônio seguido de diálise

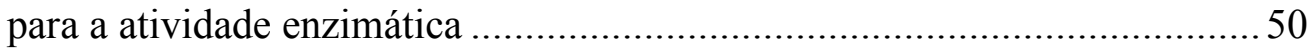

Figura 15. Estabilidade térmica da lipase livre ......................................................... 53

Figura 16. Ensaio de imobilização da lipase de A. phoenicis em suportes hidrofóbicos 57

Figura 17. Ensaio de imobilização da lipase de A. phoenicis em suportes iônicos .........58

Figura 18. Ensaio de imobilização da lipase de $S$. thermophilum em suportes hidrofóbicos

Figura 19. Ensaio de imobilização da lipase de S. thermophilum em suportes iônicos.. 62

Figura 20. Estabilidade térmica dos derivados de A. phoenicis em Octyl-sepharose..... 64

Figura 21. Estabilidade térmica dos derivados de A. phoenicis em Butyl-sepharose..... 65

Figura 22. Estabilidade térmica dos derivados de A. phoenicis em Sepabeads C-18 ..... 66

Figura 23. Estabilidade ao $\mathrm{pH}$ da lipase de A. phoenicis imobilizada em Octyl-sepharose

Figura 24. Estabilidade ao pH dos derivados de A. phoenicis em Butyl-sepharose....... 69

Figura 25. Estabilidade ao pH dos derivados de A. phoenicis em Sepabeads C-18...... 70 
Figura 26. Estabilidade térmica dos derivados de $S$. thermophilum em Octyl-sepharose .

Figura 27. Estabilidade térmica dos derivados de $S$. thermophilum em Sepabeads C-18 73

Figura 28. Estabilidade térmica dos derivados de S. thermophilum em Duolite. 74

Figura 29. Estabilidade em $\mathrm{pH}$ dos derivados de $S$. thermophilum em Octyl-sepharose 76 Figura 30. Estabilidade em pH dos derivados de S. thermophilum em Sepabeads C-1877 Figura 31. Estabilidade em $\mathrm{pH}$ dos derivados de $S$. thermophilum em Duolite............. 78

Figura 32. Estabilidade dos derivados em diferentes solventes em 24 horas ............... 82

Figura 33. Ensaio de quantificação colorimétrica de transesterificação ........................ 85

Figura 34. Ensaio de transesterificação de pNPP pelos derivados selecionados em diferentes temperaturas e álcoois. 86

Figura 35. Cromatogramas das amostras para qualificação e quantificação de ésteres metílicos 88

Figura 36. Cromatogramas das leituras das amostras em CG, para qualificação e quantificação de ésteres etílicos.

Figura 37. Reutilização do derivado St-Duolite utilizado na reação de transesterificação por 3 semanas.

Figura 38. Amostras submetidas ao método colorimétrico sulfofosfo-vanilina para quantificação de ácidos graxos livres.

Figura 39. Concentração de ácidos graxos livres $(\mathrm{mg} / \mathrm{mL})$ obtidos após hidrólise de óleos vegetais pelo derivado Ap-Octyl. 


\section{LISTA DE TABELAS}

Tabela 1. Concentração aproximada de ácidos graxos oleico (C18:1) e linoleico (18:2) dos óleos vegetais selecionados.

Tabela 2. Comparação de algumas características de enzima livres e enzimas imobilizadas.

Tabela 3. Dosagem enzimática dos extratos brutos obtidos em diferentes temperaturas 38

Tabela 4. Valores de atividade hidrolítica $(\mathrm{U} / \mathrm{mL})$ das lipases intracelulares obtidas a partir dos micélios macerados dos fungos selecionados.

Tabela 5. Atividade lipolítica e produção de proteínas obtidas nos melhores tempos de cultivo fúngico para o crescimento em meio SR, suplementado com $1 \%$ de óleo de soja.

Tabela 6. Valores de $t_{50}$ em minutos da lipase livre de A. phoenicis e $S$. thermophilum em

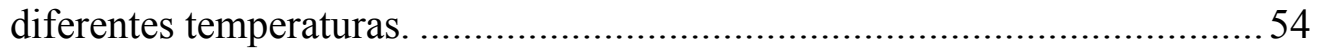

Tabela 7. Parâmetros de imobilização de lipase do fungo A. phoenicis após 24 horas.. 56

Tabela 8. Parâmetros de imobilização de lipase do fungo $S$. thermophilum após 24 horas

Tabela 9. Valores de $\mathrm{t}_{50}$ em minutos dos derivados de A. phoenicis em diferentes temperaturas

Tabela 10. Valores de $t_{50}$ em minutos dos derivados de $A$. phoenicis em diferentes pHs71

Tabela 11. Valores de $t_{50}$ em minutos dos derivados de $S$. thermophilum em diferentes temperaturas.

Tabela 12. Valores de $t_{50}$ em minutos dos derivados de $S$. thermophilum em diferentes $\mathrm{pH}$

Tabela 13. Screening de transesterificação utilizando o substrato sintético pNPP .......84 84

Tabela 14. Identificação e quantificação de ésteres metílicos das amostras analisadas . 89

Tabela 15. Identificação e quantificação de ésteres etílicos nas amostras após reação de transesterificação com diferentes óleos vegetais

Tabela 16. Identificação e quantificação de ésteres etílicos nas amostras após reação de transesterificação com diferentes óleos vegetais .

Tabela 17. Avaliação do efeito do pH do meio reacional para a hidrólise de pNPP por ApOctyl.

Tabela 18. Avaliação do efeito da temperatura na reação de hidrólise de pNPP por ApOctyl..... 


\section{LISTA DE ABREVIATURAS}

$\%$ - Porcentagem

(m/v) - Razão massa e volume (v/v) - Razão entre volume

$<-$ Menor que

$>$ - Maior que

${ }^{\circ} \mathrm{C}$ - Graus Celsius

$\mu \mathrm{L}-$ Microlitro

$20 \mathrm{X}-20$ vezes concentrado

atm. - Pressão atmosférica

BSA - Soro Albumina Bovina

$g$ - Força Gravitacional

g - Grama

$\mathrm{h}-$ Hora

L - Litro

MANAE - Monoamino-N-aminoetil

mg - Miligramas

$\min$ - Minuto

$\mathrm{mL}$ - Mililitro

$\mathrm{mg} / \mathrm{mL}$ - Concentração de proteína

$\mathrm{mM}$ - Milimolar

$\mathrm{NaOH}$ - Hidróxido de sódio

PEI - Polietilenoimina

$\mathrm{pH}$ - Potencial hidrogeniônico

pNPP - 4-nitrofenil-palmitato

q.s.p.: - Quantidade suficiente para

rpm - Rotação por minuto

$\mathrm{t}_{50}$ - Tempo para $50 \%$ de um determinado parâmetro

U - Unidade de atividade enzimática

$\mathrm{U} / \mathrm{g}$ - Unidade de atividade enzimática por grama de derivado

U/mg - Unidades de atividade enzimática por miligrama de proteína

$\mathrm{U} / \mathrm{mL}$ - Unidades de atividade enzimática por mililitro de solução 


\section{SUMÁRIO}

RESUMO

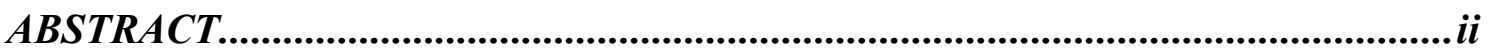

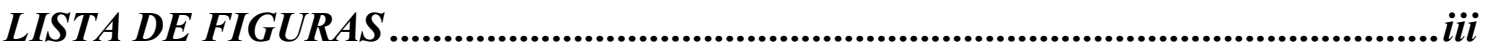

LISTA DE TABELAS ...................................................................................... v

LISTA DE ABREVIATURAS...................................................................... vi

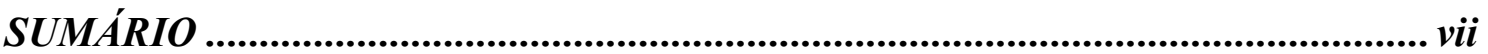

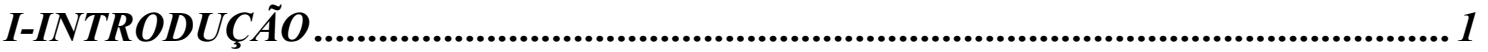

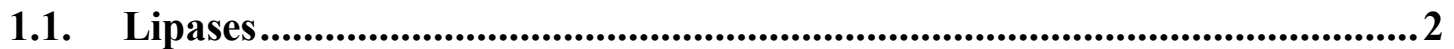

1.1.1. Definição e reações catalisadas por lipases...............................................

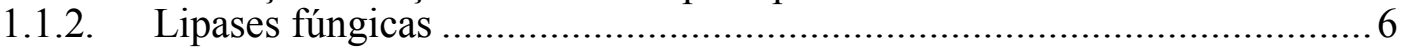

1.2. Reação de Hidrólise a partir de óleos vegetais para a obtenção de ácidos graxos poli-insaturados .....................................................................................

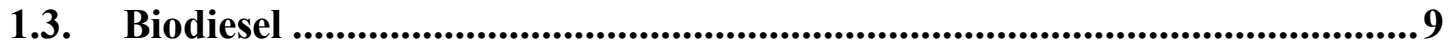

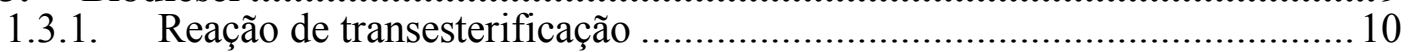

1.3.2. Transesterificação alcalina e ácida ........................................................ 11

1.3.3. Transesterificação enzimática ............................................................ 12

1.4. Imobilização enzimática ...............................................................................13

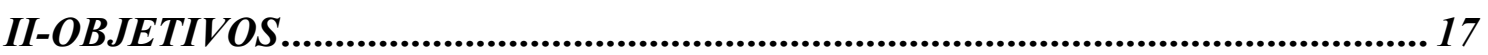

2.1. Objetivo Geral .................................................................................................. 18

2.2. Objetivos Específicos ........................................................................................ 18

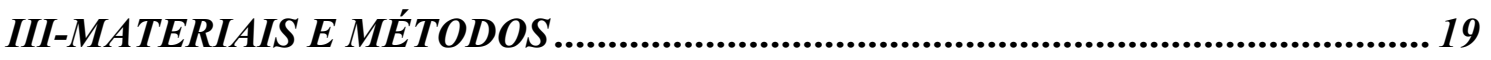

3.1. Screening dos fungos produtores de lipase ........................................................20

3.2. Obtenção das culturas em meio fermentação submersa .................................20

3.3. Ensaio de atividade de lipase............................................................................... 21

3.4. Teste de viabilidade dos micélios.................................................................22

3.5. Determinação de Proteínas...........................................................................23

3.6. Otimização da produção de lipase .................................................................24

3.7. Concentração de proteínas do extrato bruto por sulfato de amônio ..............24

3.8. Termoinativação da enzima livre.................................................................24

3.9. Imobilização da lipase em suportes sólidos.......................................................25

3.10. Ensaios de estabilidade das lipases imobilizadas ............................................25

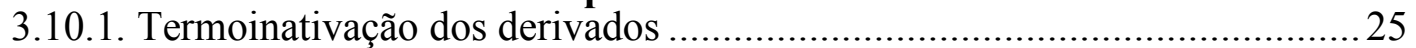

3.10.2. Estabilidade dos derivados a diferentes valores de $\mathrm{pH}$..............................2. 26

3.10.3. Estabilidade dos derivados a solventes orgânicos...........................................2

3.11. Reação de transesterificação utilizando substrato sintético..........................22

3.12. Reação de transesterificação enzimática........................................................28

3.13. Análise por Cromatografia Gasosa (CG).......................................................28

3.14. Análises físico-químicas do biodiesel produzido por catálise enzimática ...29

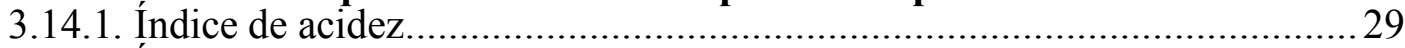

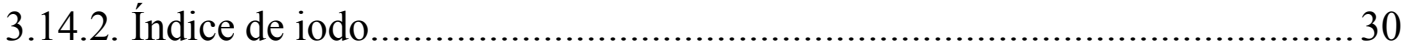


3.14.3. Cálculo do rendimento da transesterificação enzimática ......................... 31

3.15. Hidrólise dos óleos vegetais nativos................................................................31

3.16. Análise dos experimentos ................................................................................32

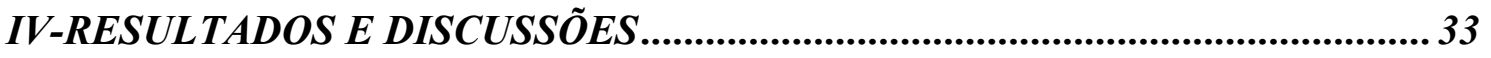

PARTE I - Screening e seleção de fungos filamentosos.......................................35

4.1.1. Screening dos fungos produtores de lipase em meio de cultivo sólido..........36

4.1.2. Fermentação submersa e detecção de atividade enzimática de lipase

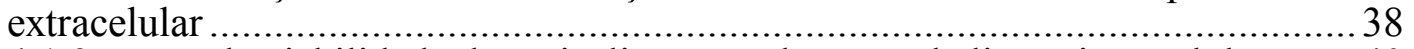

4.1.3. Teste de viabilidade dos micélios para obtenção de lipase intracelular........ 40

PARTE II - Melhoramento da produção de lipases por $S$. thermophilum, $A$.

phoenicis e H. grisea .......................................................................................................... 42

4.2.1. Padronização do meio de cultura e tempo de crescimento para fermentação

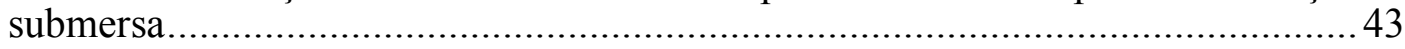

4.2.2. Influência das fontes de carbono para a produção de lipase extracelular .....45

4.2.3. Concentração de proteínas do extrato bruto por precipitação por sulfato de amônio e diálise.

PARTE III - Imobilização e caracterização das lipases de $S$. thermophilum e $\boldsymbol{A}$. phoenicis.

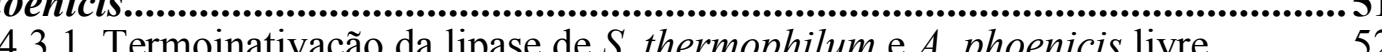

.3.1. Termoinativação da lipase de $S$. thermophilum e $A$. phoenicis livre ............55

4.3.2. Ensaio de imobilização da lipase em suportes sólidos hidrofóbicos e iônicos 54

4.3.3. Estabilidade dos derivados

4.3.4. Ensaios de estabilidade das lipases de S. thermophilum imobilizadas............ 71

4.3.5. Estabilidade em solventes dos derivados nos suportes selecionados.............. 81

PARTE IV - Aplicação Biotecnológica: Produção de Biodiesel através de transesterificação enzimática ...............................................................................8 83

4.4.1. Reação de transesterificação utilizando o substrato sintético pNPP..............84

4.4.2. Otimização da utilização do derivado para a reação de transesterificação ....85 85

4.4.3. Reação de transesterificação enzimática para a produção de biodiesel .......8 87

4.4.4. Análises físico-químicas do biodiesel produzido por transesterificação

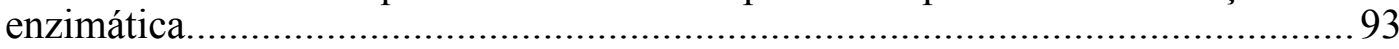

4.4.5. Reciclagem do derivado para reação de transesterificação ........................... 94

PARTE V - Aplicação Biotecnológica: Hidrólise enzimática para obtenção de ácidos graxos totais.

4.5.1. Otimização da utilização do derivado para a reação de hidrólise .................. 97

4.5.2. Hidrólise dos óleos vegetais ............................................................. 98

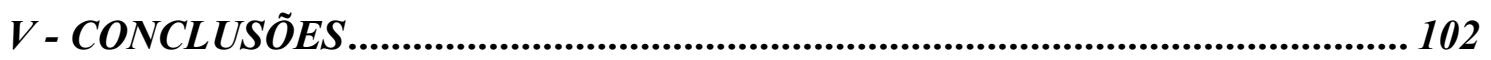

VI - REFER ÊNCIAS BIBLIOGRÁFICAS....................................................... 104

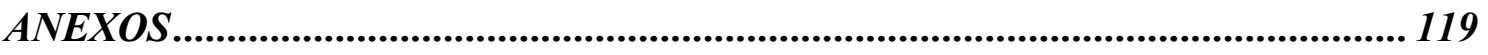

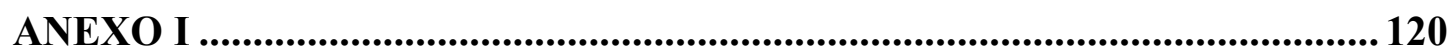

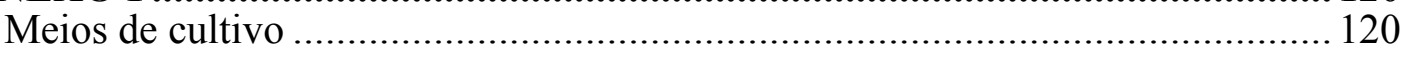

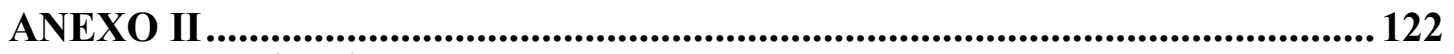

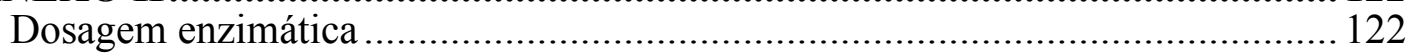

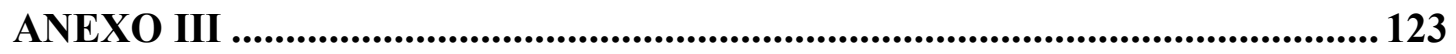

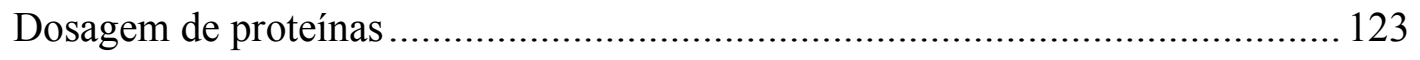

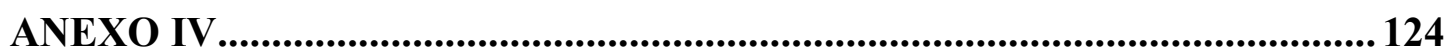

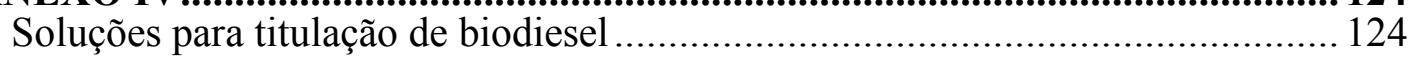


I-INTRODUÇÃO 


\subsection{Lipases}

\subsubsection{Definição e reações catalisadas por lipases}

As lipases são enzimas pertencentes à classe das serina-hidrolases (EC 3.1), capazes de atuar sobre ligações éster (triacilglicerol acilhidrolases, EC.3.1.1.3). Estas enzimas são extremamente versáteis e altamente eficientes. Elas desempenham um importante papel fisiológico convertendo triacilglicerídeos em moléculas mais polares, como diacilglicerol, monoacilglicerol, ácidos graxos livres e glicerol, na presença de água. São valorizadas comercialmente pois agem em condições moderadas de reação, são estáveis a solventes orgânicos e apresentam ampla especificidade em diferentes substratos (BRADY et al., 1990). Lipases são constituídas de $\alpha$ hélices e folhas $\beta$ em uma conformação $\alpha / \beta$ - hidrolase (Figura 1).

Em maioria, o seu sítio ativo é constituído por uma tríade catalítica que envolve os aminoácidos: serina, ácido aspártico e histidina (VIEIRA et al., 2006). O sítio ativo fica localizado dentro de uma cavidade hidrofóbica, nesta cavidade o ácido graxo se acomoda, favorecendo o alinhamento da ligação éster com o sítio ativo (BORNSCHEUER, 2002).

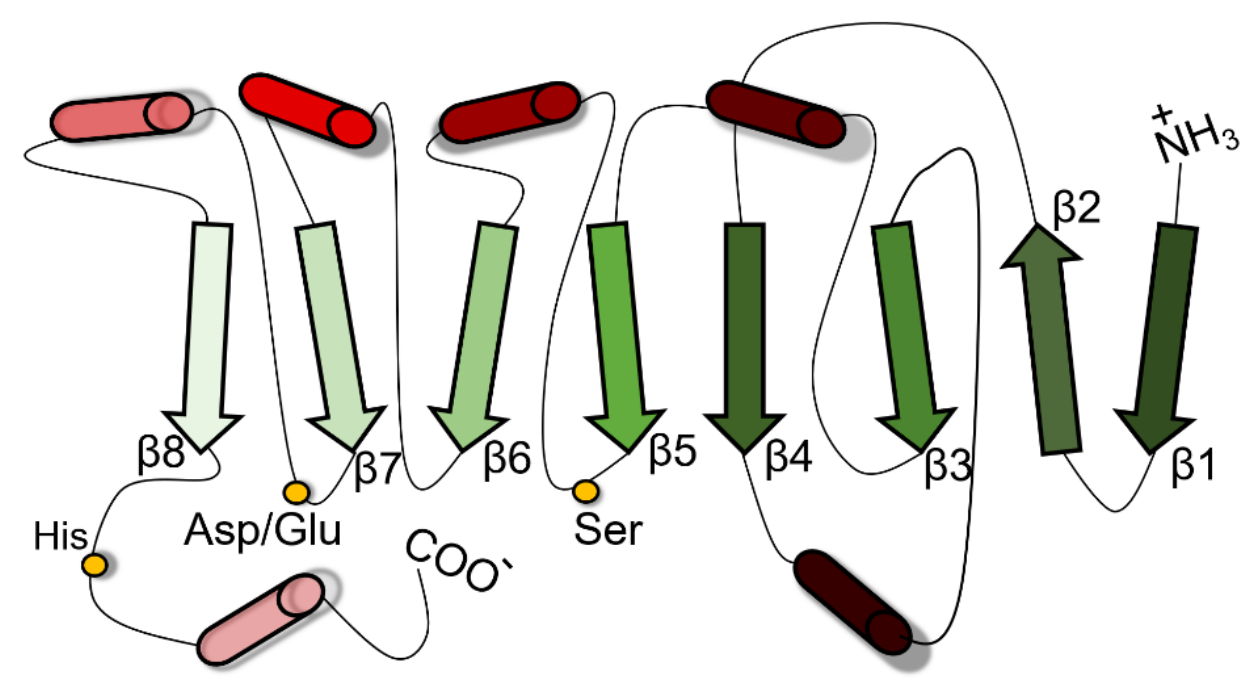

Figura 1. Representação esquemática da conformação $\alpha / \beta$ hidrolases das lipases. Estruturas de folhas $\beta$ (setas) e $\alpha$ hélice (cilindros). As posições preditas dos aminoácidos da tríade catalítica (His, Asp/Glu e Ser) estão representadas por círculos amarelos (PÉREZ et al, 2018). 
As lipases agem na interface óleo/água. Ao observar sua estrutura, a maioria das lipases apresentam uma cadeia de oligopeptídeos chamada de "lid" ou "tampa hidrofóbica" ou simplesmente "tampa", que ao estar fechada bloqueia o acesso do substrato ao sítio ativo. $\mathrm{Na}$ interface óleo/água a presença de interações iônicas, hidrofóbicas ou pontes de hidrogênio promovem a abertura da "tampa", permitindo o acesso do substrato ao sítio ativo (Figura 2) (PALOMO et al., 2006). De acordo com Bornscheuer (2002), as lipases em solução estão em equilíbrio dinâmico entre a forma aberta e fechada. A abertura da "tampa" pode ser facilitada pela adição de solventes orgânicos ou por molécula de detergente que se liga na região do sítio ativo. A superfície da lipase que possui a "tampa" quando está fechada é basicamente hidrofílica, mas quando esta se encontra aberta, a mudança conformacional da "tampa" expõe uma grande superfície hidrofóbica, permitindo acesso ao sítio ativo. Em adição, a interação da "tampa" com a interface óleo/água ou com micelas, favorece a ativação da lipase, ou seja, o sítio ativo se torna mais exposto para ligação com o substrato (FACCHINI et al., 2013). As lipases estão presentes em diversos organismos, como plantas, animais, fungos e bactérias, exercendo suas atividades em temperaturas entre $26^{\circ} \mathrm{C} \mathrm{e} 70{ }^{\circ} \mathrm{C}$, com uma faixa de $\mathrm{pH}$ ótimo entre 4 e 9 (GUPTA et al., 2004).

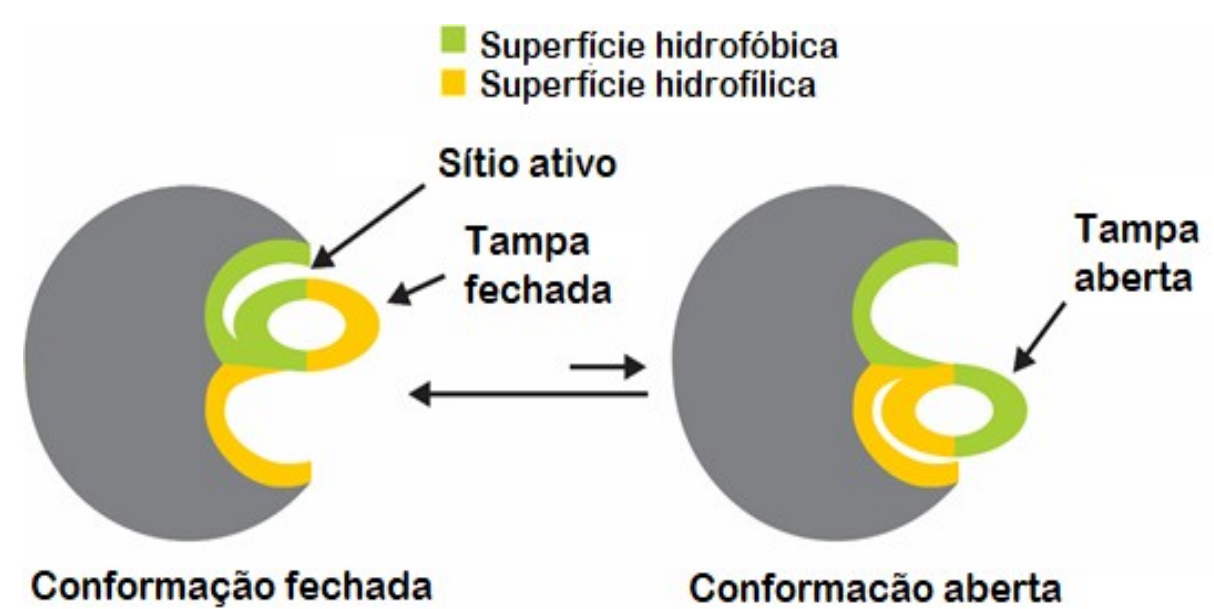

Figura 2. Representação da "tampa" característica da lipase e seu equilíbrio dinâmico entre as conformações aberta e fechada. $O$ equilíbrio químico ilustrado ocorre no momento da catálise reacional. Adaptado de PÉREZ et al. (2019).

Algumas vantagens da catálise realizada pelas lipases são: (a) solubilidade em água; (b) capacidade de catalisar reações de síntese de ésteres de glicerol e ácidos graxos, como: esterificação, transesterificação e alcoólise, não ausência de água; (c) alta 
estabilidade em solventes orgânicos; (d) elevada especificidade ao substrato; (e) quando imobilizada, facilita a reação de transesterificação e possui maior estabilidade físicoquímica e (f) não necessita de cofatores para promover sua reação (NARWAL, GUPTA, 2013; GHALY et al., 2010).

De acordo com Tsujisaka et al., (1977) ficou comprovado ser possível reverter a hidrólise de triacilglicerol no sentido da reação de esterificação pelo controle do teor de água no meio. Dessa forma, as lipases quando em meios com pouca disponibilidade de água adquirem a capacidade de catalisar reações de esterificação e transesterificação de glicerídeos (Figura 3). Quando estão presentes em meios orgânicos-aquosos ocorre um deslocamento do equilíbrio termodinâmico no sentido de hidrólise, portanto, as lipases catalisam a reação produzindo glicerol e ácidos graxos livres, através da clivagem de ligações do tipo éster em triglicerídeo (HASAN et al., 2009).

\section{Hidrólise e esterificação}<smiles>[R]OC([R])=O</smiles>

\section{Transesterificação}

\section{Acidolise}<smiles>[R]OC([R])=O</smiles><smiles>[R3]C(=O)O</smiles>

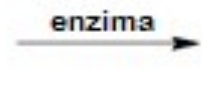

Alcoólise<smiles>[R]OC([R])=O</smiles><smiles>[R3]CO</smiles><smiles>[R]C[O+]=C([R])O</smiles><smiles>[R2]OC([R5])=O</smiles><smiles>[R]OC([R])=O</smiles><smiles>[R]CO</smiles>

Figura 3. Reações catalisadas por lipase. Tipo de reação depende dos grupos químicos dos substratos utilizados e da presença ou baixa/ausência de água no meio reacional. Adaptado de PÉREZ et al. (2019).

A reação de hidrólise catalisada por lipases é reversível e inicia-se com um ataque nucleofílico do oxigênio da hidroxila do resíduo serina ao carbono da carbonila da ligação éster do lipídeo (Figura 4). 
(1)

Mecanismo catalítico de lipases
(2)

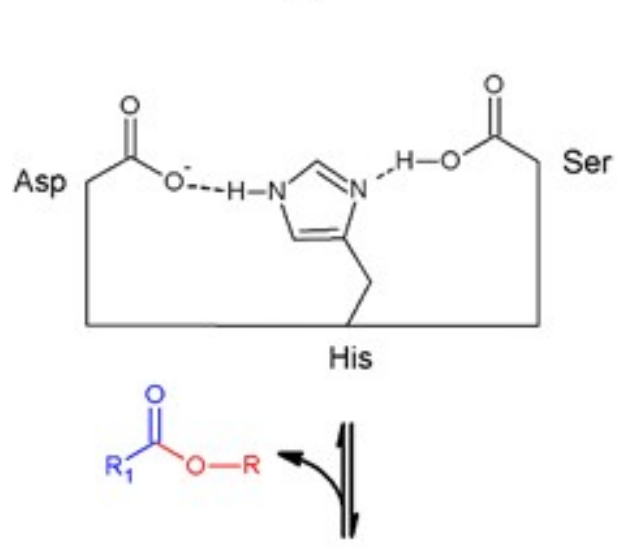

(4)

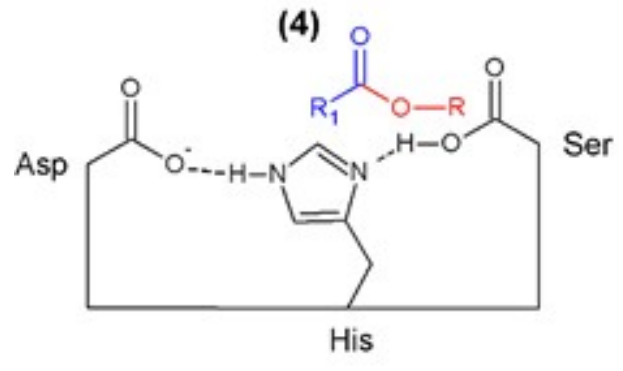

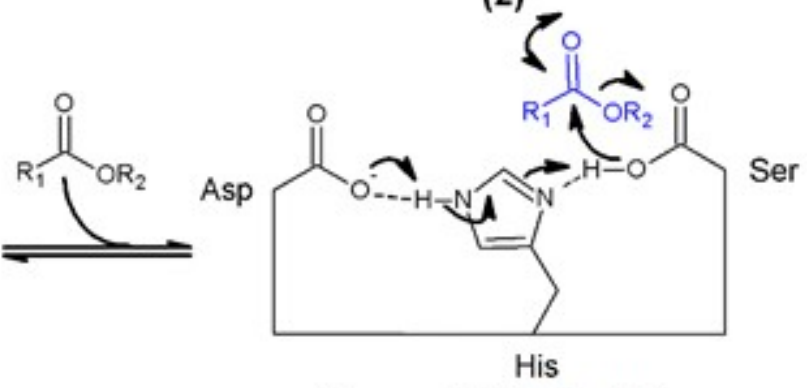

intermediärio tetraèdrico

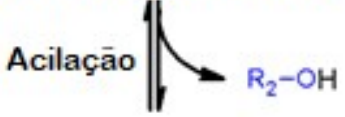

(3)

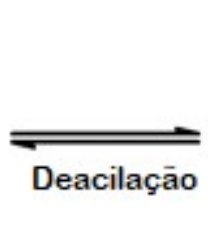

Asp

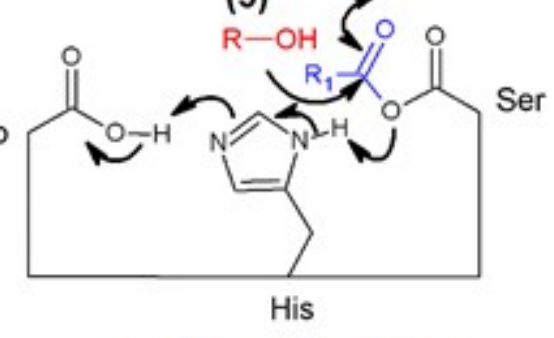

complexo acil-enzima

$\mathrm{ROH}=\mathrm{H}_{2} \mathrm{O}$ quando a reaçāo è hidrólise

$\mathrm{ROH}=$ outro aceptor quando a reaçāo è transesterificaçāo

Figura 4. Mecanismo de catálise da lipase. (1) Sítio ativo da lipase. (2) Ligação do lipídeo à enzima e ativação do resíduo de serina nucleofílico com formação do intermediário tetraédrico e estabilização de O- pela interação com dois grupos -NH. (3) O complexo acil-enzima é formado e, em seguida, sofre ataque nucleofílico por uma molécula de água (hidrólise) ou outro aceptor (transesterificação). (4) A liberação do produto e o local catalítico é restaurado. Adaptado de PÉREZ et al. (2018).

Devido a sua capacidade de agir sobre ésteres de ácidos graxos de cadeia longa, e suas diversas vantagens comerciais, as lipases despertam o interesse comercial e biotecnológico. Atualmente, as lipases são utilizadas pelas indústrias farmacêuticas, agroquímicas, alimentos, têxtil, biodiesel, cosmética, tratamentos ambientais, entre outras (GUPTA, 2004; MACHADO, 2013; ROSA et al., 2009).

O grande potencial biocatalítico da lipase obtida de microrganismos despertou o interesse industrial e hoje a reação hidrolítica enzimática é utilizada em diversos setores industriais, por exemplo, na indústria alimentícia para melhorar aromas, sabores, nutrição e promover a redução do índice de gordura; na produção de detergentes; sabões em pó e na indústria papeleira e de couro; produção de biocombustíveis, entre outros (HASAN et al., 2006; SAXENA et al., 1999). Portanto, é possível afirmar a grande versatilidade do 
uso da lipase, podendo sua catálise ser utilizada em diversos segmentos industriais, trazendo benefícios para uma produção em larga escala e, em adição, trazendo benefícios para a população.

\subsubsection{Lipases fúngicas}

Os microrganismos conhecidos por sua capacidade de secretar a lipase, são os principais produtores de enzimas utilizados no meio industrial para uso em aplicações biotecnológicas e químicas. Lipases de microrganismos são preferidas aos de fonte animal e vegetal por serem produzidas em menor tempo, as condições necessárias de crescimento dos microrganismos são mais facilmente controladas em laboratório e menos dispendiosas; além de possibilitarem a manipulação genética para expressão de enzimas e aumentando a eficiência catalítica destas, tornando-as mais viáveis para a indústria economicamente (SINGH, MUKHOPADHYAY, 2012).

Os fungos filamentos são considerados ótimos produtores de enzima, produzem a lipase extracelularmente de forma não patogênica e são de fácil manuseio laboratorial. Em adição, podem ser encontrados em diversos ecossistemas, possuem diversidade metabólica, rápido crescimento em condições facilmente controladas e os meios de cultivo necessitam de simples composições, como: fonte de carbono, calor, umidade e areação do meio de cultivo.

Podem ser denominados como fungos mesófilos ou termófilos, de acordo com a sua temperatura ótima de crescimento; sendo em torno de $25^{\circ} \mathrm{C}$ a $40^{\circ} \mathrm{C}$ para os fungos mesófilos e $50^{\circ} \mathrm{C}$ a $60^{\circ} \mathrm{C}$ para os fungos termófilos (MAGALHÃES, 2014; VICI, 2010; TREVISAN, 2004). Vários gêneros de microrganismos podem ser usados para produzir lipases, como fungos dos gêneros Trichosporon, Botrytis, Pichia, Fusarium, Aspergillus, Mucor, Rhizopus, Penicillium, Geotrichum, Tulopis e Candida (FABER, 2004; SARMAH et al., 2018).

Os fungos filamentosos, por serem microrganismos eucariontes, dispõem de estruturas celulares que possibilitam a secreção de suas enzimas e outros metabólitos para o meio extracelular, facilitando a identificação e purificação dessas enzimas (TREVISAN, 2004). A técnica de fermentação submersa utilizada para o crescimento fúngico e indução da produção de lipase consiste na dissolução do substrato que fica dissolvido ou suspenso no líquido, geralmente composto de água entre 90 a 99\% da massa 
total do material a ser fermentado. Através desta técnica é possível promover a produção das enzimas pelos fungos filamentosos selecionados, permitindo fácil acompanhamento da formação do produto e consumo do substrato, além do controle do $\mathrm{pH}$, temperatura, crescimento celular, oxigenação e esterilidade (MITCHELL et al., 2000).

Embora já existam várias lipases comercialmente disponíveis, o potencial de aplicação de novas enzimas, com características particulares, em diferentes ramos da atividade industrial é enorme. Nesse contexto, a aplicação intensa de lipases, no futuro, depende da identificação de novas enzimas, com características particularmente desejáveis em relação à seletividade de substrato, termoestabilidade, $\mathrm{pH}$ ótimo de reação, entre outros. Apenas cerca de 2\% dos microrganismos encontrados na natureza já foram testados como fontes de enzimas (HASAN et al., 2006).

Em relação à produção de biodiesel que ocorre através da reação de transesterificação, as lipases fúngicas são possíveis substituintes para os catalisadores químicos atualmente utilizados (NARWAL et al., 2013; HASAN et al., 2006). De acordo com Al-Zuhair et al. (2009), as lipases obtidas de fungos filamentosos possuem uma atividade melhor na reação de transesterificação, quando comparada às lipases obtidas de bactérias. A utilização das lipases que possuem um alto grau de especificidade como catalisadores para a produção do biodiesel auxilia na promoção de reações com maior velocidade e em condições suaves de temperatura e $\mathrm{pH}$, facilitando a condução das reações necessárias para a produção de biodiesel.

\subsection{Reação de Hidrólise a partir de óleos vegetais para a obtenção de ácidos graxos poli-insaturados}

Os ácidos graxos poli-insaturados (PUFAs) também conhecidos como "gordura boa" são essenciais na dieta humana, pois são responsáveis pelo bom funcionamento do organismo, atuando no equilíbrio homeostático e na composição das membranas celulares dos tecidos nervosos. Os ácidos graxos essenciais não são sintetizados pelo organismo, sendo necessário obtê-los através da alimentação (SALDANHA, GONZALES, 2012).

Existem dois grupos principais de ácidos graxos essenciais, o ácido linolênico (ômega-6) e o ácido linoleico (ômega-3). A maioria dos alimentos presentes na dieta humana não apresenta os ácidos graxos essenciais, desta maneira é necessário encontrar formas eficientes de extraí-los e incluí-los nos alimentos comumente ingeridos pela 
população. PUFAs possuem importante atuação no metabolismo de lipoproteínas, síntese de eicosanóides e funcionamento das plaquetas e das paredes dos vasos (DYEBERG et al., 1978). Alguns trabalhos demonstram que o consumo de PUFAs auxilia a diminuição de riscos de doenças graves como câncer no estômago. (LARSSON et al., 2004)

Os PUFAs podem ser obtidos através da reação de hidrólise de óleos vegetais, reação esta conduzida pelas lipases. Devido à alta especificidade de muitas lipases por determinados tipos de ácidos graxos, essas enzimas podem ser aplicadas na produção de concentrados de ácidos graxos poli-insaturados de óleos naturais, após reação de hidrólise; ou ésteres graxos poli-insaturados de gorduras derivadas, em reações de síntese (AGGELIS et al., 1995). Na indústria alimentícia as lipases são utilizadas para enriquecer alimentos com PUFAs. Em adição, PUFAs podem ser utilizados na indústria farmacêutica, para aplicação na síntese de medicamento como: anti-inflamatórios, trombolíticos e medicamentos destinados para perda de peso (PÉREZ et al., 2019).

Para as reações de hidrólise podem ser utilizados diversos óleos vegetais, tais como: óleo de açaí, óleo de buriti, óleo de girassol, óleo de soja, óleo de castanha do Brasil e óleo de pequi. A composição de ácidos oleicos e linoleicos de alguns óleos vegetais pode ser visualizada na Tabela 1.

Tabela 1. Concentração aproximada de ácidos graxos oleico (C18:1) e linoleico (18:2) dos óleos vegetais selecionados.

\begin{tabular}{cccccccccc}
\hline $\begin{array}{c}\text { Ácidos } \\
\text { graxos } \\
(\%)\end{array}$ & Açaí $^{1}$ & Buriti $^{2}$ & Girassol $^{3}$ & Soja $^{4}$ & $\begin{array}{c}\text { Castanha } \\
\text { do Brasil }\end{array}$ & Pequi $^{5}$ & Ojon $^{6}$ & Pracaxi $^{2}$ & $\begin{array}{c}\text { Manteiga } \\
\text { de } \\
\text { Tucumã }\end{array}$ \\
\hline $\begin{array}{c}\text { C18:1 } \\
\text { Oleico }\end{array}$ & 60 & 70,55 & 14,6 & 22,57 & 45,0 & 53,9 & 40,0 & 56,0 & 68,0 \\
$\begin{array}{c}\text { C18:2 } \\
\text { Linoleico }\end{array}$ & 12 & 7,03 & 73,9 & 48,11 & 38,0 & 1,5 & 15,0 & 11,0 & 3,0 \\
\hline
\end{tabular}

Fontes: 1 Nascimento (2008); 2 AmazonOil (2018); 3 Pighinelli (2009); 4 Aued-Pimentel (2009); 5 Facioli (1998); 6 AmazonForestTrading (2018).

O óleo de açaí (Euterpe oleracea) possui teor de ácidos graxos insaturados de $72 \%$, sendo bastante atrativo para o mercado de alimentos funcionais e também para a produção de biocombustível (NASCIMENTO, 2008). Em adição, o óleo extraído do buriti (Mauritia flexuosa) apresenta aproximadamente 78\% de ácidos graxos insaturados 
(AMAZONOIL, 2018). Tornando estes óleos interessantes para a utilização nas reações enzimáticas de hidrólise e transesterificação, capazes de produzir produtos biotecnológicos importantes.

Os óleos vegetais nativos açaí, macaúba, pequi, buriti, ojon, entre outros, podem ser utilizados como objetos de estudo para a produção de biodiesel através da transesterificação enzimática, por possuir características físico-químicas interessantes para o seu uso na produção de biodiesel, como também podem ser utilizados para a obtenção de ácidos graxos essenciais através da reação de hidrólise. Além disso, a inclusão do uso desses óleos na matriz energética brasileira pode incentivar a agricultura familiar sustentável de diversas regiões do país.

\subsection{Biodiesel}

O aumento da população mundial desencadeou uma grande demanda de energia. Em 2015, a Agência Nacional do Petróleo Gás Natural e Biocombustível (ANP, 2016) apresentou dados mostrando que em relação a 2014, a produção mundial de petróleo teve um crescimento de $3,2 \%$ e o consumo do petróleo neste mesmo período teve um aumento de 2\% (ANP, 2016). Em adição, devido ao crescimento do consumo de combustíveis fósseis, há uma grande quantidade de emissão dos gases poluentes para a atmosfera. Despertando a necessidade pela busca por combustíveis renováveis, que não agridam o meio ambiente.

O biodiesel é definido pela "National Biodiesel Board" (Estados Unidos) quimicamente como um éster monoalquílico de ácidos graxos, uma mistura de ésteres metílicos/etílicos de ácidos graxo (sigla em inglês: FAME), produzido pela reação de transesterificação de óleos vegetais ou gorduras animais (NARWAL; GUPTA, 2013). É considerado uma fonte de energia renovável e ecologicamente correta, tornando-o uma alternativa viável para a substituição ao uso de combustíveis fósseis (ANP, 2016).

O biodiesel foi introduzido na matriz energética brasileira em 13 janeiro de 2005, e em 2010, com a produção de 3,9 bilhões de litro tornando-se o segundo maior produtor de biodiesel do mundo (MELO, 2012; BIODIESELBR, 2014). De acordo com a Agência Nacional do Petróleo - ANP (2016): “Juntos, etanol e biodiesel fortalecem a participação dos biocombustíveis na matriz energética nacional e a imagem do Brasil como país que valoriza a diversidade de fontes energéticas". 
Os triglicerídeos utilizados para a síntese dos ésteres etílicos e metílicos, podem ser geralmente óleos vegetais extraídos de oleaginosas como: soja, girassol, milho, algodão, canola, amendoim e mamona, além de óleos extraídos de vegetações regionais como: macaúba, pequi, dendê e babaçu. A composição de ácidos oleicos e linoleicos do óleo vegetal auxilia na eficiência da reação de transesterificação, onde a composição destes ácidos, auxilia na maior produção de biodiesel (BELTRÃO, OLIVEIRA, 2008). A gordura animal também pode ser utilizada como matéria-prima para a síntese do biodiesel. O Brasil possui como vantagens a sua geografia, grande disponibilidade hídrica e clima tropical favorável para cultivo de espécies vegetais que possam ser utilizadas para a produção de biodiesel; tais como: girassol, castanha, soja, macaúba, entre outros (BIODIESELBR, 2014). O biodiesel pode ser obtido em larga escala através de reações de transesterificações, esterificações e reações enzimáticas via catálise homogênea e heterogênea básica e ou ácida. Em adição, as lipases são um biocatalisador potencial e muito eficiente sendo utilizadas na catálise enzimática para a produção de biodiesel (NOUREDDINI et al., 2005; DU et al., 2004; OLIVEIRA et al., 2004)

Atualmente, o uso comercial do biodiesel obtido do óleo vegetal utilizando catalisadores químicos é feito através da sua mistura com o diesel convencional, pois devido a uma alta viscosidade e a formação de ácidos graxos livres, o uso direto do biodiesel a longo prazo pode causar problemas ao motor como: depósito de carbono e oxidação. O método mais popular de produzir o biodiesel em larga escala é através da reação de transesterificação. Outros métodos também são aplicados: esterificação, pirólise e micro-emulsificação. Em sua grande maioria estas reações são conduzidas com auxílio de catalisadores químicos, que apresentam desvantagens ambientais. Desta maneira, a catálise enzimática da reação de transesterificação acaba se tornando atrativa para a produção do biodiesel, por não utilizar substratos ou reagentes com alta toxicidade (FACCHINI, et al., 2016; PÉREZ et al., 2019; RANGANATHAN et al., 2008).

\subsubsection{Reação de transesterificação}

O método mais popular de produzir o biodiesel é através da reação de transesterificação, que é a etapa da conversão propriamente dita do óleo vegetal, em ésteres metílicos ou etílicos de ácidos graxos, que constitui o biodiesel. A reação de transesterificação, é conduzida na presença de um álcool e um catalisador, promovendo 
a conversão de triglicerídeos em dois produtos: éster monoalquílico de ácidos graxos (biodiesel) e glicerol, conforme visto na Figura 5. O processo é composto de reações reversíveis, formando como intermediários o diacilglicerídeos e monoacilglicerídeos. A reação ocorre na razão estequiométrica de três mols de álcool para um mol de triglicerídeos. Resultando em três ésteres de ácido graxo, para cada molécula de triglicerídeo (GHALY et al., 2010).

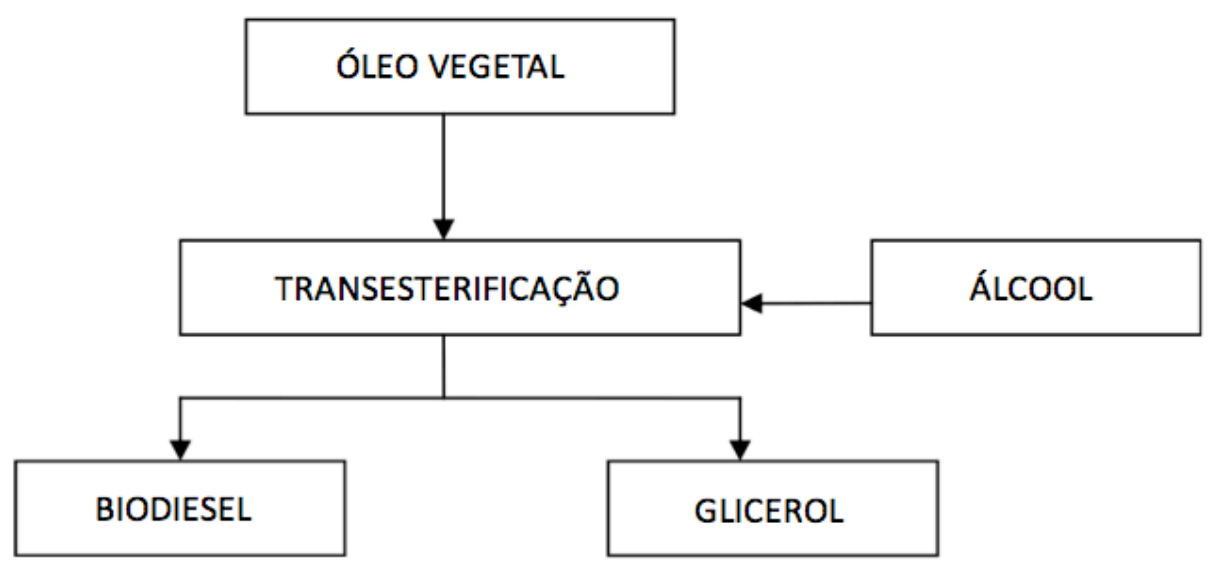

Figura 5. Esquema de processo e formação de produtos da reação de transesterificação a partir de óleos vegetais. Adaptado de RANGANATHAN et al. (2008).

O metanol e o etanol são os álcoois de cadeia curta mais utilizados para a reação de transesterificação (NARWAL; GUPTA, 2013). A reação do triglicerídeo com metanol resulta em ésteres metílicos, já a reação envolvendo o etanol resulta em ésteres etílicos. Vários outros álcoois podem ser utilizados para a reação, como o propanol e o butanol.

\subsubsection{Transesterificação alcalina e ácida}

A transesterificação alcalina é um método industrial bastante popular e como catalisadores comuns são utilizados o hidróxido de sódio $(\mathrm{NaOH})$ e o hidróxido de potássio $(\mathrm{KOH})$. Para a reação alcalina ocorrer é necessário que o óleo vegetal passe por um pré-tratamento, para a quantidade de água e ácidos graxos livres serem reduzidos, com a finalidade de prevenir a ocorrência de reações entre o catalisador e os ácidos graxos livres, resultando na formação de sabão que interferirá na condução da reação, promovendo uma subtração do rendimento final da reação. Em adição, neste processo há a dificuldade de separação do biodiesel e do glicerol formado (MENEGHETTI et al., 
2013). Portanto, o biodiesel deve passar por vários processos de limpeza para que o catalisador, o sabão e o álcool em excesso sejam retirados e seja alcançado o nível de pureza desejado (RANGANATHAN et al., 2008).

$\mathrm{Na}$ transesterificação ácida, os catalisadores comuns são o ácido sulfúrico e o ácido sulfônico. A catálise ácida é indicada para óleos com alto teor de ácidos graxos livres, como o óleo de fritura (MACHADO, 2013). Porém, esta catálise possui como grande desvantagem o risco de corrosão do equipamento industrial, alto aquecimento dos equipamentos envolvidos e baixo rendimento, quando comparado à catálise básica (MENEGHETTI et al., 2013).

\subsubsection{Transesterificação enzimática}

As enzimas são catalisadores biológicos com comprovada eficiência, possuem alto grau de especificidade e diversidade quanto as soluções onde possam atuar, entre outras diversas vantagens reacionais (GAMBA, 2009). A catálise enzimática para a reação de transesterificação tem ganhado destaque por promover vantagens para o processo. Algumas dessas vantagens são: (a) a reação requer temperaturas amenas para ocorrer, (b) ao final da reação a catálise enzimática facilita a recuperação do glicerol e separação do biodiesel, (c) não requer pré-tratamento do óleo vegetal utilizado para a reação e (d) ao estar imobilizada, a enzima pode ser reciclada com eficiência. Em adição, a reação de transesterificação através da catálise enzimática não é prejudicada pela presença de ácidos graxo livres, como ocorre na catálise básica e ácida, pois todo os ácidos graxos livres são convertidos em ésteres monoalquílicos (reação de esterificação), proporcionando um maior rendimento para a reação (MACEDO; MACEDO, 2004). enzima utilizada para a transesterificação enzimática é a lipase, podendo ser extraídas dos meios intracelulares ou extracelulares de microrganismos (RANGANATHAN et al., 2008).

Fatores físico-químicos interferem na reação de transesterificação enzimática, consequentemente interferindo no rendimento final da produção do biodiesel. Exemplos de alguns destes fatores são: proporção álcool/óleo, temperatura, umidade e quantidade de solventes orgânicos. Apesar da transesterificação alcalina ter um rendimento de aproximadamente 99\% (GERPEN, 2005), a transesterificação enzimática por ser um método ecológico, com alta produtividade e capaz de proporcionar uma maior facilidade 
de separação dos produtos finais, se torna um interessante substituto à reação de transesterificação alcalina no meio industrial. O rendimento da transesterificação pode ser otimizado, proporcionando melhores resultados, à medida que novos estudos são conduzidos e divulgados na literatura.

A produção em larga escala de biodiesel utilizando enzimas de microrganismos presentes em nosso ecossistema e óleos vegetais nativos podem se tornar parte da solução para os problemas ambientais causados pelo uso de combustíveis fósseis, além de contribuir na demanda energética mundial e também incentivar pequenos produtores agrícolas.

Devido ao impacto ambiental causado pelo uso de combustíveis fosseis, a busca por alternativas ecológicas, como o uso de biocombustíveis, ganha cada vez mais destaque. O Brasil é considerado um grande produtor mundial de álcool etílico, com diversas usinas espalhadas pelo país (RODRIGUES, 2007). O Brasil soma diversas vantagens para a produção de biodiesel, como a vasta variedade de óleos vegetais produzidos em todo território nacional e que podem ser utilizados. Em adição, o etanol pode ser utilizado em substituição ao metanol (origem fóssil). Entretanto, para que essa fonte de energia seja mais ecologicamente viável, é necessário o aprimoramento de tecnologias de produção desse biocombustível através da transesterificação enzimática, substituindo os catalisadores químicos atualmente utilizados.

\subsection{Imobilização enzimática}

Com a finalidade de aproveitar o potencial catalítico das enzimas e reunir as vantagens dessas proteínas sobre os catalisadores químicos, tem-se estudado formas de torná-las insolúveis ao meio reacional. A imobilização de enzimas tem papel importante nas aplicações biotecnológicas. A imobilização da proteína em suportes insolúveis, além de facilitar sua recuperação, pode também ajudar a estabilizar a estrutura da enzima, reduzindo assim a inativação do biocatalisador, seja térmica ou devido a interações com solventes. A escolha do método mais adequado de imobilização deve ser baseada em diferentes critérios, tais como a máxima atividade da enzima imobilizada, estabilidade bioquímica, custos de imobilização e a toxicidade de imobilização de reagentes (MENDES et al., 2010; SOUZA et al., 2017).

Para a utilização da catálise enzimática em reações de escala industrial, a 
imobilização enzimática torna-se uma estratégica interessante, pois esta técnica favorece a reutilização da enzima - reduzindo o impacto do seu alto custo de aquisição - e facilita o controle do processo. Por outro lado, enzimas livres solúveis, ao serem utilizadas para a reação, podem ser mais facilmente inativadas devido ao efeito do solvente ou em razão dos choques mecânicos, diminuindo sua estabilidade operacional (MENDES et al., 2013). Tais características das enzimas imobilizadas são bastante atraentes para aplicações industriais, melhorando as técnicas já utilizadas no mercado industrial para produção de produtos de hidrólise e da reação de transesterificação.

Desta maneira, as enzimas imobilizadas possuem um grande potencial para substituir os catalisadores químicos na produção industrial de biodiesel (RANGANATHAN et al., 2008). Para que a lipase seja utilizada de maneira eficiente, ela deve ser imobilizada em suportes insolúveis e específicos, aumentando a sua estabilidade e evitando a sua inativação durante o processo e por fim, facilitando a sua reciclagem.

Na Tabela 2 é possível verificar as diferentes características do uso das enzimas livres e imobilizadas para as reações.

Tabela 2. Comparação de algumas características de enzima livres e enzimas imobilizadas.

\begin{tabular}{c|c}
\hline Enzima livre & Enzima imobilizada \\
\hline Dificuldade de recuperação e reutilização & Fácil separação do produto e capacidade de \\
Alto custo, baixa eficiência e insolúvel em meio & reuso \\
não aquoso & Alta eficiência \\
Atividade instável, influenciada pela & \\
temperatura e pH & Atividade estável em uma ampla faixa de \\
& temperatura e pH \\
\hline
\end{tabular}

Fonte: (ZHANG et al., 2012).

Vários suportes podem ser utilizados para promover a imobilização das enzimas, aplicando técnicas já conhecidas como: encapsulamento, adsorção em suportes porosos, ligação covalentes, interações hidrofóbicas, entre outras. A análise destes critérios facilita a descoberta de uma imobilização eficiente, de maneira que haja uma melhor resposta da enzima para a reação específica a ser aplicada (YAN et al., 2013; MENDES et al., 2010).

As lipases precisam ser vigorosas e versáteis devido a gama de substratos nos 
quais podem atuar, portanto devem apresentar uma alta especificidade (GUPTA et al., 2003). Neste contexto, as características bioquímicas da lipase, como a estabilidade térmica e ao $\mathrm{pH}$ precisam ser otimizadas. Quando a enzima é imobilizada, é possível observar uma modificação na sua estabilidade, quando comparada a enzima livre. Dessa forma, o uso de enzimas imobilizadas torna-se mais atraente, uma vez que a instabilidade e a impossibilidade de reutilização de uma enzima são obstáculos para as indústrias que podem ser ultrapassados através desta técnica, aumentando a eficiência das enzimas (FERNANDEZ-LORENTE et al., 2008).

Na literatura, observa-se a imobilização das lipases em diferentes suportes de natureza orgânica e inorgânica, empregando diferentes métodos de imobilização, como: adsorção física ou hidrofóbica, confinamento em matrizes poliméricas, encapsulamento, ligação covalente, entre outros. Após a enzima se ligar ao suporte, esta passa a ser chamada de derivado (MATEO et al., 2002; MATEO et al., 2007; FERNANDEZLORENTE et al., 2011).

Os suportes hidrofóbicos são os mais empregados em lipases, pois exploram a existência da superfície hidrofóbica nas "tampas" (MANOEL et al., 2015), proporcionando interações fracas com as cadeias alifáticas ou aromáticas apolares nestes suportes; os suportes com grupos como Phenyl, Butyl (4 carbonos) Octyl (8 carbonos) e Octadecyl (18 carbonos), são exemplos de suportes hidrofóbicos que podem ser utilizados na técnica de imobilização de lipases. Todavia, tais interações hidrofóbicas não são restritas apenas à “tampa”, mas qualquer superfície hidrofóbica presente na enzima. Uma característica muito comum, mas não obrigatória, neste tipo de imobilização é a hiperativação: fenômeno decorrente do deslocamento da "tampa" após imobilização, expondo o sítio ativo ao meio reacional, resultando em aumento potencial da atividade enzimática (MANOEL et al., 2015; FACCHINI, 2014).

Um campo também explorado na imobilização de lipases é a utilização de polímeros. O PEI (polietilenoimina) pode ser utilizado tanto para imobilizar enzimas (em um suporte de agarose, por exemplo) ou revesti-las após imobilização em outro suporte (ZHANG; ROCHEFORT, 2011).

Resinas de troca iônica são também bastante utilizadas para imobilização enzimática, pois permite rápido isolamento de proteínas em $\mathrm{pHs}$ brandos. As resinas de interação iônica podem ser trocadores aniônicos ou catiônicos. Desse modo, a presença 
de cargas na superfície da enzima é importante para ligação à resina, a qual depende principalmente do $\mathrm{pH}$ do meio e da sequência primária da proteína (DATTA et al., 2013). Nos estudos de interação iônica, os suportes monoamino-N-aminoetil (MANAE) agarose e Duolite são bastante empregados.

MANAE agarose apresenta resíduos nitrogenados carregados positivamente ligados à agarose. Duolite A568 é uma resina de troca aniônica, fracamente básica, granular, altamente porosa e com estrutura hidrofílica. Estas características tornam esta resina mais adequada para ser utilizada como suporte para imobilização de enzimas em muitos bioprocessos, e visam otimizar a imobilização de enzimas, podendo ter potencial utilização no mercado de biocombustíveis (KREMER, 2007; SOUZA et al., 2017).

Em estudos realizados no Laboratório de Microbiologia/Biologia Celular da Faculdade de Filosofia, Ciências e Letras de Ribeirão Preto, USP, sob orientação da Profa. Dra. Maria de Lourdes T. M. Polizeli, os suportes hidrofóbicos Octyl-sepharose e Sepabeads C-18 e os suportes iônicos MANAE-agarose, Q-sepharose, DEAE-agarose e Duolite, foram utilizados em lipases extraídas dos fungos filamentos Hypocrea pseudokoningii, Fusarium verticillioides e Beauveria bassiana (PEREIRA, et al., 2015; FACCHINI, 2014 e VICI, 2015). Os resultados demonstraram alta eficiência de imobilização e atividade enzimática melhorada.

De acordo com PEREIRA et al. 2015, a lipase imobilizada adquiriu uma maior estabilidade térmica e alta estabilização em solventes orgânicos, que podem ser verificados através da análise de $\mathrm{t}_{50}$ que denota o tempo em que $50 \%$ da atividade proteica mantém-se em solução (CHAPLIN; BUCKE, 1990). Em adição, imobilização permite a fácil reciclagem da enzima. Tais características são bastante atraentes para aplicações industriais, melhorando as técnicas já utilizadas no mercado industrial para produção de produtos de hidrólise e da reação de transesterificação. 
II-OBJETIVOS 


\subsection{Objetivo Geral}

Identificar os melhores produtores fúngicos de lipases com capacidade de transesterificação e hidrólise eficientes, selecionados da Micoteca da Faculdade de Filosofia, Ciências e Letras de Ribeirão Preto - USP, no Laboratório de Microbiologia e Biologia Celular. Além disso, estudar as lipases na forma livre e imobilizada em suportes hidrofóbicos e iônicos, verificando a eficiência da imobilização, com o objetivo de sintetizar produtos para aplicações biotecnológicas.

\subsection{Objetivos Específicos}

1. Realizar um screening de fungos filamentosos produtores de lipase obtidos na Micoteca da Faculdade de Filosofia, Ciências e Letras de Ribeirão Preto - USP, no Laboratório de Microbiologia e Biologia Celular;

2. Produzir lipases dos fungos selecionados através do cultivo em fermentação submersa, seguido de análises de otimização e padronização das características de cultivo;

3. Imobilizar as lipases nos suportes hidrofóbicos Octyl-sepharose, Butyl-sepharose e Sepabeads C-18 e nos suportes iônicos PEI-agarose, MANAE-agarose e Duolite, avaliando sua eficiência;

4. Identificar o melhor método de uso (livre ou imobilizada) da lipase para aplicações nas reações de transesterificação e hidrólise;

5. Promover e avaliar as reações de transesterificação e hidrólise de diferentes óleos vegetais, utilizando a lipase fúngica;

6. Determinar características físico-químicas do produto da reação de transesterificação enzimática. 


\section{III-MATERIAIS E}

MÉTODOS 


\subsection{Screening dos fungos produtores de lipase}

Foram selecionados 11 fungos produtores de lipases pertencentes a Micoteca do Laboratório de Microbiologia e Biologia Celular do Departamento de Biologia da FFCLRP/USP, a qual encontra-se sob responsabilidade da Prof ${ }^{a}$ Dra. Maria de Lourdes T. M. Polizeli. Os gêneros de fungos filamentosos selecionados foram: Humicola, Aspergillus, Trichoderma, Penicillium e Scytalidium. A manutenção dos fungos foi feita em tubos estéreis contendo $10 \mathrm{~mL}$ de meio de aveia sólido (Anexo I) previamente autoclavados por 20 minutos, $1,5 \mathrm{~atm}$ a $127^{\circ} \mathrm{C}$ e inclinados.

Estes foram mantidos em temperaturas de $30{ }^{\circ} \mathrm{C}$ e $40{ }^{\circ} \mathrm{C}$, respeitando as temperaturas dos mesófilos e termófilos. O crescimento dos fungos nos tubos estéreis foi mantido por 4 dias. Foram realizados repiques periódicos nas mesmas condições, mantendo as cepas em estufa até o crescimento satisfatório. Após o tempo determinado, os fungos foram armazenados em refrigerador a $4^{\circ} \mathrm{C}$.

Para a análise de produção de lipase e pré-seleção dos 11 fungos, foi utilizado o método de hidrólise de tributirina em placa. As culturas fúngicas foram inoculadas em placas de Petri contendo meio de cultura SR com adição de 2 g de ágar bacteriológico (Anexo I) (RIZZATTI et al., 2001), suplementado com tributirina 1\% como fonte de carbono, seguida da incubação em estufa a $30{ }^{\circ} \mathrm{C}$ e $40{ }^{\circ} \mathrm{C}$, respeitando as temperaturas dos fungos mesófilos e termófilos, por 72 horas. Posteriormente, as placas foram coradas com o corante Victoria Blue $(0,01 \% \mathrm{~m} / \mathrm{v})$ para visualização da produção de lipase que é evidenciada através da formação de halos de coloração azul escuro. Antes da coloração é possível visualizar os mesmos halos como uma zona clara em torno das culturas.

As culturas fúngicas que apresentaram melhor área de hidrólise, ou seja, um halo com tamanho favorável $(\mathrm{cm})$, medidos em relação à medição da cultura formada $(\mathrm{cm})$, foram selecionadas para subsequente cultivo em meio fermentativo líquido, para a indução da produção de lipases.

\subsection{Obtenção das culturas em fermentação submersa}

A fim de fazer a seleção final dos melhores fungos produtores de lipase, os fungos selecionados a partir do screening em placa de Petri foram submetidos a técnica de fermentação submersa e subsequente ensaios de dosagem enzimática. 
A fermentação submersa foi realizada de acordo com a metodologia de Facchini et al. (2016) e Vici (2015) e o meio SR (RIZZATTI et al., 2001) foi designado inicialmente como meio de cultivo padrão.

Para obtenção das culturas foi realizado o inóculo de 1,0 mL de uma solução com $10^{7}$ esporos. $\mathrm{mL}^{-1}$ ressuspensos em água destilada esterilizada, em meio de cultura SR líquido. Foram adicionados $25 \mathrm{~mL}$ de meio SR líquido em frascos Erlenmeyer de 125 $\mathrm{mL}$, suplementados com $1 \%$ de óleo de soja comercial como fonte de carbono. Previamente ao inóculo, os meios líquidos foram autoclavados por 20 minutos a 1,5 atm, em temperatura de $127^{\circ} \mathrm{C}$. Os meios inoculados foram incubados a $30{ }^{\circ} \mathrm{C}$ ou $40{ }^{\circ} \mathrm{C}$, respeitando as temperaturas dos fungos mesófilos e termófilos, sob agitação orbital de $120 \mathrm{rpm}$, por 7 dias.

Durante o período de crescimento fúngico, alíquotas de $500 \mu \mathrm{L}$ foram retiradas periodicamente para ensaio de detecção da atividade de lipase. Após o período de fermentação a cultura foi filtrada a vácuo, utilizando papel Whatman $n^{\circ} 1$, funil de Büchner e frasco de Kitassato. O material filtrado foi armazenado em tubos cônicos de 50 mL e mantido em gelo para posterior determinação da atividade lipolítica extracelular. O material retido no papel Whatman $\mathrm{n}^{\mathrm{o}} 1$, determinado como massa micelial ou micélio, foi armazenado em refrigerador a $4^{\circ} \mathrm{C}$.

\subsection{Ensaio de atividade de lipase}

Lipases atuam sobre o substrato sintético $p$-nitrofenilpalmitato (pNPP - Sigma Aldrich) liberando o $p$-nitrofenol e ácido palmítico. Em pH alcalino, o $p$-nitrofenol é convertido em $p$-nitrofenolato ( $\mathrm{pNP}$ ), apresentando uma coloração amarela, com máxima absorção a 405-410 nm. Esse método é ideal e simples para verificar a presença desta enzima no extrato e o efeito de moléculas exógenas (como íons, ácidos graxos, solventes) ou condições do meio aquoso ( $\mathrm{pH}$ e temperatura) sobre a atividade de lipases (PENCREAC'H; BARATTI, 1996).

Para todas as análises de atividade enzimática do presente trabalho, foi utilizado o método de Pencreac'h; Baratti (1996), que utiliza o pNPP como substrato para a reação de hidrólise.

Todas as reações de hidrólise do pNPP foram conduzidas por 10 mininutos. As 
condições para esta metodologia foram padronizadas de acordo com o descrito no Anexo II e diferentes temperaturas foram testadas, em um faixa de $30{ }^{\circ} \mathrm{C}$ a $60{ }^{\circ} \mathrm{C}$, para determinação da melhor temperatura de dosagem para a lipase produzida pelos fungos filamentosos selecionados. A reação foi interrompida pela adição de solução saturada de tetraborato de sódio $\left(\mathrm{Na}_{2} \mathrm{~B}_{4} \mathrm{O}_{7}\right)$, na proporção 1:1. O pNP liberado por hidrólise, foi quantificado em espectrofotômetro a $405 \mathrm{~nm}$, utilizando placas de leitura de 96 poços. Controles com adição de enzimas desnaturadas foram incluídos em cada experimento.

A unidade (U) está definida como sendo a quantidade de enzima necessária para hidrolisar um $\mu \mathrm{mol}$ do substrato em um minuto ( $\mu \mathrm{mols} / \mathrm{min}$ ), nas condições de ensaio e a atividade específica em $\mathrm{U} . \mathrm{mg}^{-1}$ de proteína.

\subsection{Teste de viabilidade dos micélios}

O micélio obtido após a filtração da cultura (Figura 6) foi lavado em água deionizada e pesado para obtenção da massa úmida. Posteriormente foi preparado para a dosagem de lipases intracelulares.

Para tanto, o micélio foi macerado com 2 volumes de areia previamente tratada com solução sulfonítrica - ácido sulfúrico:ácido nítrico (1:3) - em gral de porcelana, mantido em gelo. O macerado foi ressuspenso em $10 \mathrm{~mL}$ de água deionizada e o material foi então centrifugado a $8000 \mathrm{xg}$, durante 15 minutos, a $4^{\circ} \mathrm{C}$, para remoção da areia e dos debris celulares. O sobrenadante obtido - o extrato bruto intracelular - foi utilizado para a determinação da atividade lipolítica intracelular através da hidrólise do pNPP e para dosagem de proteínas. 


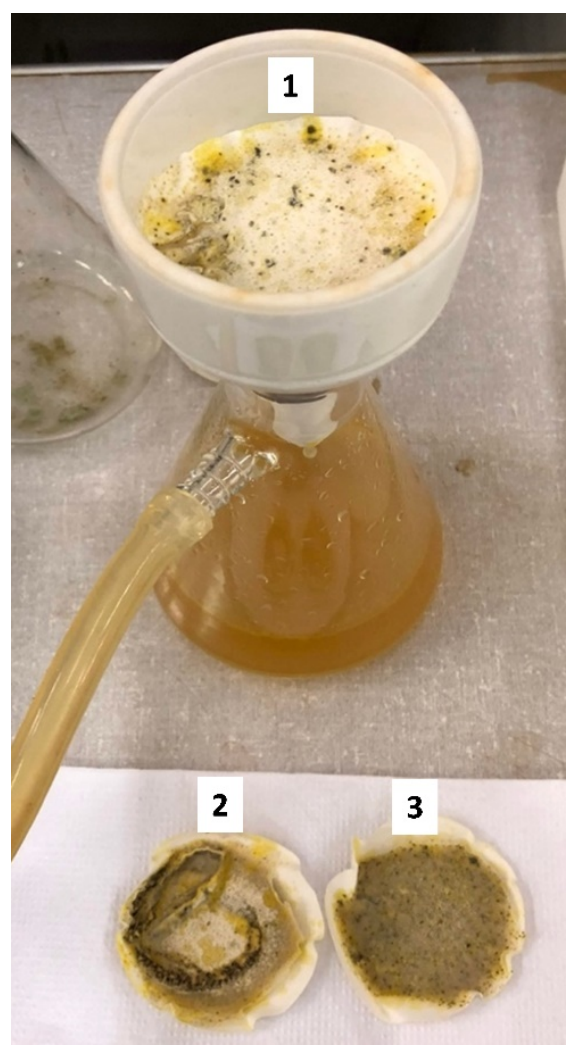

Figura 6. Filtração a vácuo do extrato bruto suplementado com $1 \%$ de óleo de soja, para obtenção dos micélios em papel Whatman $\mathbf{n}^{\mathbf{0}} 1$. Micélios obtidos do extrato bruto de (1) $H$. grisea (2) S. thermophilum e (3) A. phoenicis após 96 horas de cultivo nas temperaturas de $40^{\circ} \mathrm{C}$ para $H$. grisea e $S$. thermophilum e $30^{\circ} \mathrm{C}$ para $A$. phoenicis.

\subsection{Determinação de Proteínas}

Para análise da concentração de proteínas dos extratos obtidos foi realizado ensaios através do método de Lowry (LOWRY, 1951). Em tubos de ensaio, foram adicionados $60 \mu \mathrm{L}$ de amostra, $140 \mu \mathrm{L}$ de água destilada, $1 \mathrm{~mL}$ de solução de Lowry (Anexo III). A solução resultante foi incubada a temperatura ambiente por 15 minutos. Posteriormente, foram adicionados $100 \mu \mathrm{L}$ Folin-Ciocalteau em $\mathrm{H}_{2} \mathrm{O}$ (na proporção 1:1) e incubado a temperatura ambiente por 30 minutos.

Por fim foi feita a leitura em espectrofotômetro a $620 \mathrm{~nm}$. Uma curva padrão de Soro Albumina Bovina (BSA) como referência para análise dos dados.

A unidade proteica foi definida como $\mathrm{mg}$ de proteína/mL. A atividade específica da enzima foi calculada a partir da razão entre a atividade enzimática $(\mathrm{U} / \mathrm{mL})$ e a concentração de proteínas $(\mathrm{mg} / \mathrm{mL})$, resultando no valor de atividade específica expressa em $\mathrm{U} / \mathrm{mg}$ de proteína. 


\subsection{Otimização da produção de lipase}

Foram testados os meios nutrientes líquidos SR e Khanna (Anexo I) adicionados de $1 \%$ de óleo de soja comercial. A definição do melhor meio nutriente foi realizada através da análise de dosagem enzimática das alíquotas retiradas periodicamente, durante o crescimento fúngico por 7 dias.

Após definido o meio líquido de cultivo, foram testadas diferentes fontes de carbono de origem lipídica com concentração de 1\%: óleos de soja (Glycine max (L.) Merr), girassol (Helianthus annuus L.), buriti (Mauritia flexuosa), açaí (Euterpe oleracea), peixe e pequi (Caryocar brasiliense Camb). O cultivo ocorreu por até 96 horas. Os óleos selecionados foram obtidos de forma comercial no Mundo dos óleos ${ }^{\circledR}$.

Através das análises de dosagem enzimática das alíquotas retiradas periodicamente, foi possível determinar a melhor fonte de carbono de origem lipídica para o crescimento fúngico. Em adição, foi possível determinar o melhor tempo de para obtenção de lipases dos três fungos selecionados.

\subsection{Concentração de proteínas do extrato bruto por sulfato de amônio}

Com a finalidade de melhorar o acesso do substrato ao sítio ativo da enzima e eliminar componentes do meio de cultivo que poderiam influenciar na atividade enzimática, verificou-se a eficiência do método de precipitação de proteínas por sulfato de amônio, utilizando a metodologia de Basha et al. (2009). Para tanto, a $200 \mathrm{~mL}$ do extrato bruto obtido do fungo $S$. thermophilum e do fungo A. phoenicis, cultivados nas condições anteriormente determinadas, foi adicionado sulfato de amônio [ $\left.\left(\mathrm{NH}_{4}\right)_{2} \mathrm{SO}_{4}\right]$ para precipitação, nas concentrações de $35 \%$ e $50 \%$, seguido de incubação a $4^{\circ} \mathrm{C}$ por 24 horas. A amostra foi centrifugada a $7600 \mathrm{xg}, 4^{\circ} \mathrm{C}$ por 10 minutos. $\mathrm{O}$ precipitado obtido foi ressuspenso em $200 \mathrm{~mL}$ de tampão McIlvaine (McILVAINE, 1921) pH 7 e submetido a diálise, utilizando sacos de diálise, em tampão McIlvaine $\mathrm{pH} 7$, a $4^{\circ} \mathrm{C}$, por 24 horas. Após o período determinado, fez-se o teste de dosagem enzimática para verificar a eficiência deste método.

\subsection{Termoinativação da enzima livre}

A termoinativação da lipase livre foi avaliação incubando-se $500 \mu \mathrm{L}$ de extrato 
bruto adicionado de $500 \mu \mathrm{L}$ de tampão McIlvaine $\mathrm{pH}$ 6,0 nas temperaturas de $40{ }^{\circ} \mathrm{C}, 50$ ${ }^{\circ} \mathrm{C}, 60{ }^{\circ} \mathrm{C}, 70{ }^{\circ} \mathrm{C}$ e $80{ }^{\circ} \mathrm{C}$.

Alíquotas foram retiradas nos períodos de 0, 2, 4, 24 e 48 horas para dosagem enzimática com pNPP.

\subsection{Imobilização da lipase em suportes sólidos}

As lipases produzidas pelos fungos selecionados foram imobilizadas em suportes hidrofóbicos e iônicos. A imobilização em suportes hidrofóbicos ocorreu em matrizes comerciais Octyl- sepharose (GE - Healthcare), Butyl-sepharose (GE - Healthcare) e Sepabeads C-18 (GE - Healthcare). Os suportes de interação iônica utilizados foram MANAE-agarose, PEI-agarose e Duolite A568 (Rohm and Haas, USA), todos previamente preparados conforme manual do fabricante.

Para o experimento de imobilização, $1 \mathrm{~g}$ de suporte foi misturado a um volume de $38 \mathrm{~mL}$ de extrato bruto dos fungos selecionados e $2 \mathrm{~mL}$ de tampão fosfato de sódio 50 $\mathrm{mM}, \mathrm{pH} 7,0$. Essa mistura foi mantida em agitador de rolos a temperatura ambiente. Periodicamente, foram retiradas alíquotas de $0,5 \mathrm{~mL}$ da suspensão e do sobrenadante, e em seguida, submetidas a ensaios de atividade de lipases por hidrólise de pNPP 12 mM, em thermomixer a $50{ }^{\circ} \mathrm{C}$, por 10 minutos, $800 \mathrm{rpm}$, para análise da eficiência de imobilização.

O derivado (enzima imobilizada no suporte) foi separado do sobrenadante com auxílio de um filtro acoplado na ponteira da pipeta. Em vista do que foi descrito, o valor de atividade do derivado correspondeu à diferença entre o valor de atividade enzimática obtido da suspensão e do sobrenadante. Ao término de 24 horas de imobilização, os derivados foram filtrados, lavados com água destilada e armazenados a $4{ }^{\circ} \mathrm{C}$.

A unidade da atividade enzimática (U) foi definida como a liberação de $1 \mu \mathrm{mol}$ de p-nitrofenol (pNP) por minuto, por grama de derivado $(\mathrm{U} / \mathrm{g})$.

\subsection{Ensaios de estabilidade das lipases imobilizadas}

\subsubsection{Termoinativação dos derivados}

Para ensaios de termoinativação dos derivados obtidos para as lipases de $A$. phoenicis, foram analisados os biocatalisadores produzidos com os suportes Octyl- 
sepharose; Butyl-sepharose e Sepabeads C-18. Para as lipases do fungo S. thermophilum foram analisados os derivados obtidos dos suportes Octyl-sepharose; Sepabeads C-18 e Duolite. Os suportes foram selecionados a partir do experimento anterior. A termoinativação das lipases livres foi novamente analisada como um controle experimental. O objetivo desse experimento foi verificar a melhora ou não da estabilidade da enzima após a imobilização.

Para tal, foram preparadas suspensões com $40 \mathrm{mg}$ de cada derivado e $2 \mathrm{~mL}$ de tampão McIlvaine pH 6,0. O controle foi realizado com $1 \mathrm{~mL}$ de extrato bruto adicionados de $1 \mathrm{~mL}$ de tampão McIlvaine pH 6,0.

As soluções foram incubadas nas temperaturas de $40{ }^{\circ} \mathrm{C}, 50^{\circ} \mathrm{C}, 60^{\circ} \mathrm{C}, 70{ }^{\circ} \mathrm{C}$ e 80 ${ }^{\circ} \mathrm{C}$. Essas soluções foram incubadas por até 48 horas e, periodicamente, retirou-se alíquotas de $0,05 \mathrm{~mL}$ as quais foram utilizadas para a hidrólise de pNPP $12 \mathrm{mM}$, a $50^{\circ} \mathrm{C}$, por 10 minutos. Os períodos analisados foram 0, 1, 2, 3, 4, 24 e 48 horas. Os resultados foram expressos como atividade residual (em \%) obtida em relação à atividade quantificada no tempo zero para cada derivado e enzima livre. Em seguida, foram determinados os valores de $\mathrm{t}_{50}$.

\subsubsection{Estabilidade dos derivados a diferentes valores de $\mathrm{pH}$}

Verificou-se a estabilidade da enzima livre e imobilizada de ambos os fungos frente a diferentes valores de $\mathrm{pH}$. Para a lipase de $A$. phoenicis foram analisados os suportes: Octyl-sepharose; Butyl-sepharose e Sepabeads C-18; e para a lipase de $S$. thermophilum foram analisados os suportes: Octyl-sepharose, Sepabeads C-18 e Duolite. O objetivo desse experimento foi verificar a melhora ou não da estabilidade da enzima após a imobilização em diferentes pHs.

Para tal, foram preparadas suspensões com $40 \mathrm{mg}$ de cada derivado e $2 \mathrm{~mL}$ de tampão McIlvaine pH 6,0, 7 e 8 e em tampão glicina 200 mM, pH 9. O controle foi realizado com $1 \mathrm{~mL}$ de extrato bruto adicionados de $1 \mathrm{~mL}$ de tampão McIlvaine nos mesmos pHs.

As soluções foram incubadas a $40^{\circ} \mathrm{C}$ por até 48 horas. Periodicamente, retirou-se alíquotas de $0,05 \mathrm{~mL}$ as quais foram utilizadas para a hidrólise de pNPP $12 \mathrm{mM}$, a $50^{\circ} \mathrm{C}$, por 10 minutos. Os períodos analisados foram 0, 1, 2, 3, 4, 24 e 48 horas. Os resultados 
foram expressos como atividade residual (em \%) obtida em relação à atividade quantificada no tempo zero para cada derivado e enzima livre. Em seguida, foram determinados os valores de $\mathrm{t}_{50}$.

\subsubsection{Estabilidade dos derivados a solventes orgânicos}

Avaliou-se a estabilidade da enzima livre e imobilizada nos solventes orgânicos: ciclohexano, hexano, metanol, etanol e acetona. Os suportes selecionados foram Duolite e Sepabeads C-18 para a lipase de $S$. thermophilum e Octyl-sepharose para a lipase de $A$. phoenicis. Os solventes selecionados para o teste de estabilidade são utilizados nas reações de hidrólise e transesterificação.

Para tal, foram preparadas suspensões com $40 \mathrm{mg}$ de cada derivado e $1 \mathrm{~mL}$ de tampão McIlvaine pH 6,0 e $1 \mathrm{~mL}$ de solvente orgânico. O controle foi realizado com 1 $\mathrm{mL}$ de extrato bruto adicionados de $0,5 \mathrm{~mL}$ de tampão Mcllvaine $\mathrm{pH}$ 6,0 e $1 \mathrm{~mL}$ de solvente orgânico.

Periodicamente, retirou-se alíquotas de $0,05 \mathrm{~mL}$ as quais foram utilizadas para a hidrólise de pNPP $12 \mathrm{mM}$, a $50^{\circ} \mathrm{C}$, por 10 minutos. Os períodos analisados foram: $0,1,2$, 3, 4, 24 e 48 horas. Os resultados foram expressos como atividade residual (em \%) obtida em relação à atividade quantificada no tempo zero para cada derivado e enzima livre. Em seguida, foram determinados os valores de $t_{50}$.

\subsection{Reação de transesterificação utilizando substrato sintético}

Um método colorimétrico para avaliar a atividade de transesterificação enzimática foi realizada um screening rápido. Para esse experimento foram utilizadas as lipases de S. thermophilum e de A. phoenicis imobilizadas nos suportes: Octyl-sepharose, Sepabeads C-18 e Duolite. O método de dosagem de acordo com Teng \& Xu (2007), com modificações, foi aplicado para tal finalidade.

A reação foi preparada utilizando $10 \mathrm{mg}$ do derivado, $1 \mathrm{~mL}$ de $p$ nitrofenilpalmitato ( $10 \mathrm{mM}$ em ciclohexano) e $6 \mu \mathrm{L}$ de etanol ou metanol. A suspensão foi incubada em thermomixer a $30^{\circ} \mathrm{C}, 35^{\circ} \mathrm{C}, 40^{\circ} \mathrm{C}, 45^{\circ} \mathrm{C}, 50{ }^{\circ} \mathrm{C}, 55^{\circ} \mathrm{C}$ e $60{ }^{\circ} \mathrm{C}$, a 500 rpm.

Após 1 hora de reação foi adicionado $1 \mathrm{~mL}$ de $\mathrm{NaOH} 0,1$ mol. L $\mathrm{L}^{-1}$ para interromper 
a reação.

A unidade (U) da atividade enzimática foi definida como a liberação de $1 \mu \mathrm{mol}$ de $p$-nitrofenol ( $\mathrm{pNP})$ por minuto, por grama de derivado $(\mathrm{U} / \mathrm{g})$.

\subsection{Reação de transesterificação enzimática}

A reação de transesterificação enzimática foi conduzida em meio não aquoso. Inicialmente foram utilizados os derivados de $S$. thermophilum e A. phoenicis em Sepabeads C-18 e Duolite. A reação foi realizada com uma razão molar de metanol:óleo de soja (1:2), para um volume final de 2,5 mL, $82 \%$ de ciclohexano e 12\% (m/v óleo) de derivado seco em acetona.

Posteriormente foi padronizada a utilização de etanol para essa reação. Os demais óleos vegetais testados para a transesterificação foram: açaí, buriti, castanha do Brasil e girassol. Em adição, a partir do estudo de Kourmentza et al. (2018), foi utilizado o material de descarte borra de café seco em estufa a $35^{\circ} \mathrm{C}$ por 24 horas. Os óleos selecionados foram obtidos de forma comercial no Mundo dos óleos@ .

Para os experimentos subsequentes foram estabelecidas novas concentrações e ajustes (KOURMENTZA et al., 2018):

(1) álcool:óleo vegetal (3:1) para um volume final de 2,061 mL + 10\% (m/v de óleo) de derivado seco, sem adição de ciclohexano.

(2) álcool:óleo vegetal (1:2) para um volume final de 2,5 mL + 10\% (m/v de óleo) de derivado seco e $82 \%$ de ciclohexano.

A secagem dos derivados foi realizada através da lavagem, utilizando filtração a vácuo, com as seguintes soluções de água:acetona: 80:20, 60:40, 40:60, 20:80 e 0:100 (VICI et al. 2015).

Todos os testes foram incubados a $50{ }^{\circ} \mathrm{C}$, com agitação orbital de $120 \mathrm{rpm}$ por 24 horas. Ao final das reações, foi feita a recuperação do derivado através da filtração sob vácuo. A formação de biodiesel foi avaliada por Cromatografia Gasosa (CG), para qualificação e quantificação.

\subsection{Análise por Cromatografia Gasosa (CG)}


Para as análises por CG, foi adotado o método de análise em parceira com o Prof. Dr. Anizio Marcio de Faria, no laboratório de Pesquisas em Materiais de Separação e Cromatografia Química no Instituto de Ciências Exatas e Naturais do Pontal, Universidade Federal de Uberlândia, Ituiutaba, MG - Brasil.

Para a preparação das amostras para análise no Cromatógrafo a gás, $10 \mu \mathrm{L}$ de cada amostra foram adicionados a $1000 \mu \mathrm{L}$ de solução de heptadecanoato de metila (padrão interno) a $500 \mathrm{mg} \mathrm{L}^{-1}$ antes da introdução no sistema cromatográfico. As análises foram realizadas em um cromatógrafo a gás da marca Thermo ${ }^{\circledR}$, modelo Focus GC. Temperatura do forno da coluna: isoterma a $190{ }^{\circ} \mathrm{C}$; injeção Split, com divisão de fluxo 1:10 e temperatura de $250{ }^{\circ} \mathrm{C}$; detecção por ionização em chama, com temperatura do detector a $250^{\circ} \mathrm{C}$; injeção de $1 \mu \mathrm{L}$ de amostra; tempo total de análise de cada amostra de 7 minutos. Coluna empregada: coluna capilar com fase estacionária de poli(etilenoglicol), marca Carbowax, $30 \mathrm{~m}$ de comprimento, 0,32 $\mathrm{mm}$ de diâmetro interno e $0,25 \mu \mathrm{m}$ de espessura de filme. A quantificação das amostras em total de ésteres segue a norma EN (European Standard Norme) 14103:2003.

\subsection{Análises físico-químicas do biodiesel produzido por catálise enzimática}

As amostras de biodiesel produzidas através da reação de transesterificação enzimática foram secadas em placa de aquecimento a $50^{\circ} \mathrm{C}$ por 1 minuto e armazenadas em recipiente adequado com vedação até seguir para as análises físico-químicas.

\subsection{1. Índice de acidez}

De acordo com os mesmos princípios do método da AOCS Cd 3d-63, foi utilizado o método titulométrico alternativo desenvolvido por Aricetti (2010) para determinar a acidez do biodiesel produzido. Os reagentes utilizados foram: Álcool etílico P.A. (Synth); Água destilada; Solução padronizada aquosa de $\mathrm{NaOH} 0,02$ mol. L ${ }^{-1}$; Solução alcoólica de fenolftaleína $1 \%(\mathrm{~m} / \mathrm{v})$.

O solvente de titulação foi preparado com $500 \mathrm{~mL}$ de água destilada e $500 \mathrm{~mL}$ de álcool etílico. A 2 g de amostra, colocadas em um frasco de titulação, adicionou-se 25 $\mathrm{mL}$ de etanol 50\% e 1 gota de fenolftaleína. Procedeu-se então a titulação com a solução padronizada aquosa de $\mathrm{NaOH} 0,02 \mathrm{~mol}$. $\mathrm{L}^{-1}$ até apresentar a coloração rosa. Este mesmo 
procedimento foi realizado para o branco a fim de descontar a sua acidez daquelas obtidas para as amostras de biodiesel.

O cálculo de índice de acidez foi realizado de acordo com a equação (1).

$$
\text { Índice de acidez }=\frac{(A-B) x C \times 56,1}{M} \quad \text { Equação } 1
$$

Onde, A é o volume, em mL, de solução titulante usados para titular uma amostra, B é o volume de titulante para a titulação do branco, em $\mathrm{mL}, \mathrm{C}$ é a concentração da solução titulante, em mol por litro e M é a massa da amostra, em gramas.

\subsection{2. Índice de iodo}

O método de Friedmann (1924) foi desenvolvido para a determinação do índice de iodo de óleos e gorduras. O método utilizado nesse trabalho foi aquele modificado por Aricetti (2010). Os reagentes utilizados foram: Álcool etílico P.A. (Synth); Solução de iodo 0,1 mol L-1 em meio etanólico; Solução padronizada de tiossulfato de sódio 0,1 mol. $\mathrm{L}^{-1}$; Solução de amido $1 \%(\mathrm{~m} / \mathrm{v})$; Água destilada gelada (temperatura entre 5 e $10^{\circ} \mathrm{C}$ ).

A amostra $(0,10 \mathrm{~g})$ foi dissolvida em $15 \mathrm{~mL}$ de álcool etílico - em um Erlenmeyer de $500 \mathrm{~mL}$ - e agitada fortemente com agitador magnético durante 2 minutos. Após a solubilização da amostra, adicionou-se $20 \mathrm{~mL}$ de solução etanólica de iodo $0,1 \mathrm{~mol}$. L-1. Agitou-se, com agitador magnético, durante 5 minutos com agitação moderada. Em seguida, adicionou-se $200 \mathrm{~mL}$ de água destilada e gelada e tampou-se o frasco de titulação com uma rolha de borracha. A solução teve a agitação reduzida para lenta, onde permaneceu durante mais 5 minutos. Posteriormente, a solução foi titulada com solução padronizada de tiossulfato de sódio $0,1 \mathrm{~mol} \mathrm{~L}^{-1}$ até adquirir cor levemente amarela, quando foram adicionados $3 \mathrm{~mL}$ de solução de amido, momento em que a cor se tornou azul. Deu-se continuidade a titulação até o desaparecimento da cor azul. O ponto final da titulação da solução contendo amostra é uma coloração branca com aparência leitosa. Todas as titulações de amostra foram acompanhadas por uma prova de branco.

O cálculo de índice de iodo foi realizado de acordo com a equação (2). 


$$
\text { Índice de iodo }=\frac{(B-A) x C \times 12,69}{M} \quad \text { Equação } 2
$$

Onde, A é o volume, em mL, de $\mathrm{Na}_{2} \mathrm{~S}_{2} \mathrm{O}_{3}$ gasto na titulação da amostra, B é o volume, em mL, de $\mathrm{Na}_{2} \mathrm{~S}_{2} \mathrm{O}_{3}$ gasto na titulação do branco, $\mathrm{C}$ é a concentração, em mol $\mathrm{L}^{-1}$, da solução de $\mathrm{Na}_{2} \mathrm{~S}_{2} \mathrm{O}_{3}$ e $\mathrm{M}$ é a massa, em gramas, da amostra.

\subsubsection{Cálculo do rendimento da transesterificação enzimática}

O cálculo de rendimento foi realizado de acordo com Oliveira et al. (2012) e está representado na equação 3.

$$
\text { Rendimento }(\%)=\frac{\text { Massa de biodiesel }}{\text { Massa de óleo }} \times 100 \quad \text { Equação } 3
$$

A massa de biodiesel foi pesada depois da reação de transesterificação enzimática em função da massa de óleo de girassol empregada na transesterificação.

Para fins de cálculo, de acordo com Zambelli (2009) a densidade do óleo de girassol é $0,891 \mathrm{~g} / \mathrm{cm}^{3}$, a $25^{\circ} \mathrm{C}$.

\subsection{Hidrólise dos óleos vegetais nativos}

De acordo com as metodologias de PEREIRA et al. (2015); VICI (2015) e FACCHINI et al. (2014), os óleos de soja (Glycine max (L.) Merr), buriti (Mauritia flexuosa), açaí (Euterpe oleracea), pracaxi (Pentaclethra Macroloba), ojon (Elaeis oleifera (Kunth)) e tucumã (Astrocaryum aculeatum) foram submetidos a hidrólise em um sistema bifásico orgânico-aquoso, utilizando a lipase de $A$. phoenicis imobilizada em suporte Octyl-sepharose, que demonstrou maior eficiência de atividade hidrolítica e estabilidade físico-química. Os óleos selecionados foram obtidos de forma comercial no Mundo dos óleos ${ }^{\circledR}$.

A reação consistiu em $5 \mathrm{~mL}$ de tampão Tris- $\mathrm{HCl}$ 0,1M pH 6,0, 4,5 mL de ciclohexano, $0,5 \mathrm{~mL}$ do óleo vegetal e $4 \%$ de derivado $(\mathrm{m} / \mathrm{v})$.

A reação foi incubada a $50{ }^{\circ} \mathrm{C}, 120 \mathrm{rpm}$ por 24 horas. Alíquotas de $0,1 \mathrm{~mL}$ foram 
retiradas periodicamente e preparadas para análises qualitativas e quantitativas, através do método colorimétrico sulfofosfo-vanilina (ANSCHAU et al., 2017; PÉREZ et al., 2018). O reagente fosfovanilina, foi preparado utilizando $6 \mathrm{mg}$ de vanilina (SigmaAldrich) dissolvida em $100 \mathrm{~mL}$ de água quente e por fim diluído em 85\% de ácido fosfórico. Ácido oleico (1 mg/mL em ácido sulfúrico) foi utilizado para obtenção da curva padrão. A reação foi conduzida de acordo Figura 7. O resultado obtido foi expresso em $\mathrm{mg} / \mathrm{mL}$ de ácidos graxo totais obtidos através da reação de hidrólise.

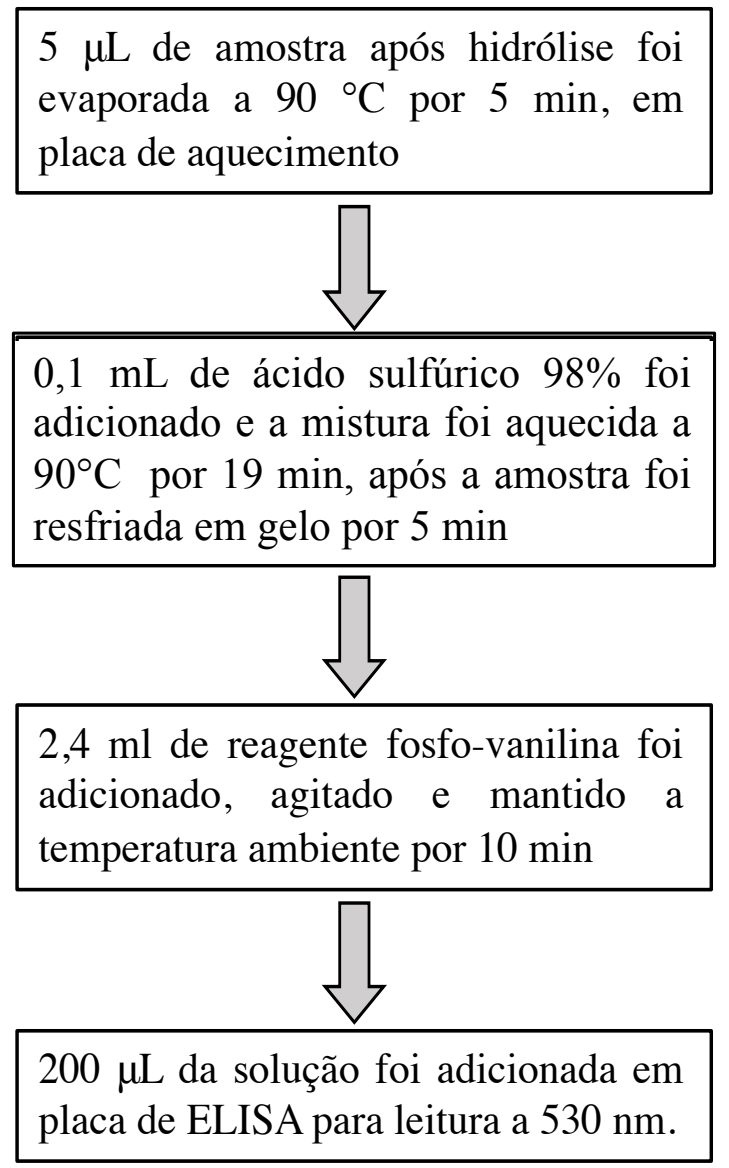

Figura 7. Sequência de preparação da metodologia de quantificação de ácidos graxos totais em mg/mL. De acordo com a metodologia de Anschau et al. (2017); Pérez et al. (2018).

\subsection{Análise dos experimentos}

Todos os experimentos e ensaios foram realizados, no mínimo, em triplicatas. Os experimentos foram analisados com base na média e no desvio padrão. Para a análise dos experimentos e representação gráfica foram utilizados os softwares Microsoft Office Excel 2017, Origin Pro e STATISTICA 12.0. 
IV-RESULTADOS E DISCUSSÕES 
Este trabalho está dividido em cinco partes, em cada uma delas encontram-se os resultados obtidos e suas respectivas discussões. 
PARTE I - Screening e seleção de fungos filamentosos 


\subsubsection{Screening dos fungos produtores de lipase em meio de cultivo sólido}

O screening em placas de ágar é bastante utilizado e observado em diversas publicações, principalmente utilizando a triburitina como substrato devido a fácil identificação de zonas claras ao redor das colônias, indicando a presença e atividade da lipase (SAMAD et al., 1989; CARDENAS et al., 2001). Em adição, o uso de corantes como: Rodamina B e Victoria Blue tem sido bastante utilizado para o screening de inúmeros microrganismos (KO et al., 2005; HASAN et al., 2009; AKBARI et al., 2011).

Com o objetivo de pré-selecionar os microrganismos com capacidade lipolítica, realizou-se cultivo em meio SR sólido com tributirina. 11 fungos foram escolhidos para esse screening. Desses, 3 são classificados como termófilos - Humicola grisea; Humicola insolens e Scytalidium thermophilum - e 8 como mesófilos - Trichoderma harzianum; Penicillium phinophilum; Aspergillus japonicus; Aspergillus caespitosus; Aspergilllus phoenicis; Aspergillus brasiliensis; Aspergillus clavatus e Aspergillus niveus.

Ao final do período de 72 horas de crescimento, os fungos selecionados foram aqueles onde foi possível observar a formação de um halo de hidrólise, a partir da análise das placas e da entre o diâmetro do halo formado e o diâmetro da cultura fúngica. Foram selecionados um total de 7 fungos, sendo eles: A. phoenicis, A. caespitosus, A. clavatus, S. thermophilum, A. japonicus, H. grisea e A. niveus (Figura 8). Os demais fungos: Humicola insolens, Trichoderma harzianum, Penicillium phinophilum e Aspergillus brasiliensis, não apresentaram área de hidrolise satisfatória para prosseguimento nos estudos, portanto, foram descartados.

Os 7 fungos selecionados nesse experimento foram submetidos a fermentação submersa, a fim de identificar os fungos que melhor produzem lipases extracelulares. 
A
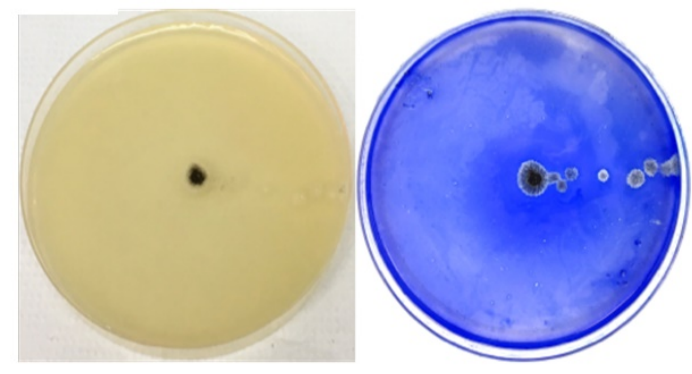

$\mathbf{B}$
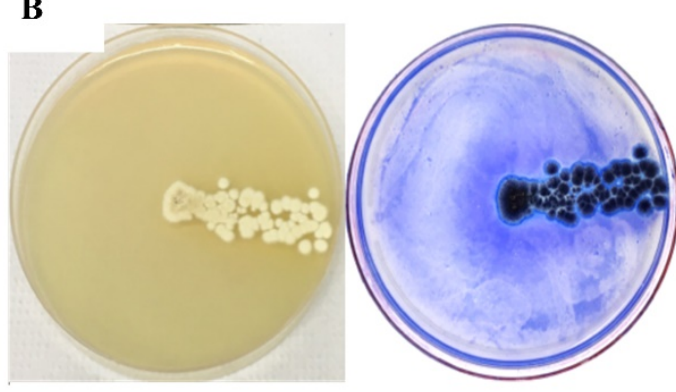

C
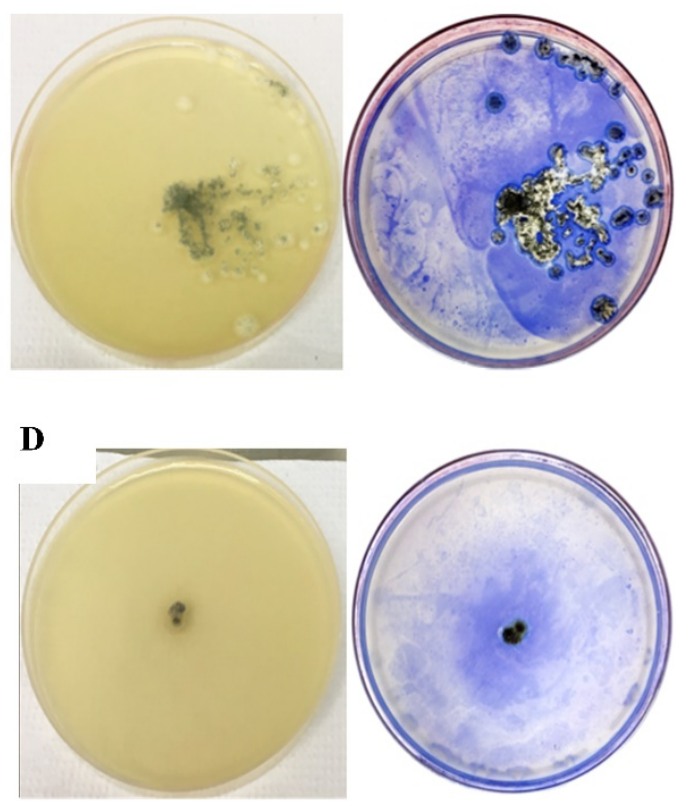

$\mathbf{E}$
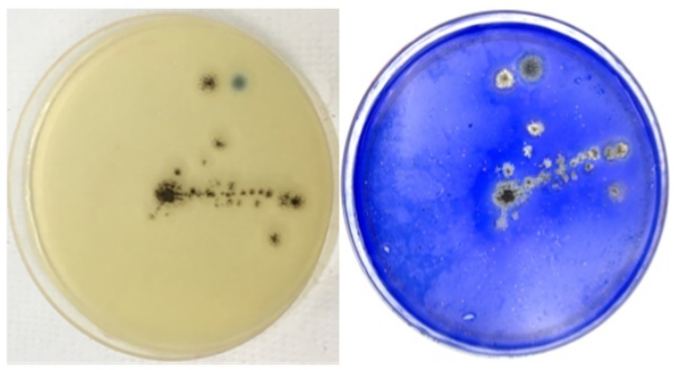

F
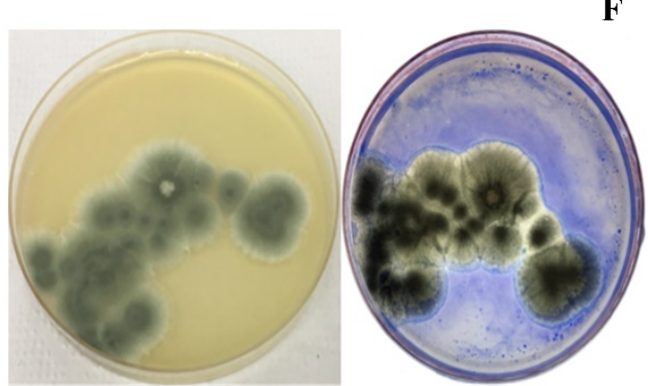

G
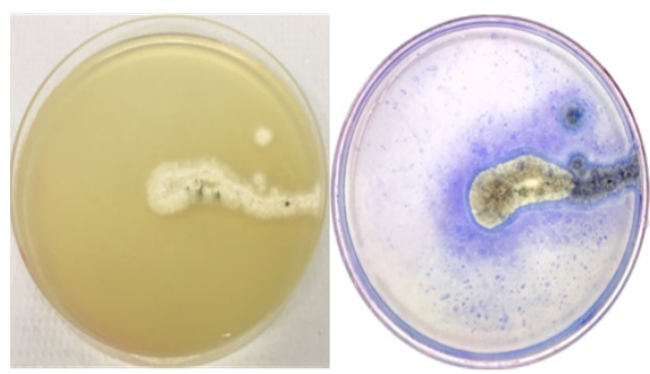

Figura 8. Screening dos fungos filamentos, cultivados em tributirina $1 \%$ como fonte de carbono. As imagens demostram os fungos que apresentaram formação de halo de hidrólise, indicando a capacidade de produzir lipase. Para cada fungo, é possível visualizar duas imagens com as placas antes e depois da coloração com Victoria Blue $(0,01 \% \mathrm{~m} / \mathrm{v})$, sendo possível identificar a formação de uma zona clara na primeira imagem, e a área de hidrolise com uma coloração azul escuro na segunda. (A) A phoenicis, halo $1,9 \mathrm{~cm}$ - colônia $0,3 \mathrm{~cm}$ - razão 6,33 ; (B) A. caespitosus, halo $1,7 \mathrm{~cm}$ - colônia $0,6 \mathrm{~cm}$ - razão 2,83; (C) A. clavatus, halo 1,6 cm colônia $0,4 \mathrm{~cm}$ - razão 4 ; (D) $S$. thermophilum, halo $1,5 \mathrm{~cm}$ - colônia $0,5 \mathrm{~cm}$ - razão 3 ; (E) $A$. japonicus, halo 1,4 cm - colônia 0,4 cm - razão 3,5; (F) $H$. grisea, halo $1,0 \mathrm{~cm}$ - colônia $1,5 \mathrm{~cm}$ - razão 0,$67 ;$ (G) A. niveus, halo $0,5 \mathrm{~cm}$ - colônia $0,6 \mathrm{~cm}$ - razão 0,83 . 


\subsubsection{Fermentação submersa e deteç̧ão de atividade enzimática de lipase extracelular}

A realização de um screening é de extrema importância para a seleção do microrganismo foco desse estudo. Para tanto, foi realizada uma seleção em fermentação submersa na qual foram utilizadas as cepas pré-selecionadas anteriormente.

O cultivo em fermentação submersa foi inicialmente feito com meio SR (RIZZATTI et al., 2001) suplementado com óleo de soja comercial 1\%. Os meios de cultivo permaneceram 96 horas em agitação a $100 \mathrm{rpm}$ e a $30{ }^{\circ} \mathrm{C}$ para os fungos mesófilos e $40{ }^{\circ} \mathrm{C}$ para os termófilos. Após filtração a vácuo, o extrato bruto foi submetido a ensaios enzimáticos para determinar a atividade lipolítica extracelular em diferentes temperaturas. Os valores foram expressos em $\mathrm{U} / \mathrm{mL}$ e estão apresentados na Tabela 3. O ensaio enzimático foi conduzido em diferentes valores de temperatura, visando identificar a temperatura ótima para atividade da lipase produzida.

Tabela 3. Dosagem enzimática dos extratos brutos obtidos em diferentes temperaturas. Valores de atividade hidrolítica $\mathrm{em} \mathrm{U} / \mathrm{mL}$ das lipases extracelulares obtidas nos extratos brutos dos fungos selecionados.

\begin{tabular}{cccccccc}
\hline \multirow{7}{*}{$\begin{array}{c}\text { Temperatura } \\
\text { de ensaio } \\
\left({ }^{\circ} \mathrm{C}\right)\end{array}$} & \begin{tabular}{c}
$S$. \\
\cline { 2 - 8 }
\end{tabular} & $\begin{array}{c}\text { Atividade (U/mL) } \\
\text { thermophilum }\end{array}$ & $\begin{array}{c}\text { A. } \\
\text { grisea }\end{array}$ & $\begin{array}{c}\text { A. } \\
\text { niveus }\end{array}$ & $\begin{array}{c}\text { clavatus } \\
\text { caespitosus }\end{array}$ & $\begin{array}{c}A . \\
\text { phoenicis }\end{array}$ & $\begin{array}{c}\text { A. } \\
\text { japonicus }\end{array}$ \\
\hline $\mathbf{3 0}$ & 0,35 & 0,20 & 0,09 & 0,09 & 0,09 & 0,92 & 0,01 \\
$\mathbf{4 0}$ & 0,95 & 0,10 & 0,09 & 0,13 & 0,04 & 1,35 & 0,01 \\
$\mathbf{4 5}$ & 1,10 & 0,13 & 0,09 & 0,12 & 0,10 & 4,10 & 0,37 \\
$\mathbf{5 0}$ & 1,32 & 1,98 & 0,08 & 0,02 & 0,8 & 6,04 & 0,17 \\
$\mathbf{5 5}$ & 0,49 & 1,23 & 0,08 & 0,01 & 0,21 & 4,80 & 0,06 \\
$\mathbf{6 0}$ & 0,19 & 0,31 & 0,01 & 0,01 & 0,01 & 1,89 & 0,02 \\
\hline
\end{tabular}

A partir dos dados da Tabela 3, é possível identificar que os fungos $S$. thermophilum $(1,32 \mathrm{U} / \mathrm{mL}), H$. grisea $(1,96 \mathrm{U} / \mathrm{mL})$ e A. phoenicis $(6,4 \mathrm{U} / \mathrm{mL})$ apresentaram melhor produção de lipase nas condições de cultivo utilizadas. Além disso, 
a temperatura ótima para ensaio enzimático das lipases dos três fungos é de $50^{\circ} \mathrm{C}$.

As proteínas foram quantificadas como descrito em Materiais e Métodos e, desse modo, foi possível obter as atividades específicas das lipases fúngicas (Figura 9). $S$. thermophilum apresentou a maior produção proteica seguido por H. grisea, com concentração de proteínas de 31 e $20,8 \mathrm{mg} / \mathrm{mL}$, respectivamente. A. phoenicis apresentou a melhor atividade específica $(49,61 \mathrm{U} / \mathrm{mg})$ em comparação aos demais fungos.

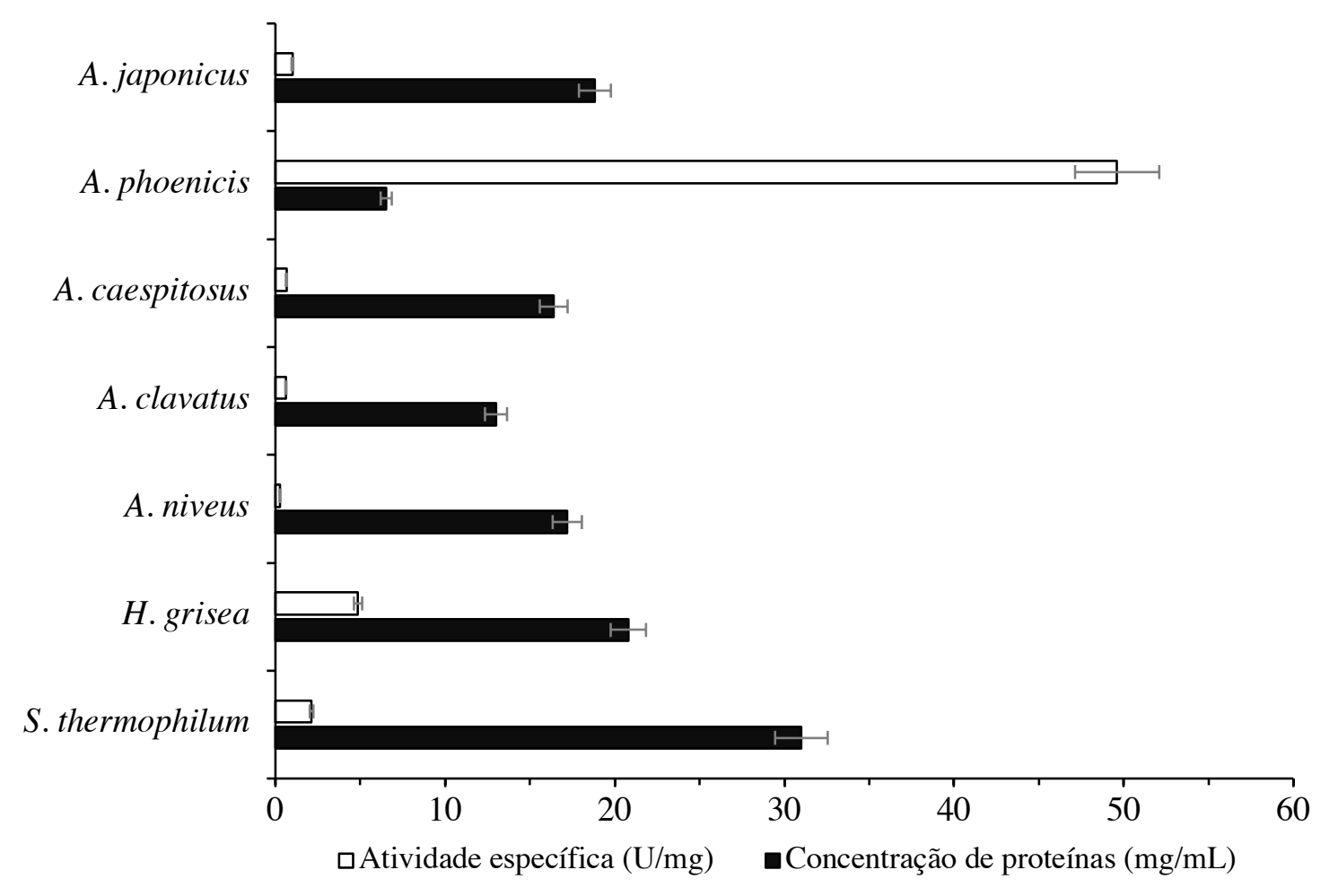

Figura 9. Avaliação da concentração de proteínas e atividade específica dos extratos brutos extracelulares. Valores de atividade específica em U/mg e concentração de proteínas em $\mathrm{mg} / \mathrm{mL}$, do extrato bruto filtrado, obtido dos fungos produtores de lipases selecionados para etapa de fermentação submersa. Os fungos foram inoculados em meio SR, suplementado com óleo de soja $1 \%$ e incubados por $96 \mathrm{~h}, 100 \mathrm{rpm}$, a $30^{\circ} \mathrm{ou} 40^{\circ} \mathrm{C}$.

A seleção de microrganismos produtores de enzimas de interesse biotecnológico mostra-se como uma etapa importante no processo de pesquisa onde será empregada. De acordo com Michelin (2009) cada espécie de microrganismo é capaz de produzir um pool enzimático característico. Portanto, existem variações de uma espécie para a outra em relação a quantidade absoluta ou relativa de enzimas que são produzidas. 


\subsubsection{Teste de viabilidade dos micélios para obtenção de lipase intracelular}

Após obtenção da cultura fúngica em fermentação submersa, os micélios obtidos através da filtração à vácuo foram preparados para os testes de dosagem enzimática e dosagem de proteínas. As temperaturas de $45{ }^{\circ} \mathrm{C}$ e $50{ }^{\circ} \mathrm{C}$ utilizadas para o teste de dosagem enzimática foram selecionadas a partir dos resultados obtidos no experimento anterior.

Os resultados obtidos demonstram a baixa atividade hidrolítica intracelular dos fungos em estudo (Tabela 4), em relação aos resultados obtidos para o extrato bruto extracelular a $50{ }^{\circ} \mathrm{C}$. O extrato bruto intracelular de S. thermophilum, H. grisea e $A$. phoenicis apresentaram 4,4, 8,25 e 13,72 vezes menos atividade hidrolítica, respectivamente. Desta maneira, é possível identificar a maior secreção de lipase para o meio extracelular quando comparada a quantidade de lipase que permanece intracelular.

Tabela 4. Valores de atividade hidrolítica $(\mathrm{U} / \mathrm{mL})$ das lipases intracelulares obtidas a partir dos micélios macerados dos fungos selecionados.

\begin{tabular}{cccccccc}
\hline \multirow{7}{*}{$\begin{array}{c}\text { Temperatura } \\
\text { de ensaio } \\
\left({ }^{\circ} \mathrm{C}\right)\end{array}$} & $\begin{array}{c}S . \\
\text { thermophilum }\end{array}$ & $\begin{array}{c}H . \\
\text { grisea }\end{array}$ & $\begin{array}{c}\text { A. } \\
\text { niveus }\end{array}$ & $\begin{array}{c}\text { A. } \\
\text { clavatus }\end{array}$ & $\begin{array}{c}\text { A. } \\
\text { caespitosus }\end{array}$ & $\begin{array}{c}\text { A. } \\
\text { phoenicis }\end{array}$ & $\begin{array}{c}\text { A. japonicus } \\
\text { jolmL) }\end{array}$ \\
\hline $\mathbf{4 5}$ & 0,36 & 0,34 & 0,08 & 0,25 & 0,14 & 0,35 & 0,39 \\
$\mathbf{5 0}$ & 0,30 & 0,24 & 0,07 & 0,14 & 0,08 & 0,44 & 0,38 \\
\hline
\end{tabular}

Em relação a dosagem de proteínas do extrato bruto intracelular foi possível observar menor produção proteica quando comparado ao extrato extracelular. Os fungos A. phoenicis, S. thermophilum e $H$. grisea apresentaram atividade específica de 4,8 U/mg, 4,14 U/mg e 3,92 mg/mL, respectivamente (Figura 10). No trabalho de Facchini (2014) foi relatada uma boa taxa de atividade hidrolítica pelas lipases produzidas pelo fungo $A$. phoenicis e a característica de baixa concentração de proteínas.

Os demais fungos A. japonicus, A. caespitosus, A. clavatus e A. niveus não apresentaram produção proteica satisfatórias. Em comparação com o extrato bruto, a massa micelial não possui vantagens para obtenção das enzimas alvo para este estudo. 
Desta maneira, prosseguiu-se o trabalho com as enzimas produzidas por $S$. thermophilum, H. grisea e A. phoenicis secretadas extracelularmente, através de fermentação submersa. De acordo com Agger et al. (2002); Peixoto (2004), a capacidade do fungo secretar grandes quantidades de enzimas para o meio de cultivo tem estimulado pesquisas para o desenvolvimento de fermentação em larga escala, purificação enzimática e técnicas de biologia molecular.

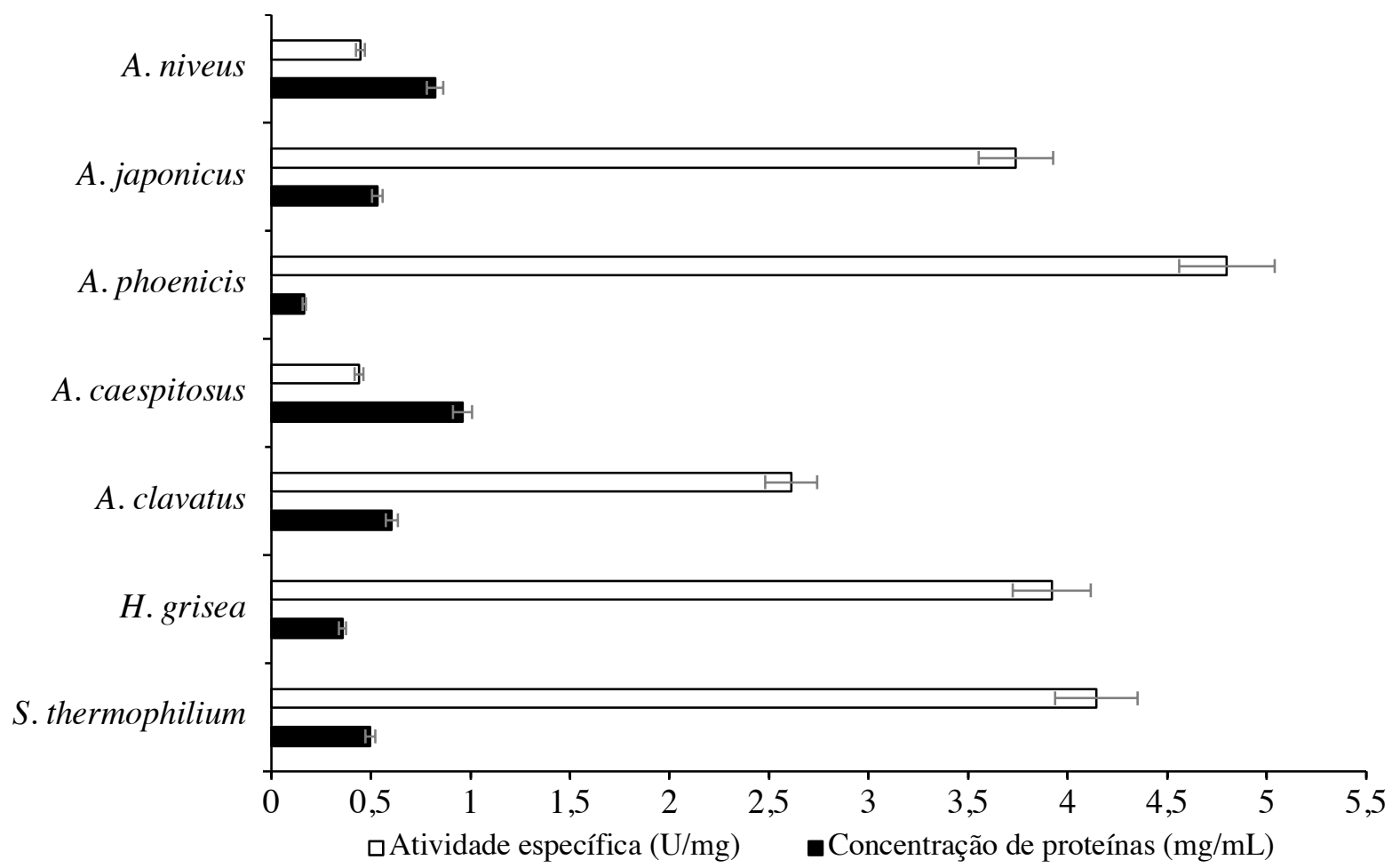

Figura 10. Avaliação da concentração de proteínas e atividade específica intracelulares. Valores de atividade específica em U/mg e concentração de proteínas em $\mathrm{mg} / \mathrm{mL}$, das lipases intracelulares obtidas através do processo de maceração dos micélios. Os fungos foram inoculados em meio SR, suplementado com óleo de soja $1 \%$ e incubados por $96 \mathrm{~h}, 100 \mathrm{rpm}$, a $30^{\circ}$ ou $40^{\circ} \mathrm{C}$. 


\section{PARTE II - Melhoramento \\ da produção de lipases por \\ S. thermophilum, $A$. \\ phoenicis e H. grisea}




\subsubsection{Padronização do meio de cultura e tempo de crescimento para fermentação submersa}

Os meios de cultura, SR e Khanna, foram suplementados com óleo de soja $1 \%$ e mantidos, após inóculo, por 168 horas, $100 \mathrm{rpm}$ e a $30{ }^{\circ} \mathrm{C}$ para $A$. phoenicis e $40{ }^{\circ} \mathrm{C}$ para S. thermophilum e H. grisea. De acordo com estudos de Facchini (2014) o fungo $A$. phoenicis é capaz de se desenvolver em diferentes temperaturas, porém a $30{ }^{\circ} \mathrm{C}$ o crescimento apresentou os melhores resultados de produção de lipase.

A Figura 11 representa os resultados de atividade lipolítica obtidas das alíquotas retiradas nos períodos de 72, 96, 120, 144 e 168 horas. Entre 0 e 48 horas não houve detecção de atividade lipolítica significativa (dados não mostrados). Observa-se que os fungos S. thermophilum (Figura 11 - A), A. phoenicis (Figura 11 - B) e H. grisea (Figura 11 - C) se desenvolveram melhor e tiveram melhor atividade lipolítica no meio de cultivo SR. A produção de lipases para S. thermophilum, A. phoenicis e H. grisea foi melhor com 120, 144 e 168 horas, respectivamente. O tempo de cultivo é uma variável que possui elevada influência na produção de enzimas, pois períodos longos podem levar ao esgotamento de nutrientes e substratos, levando a um declínio da produção enzimática (PELCZAR et al., 1996). 

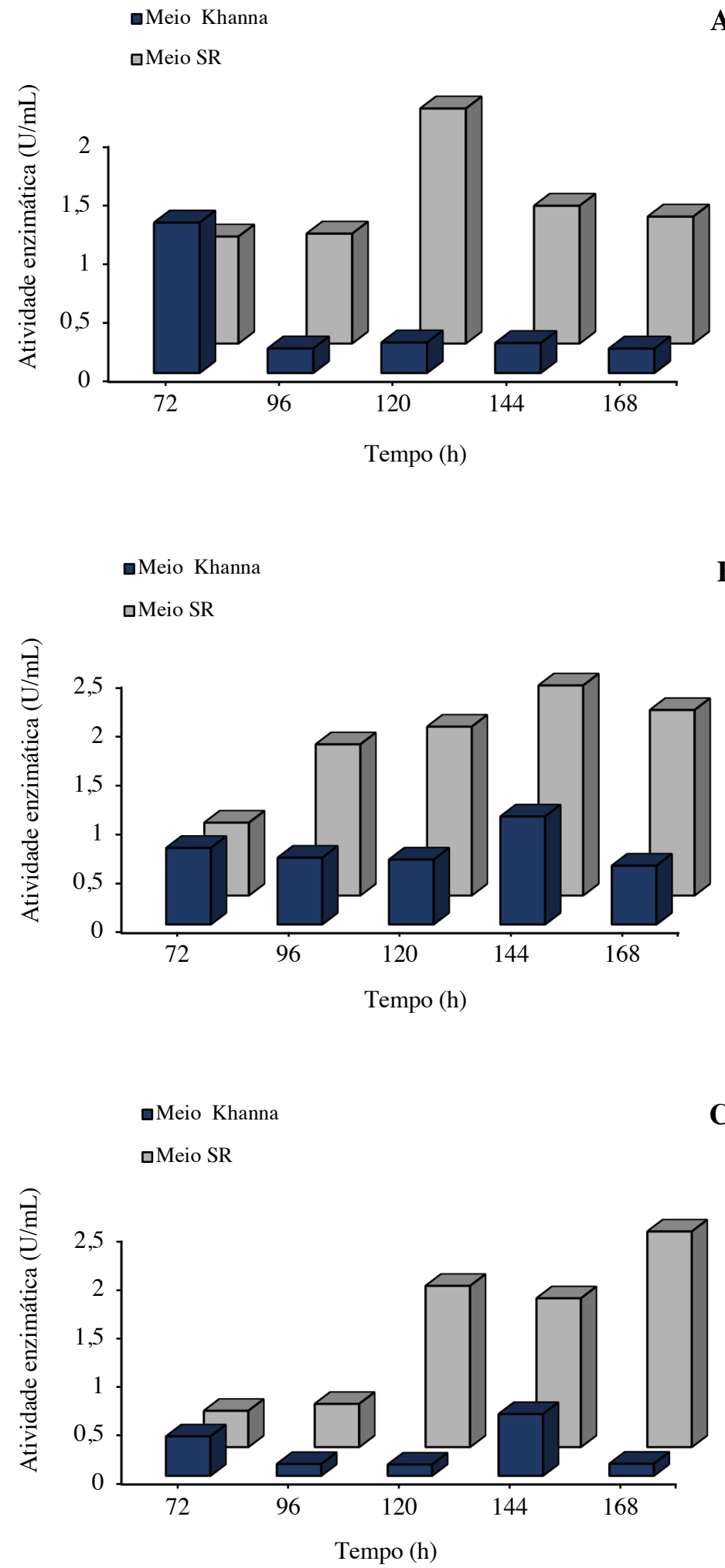

Figura 11. Efeito dos meios de cultivos SR e Khanna na produção de lipases por (A) $S$. thermophilum (B) A. phoenicis e (C) H. grisea. Os meios foram suplementados com óleo de soja comercial 1\%. Amostras foram retiradas diariamente por até 7 dias. 
A Tabela 5 apresenta os valores de atividade $(\mathrm{U} / \mathrm{mL})$, proteína $(\mathrm{mg} / \mathrm{mL})$ e atividade específica (U/mg) obtidos para cada fungo em seu melhor tempo de cultivo.

Tabela 5. Atividade lipolítica e produção de proteínas obtidas nos melhores tempos de cultivo fúngico para o crescimento em meio SR, suplementado com $1 \%$ de óleo de soja.

\begin{tabular}{ccccc}
\hline Fungo & $\begin{array}{c}\text { Tempo de } \\
\text { cultivo }\end{array}$ & $\begin{array}{c}\text { Atividade } \\
\text { enzimática } \\
(\mathrm{U} / \mathrm{mL})\end{array}$ & Proteína $(\mathrm{mg} / \mathrm{mL})$ & $\begin{array}{c}\text { Atividade } \\
\text { específica } \\
\text { (U/mg) }\end{array}$ \\
\hline S. thermophilum & $120 \mathrm{~h}$ & 2,0 & 3,82 & 0,52 \\
A. phoenicis & $144 \mathrm{~h}$ & 2,14 & 1,27 & 1,68 \\
H. grisea & $168 \mathrm{~h}$ & 2,2 & 7,42 & 0,29 \\
\hline
\end{tabular}

Adicionalmente, é possível inferir que a presença das fontes de nitrogênio peptona $0,02 \%$ e extrato de levedura $0,45 \%$ no meio SR, auxiliaram na melhor maneira no crescimento dos fungos selecionados e consequentemente na produção de lipase, quando comparada ao meio Khanna que contém apenas a fonte de nitrogênio extrato de levedura 0,1\%. Na literatura encontramos um estudo semelhante com a levedura Yarrowia lipolytica (FICKERS et al., 2004). Nesse trabalho a melhor fonte de nitrogênio para a produção de lipases foi triptona seguida de peptona.

Na literatura é possível encontrar autores que determinaram o tempo de cultivo para os fungos utilizados em suas pesquisas. No estudo de Shu et al. (2007) o tempo de 80 horas de cultivo para $A$. niger foi determinado como o melhor período para produção de lipase. Hiol et al. (2000) registraram que com 96 horas a produção e secreção de lipases de Rhizopus oryzae é eficiente. Cada microrganismo possui seu melhor tempo de crescimento e secreção de lipases, o que pode ainda ser influenciado pelas condições de cultivo e composição do meio de cultura.

Analisando estes resultados atribuiu-se o meio de cultura SR, como meio de cultivo padrão para a realização dos próximos experimentos.

\subsubsection{Influência das fontes de carbono para a produção de lipase extracelular}

A fonte de carbono exerce grande influência na produção enzimática, sendo capaz de induzir ou inibir a secreção de lipase. A fonte de lipídios influencia tanto no 
crescimento do microrganismo como na indução da produção de lipases. Óleos de origens diferentes apresentam composições e concentrações distintas de ácidos graxos. Objetivando testar a influência de diferentes óleos como fonte de carbono e indutor da produção de lipases pelos fungos selecionados, realizou-se um experimento utilizando seis óleos de origens diferentes nos meios de cultura.

Foram utilizados óleos de soja (Glycine max (L.) Merr.), girassol (Helianthus annuus L.), buriti (Mauritia flexuosa), açaí (Euterpe oleracea), peixe e pequi (Caryocar brasiliense). O meio de cultura SR foi preparado e complementado com 1\% de cada um dos seis óleos a serem testados.

Comparando com os resultados obtidos quando incubado em meio suplementado com óleo de soja (controle) observa-se que o fungo $S$. thermophilum teve uma produção 3,5 vezes maior de lipase com 72 horas de crescimento quando suplementado com óleo de buriti 1\% (Figura 12.A), sendo esse o tempo que apresenta o pico de produção enzimática para este fungo, com atividade enzimática de 2,14 U/mL, com concentração de proteínas de $0,166 \mathrm{mg} / \mathrm{mL}$ e atividade específica de $12,89 \mathrm{U} / \mathrm{mg}$.

Para o fungo A. phoenicis, (Figura 12.B) a produção de lipases aumentou 3,6 vezes com 72 horas de crescimento quando o meio foi suplementado com $1 \%$ de óleo de girassol. Além disso, o óleo de buriti, com pico de atividade enzimática de 1,91 U/mL a 48 horas e concentração de proteínas de $0,241 \mathrm{mg} / \mathrm{mL}$; e o óleo de açaí com pico de atividade enzimática de 1,61 U/mL a 96 horas e concentração de proteínas de 1,28 mg/mL, também proporcionaram melhora na produção de lipase por este fungo. Entretanto o óleo de girassol se apresenta como melhor resultado por ter proporcionado pico de atividade enzimática de $2,7 \mathrm{U} / \mathrm{mL}$, concentração de proteínas de $2,36 \mathrm{mg} / \mathrm{mL}$ e atividade específica de $1,14 \mathrm{U} / \mathrm{mg}$.

Por fim, para o fungo $H$. grisea (Figura 12.C) apenas o óleo de soja proporcionou uma boa taxa de produção de lipase, observando-se pico de atividade enzimática de 0,48 $\mathrm{U} / \mathrm{mL}$, concentração de proteínas de $0,59 \mathrm{mg} / \mathrm{mL}$ e atividade específica de $0,813 \mathrm{U} / \mathrm{mg}$ em 24 horas. Contudo, em todos os óleos testados H. grisea obteve baixa produção de lipase, quando comparado com os valores obtidos de $\mathrm{U} / \mathrm{mL}$ dos fungos $S$. thermophilum e A. phoenicis. Dessa forma, esse trabalho prosseguiu com o estudo desses dois últimos.

Em conclusão, as fontes de carbono estudadas não só proporcionaram uma melhora na produção enzimática, como também auxiliaram na redução do tempo de 
cultivo. Sendo assim, para os próximos experimentos, as condições de cultura foram padronizadas como cultivo por $72 \mathrm{~h}$ em SR suplementados com óleo de buriti $1 \%$ para $S$. thermophilum e com óleo de girassol 1\% para A. phoenicis (Figura 13).

Ao analisar a literatura, vários autores reportam a produção de lipases por fungos em cultivo submerso suplementado com diferentes óleos. Lima et al. (2003) estudaram o uso de óleo de oliva, soja, milho e girassol e obtiveram maior produção de lipases pelo fungo Penicillium aurantiogriseum com óleo de oliva. Colin et al. (2010) também obtiveram maior produção de lipases por Aspergillus niger utilizando óleo de oliva em comparação aos óleos de uva, soja, milho e girassol. No estudo de Acikel et al., (2011) o óleo de girassol foi selecionado como melhor indutor na produção de lipase por Rhizopus delemar.

Por fim, no estudo de Das et al. (2016), com a finalidade de encontrar as melhores condições nutricionais e demais condições para a cultura de Aspergillus tamarii crescer e produzir lipase, foi observado a eficiência do óleo de coco para a fermentação submersa. No estudo de Lakshmi et al. (1999), a indução de produção de lipase pelo microrganismo Candida rugosa e a quantidade de ácido graxo insaturado no óleo utilizado para crescimento fúngico foi correlacionado à produção de lipase. Foi observado que ao fornecer ao fungo óleos vegetais com alta porcentagem de ácidos graxos C:18n em sua composição, maior era a produção de lipase, para este microrganismo. Neste estudo, os autores determinaram o óleo de gergelim como melhor substrato para a produção de lipase. 

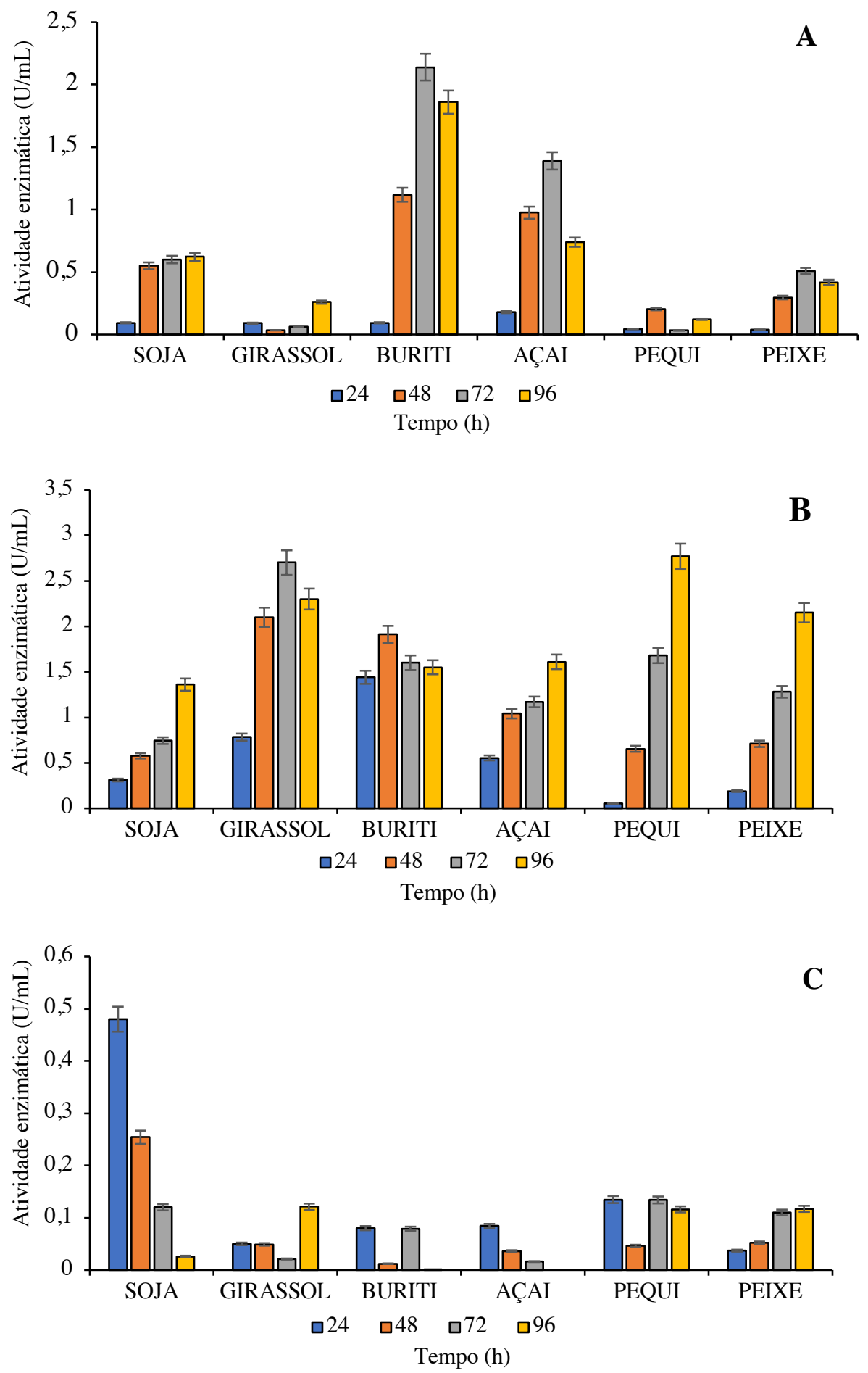

Figura 12. Influência de diferentes fontes de carbono para a produção de lipases. Valores da atividade enzimática em $\mathrm{U} / \mathrm{mL}$ obtidos dos fungos selecionados (A) $S$. thermophilum (B) A. phoenicis (C) H. grisea. O meio SR foi suplementado com $1 \%$ dos óleos selecionados em meio SR. Alíquotas foram retiradas nos períodos de 24, 48, 72 e 96 horas para dosagem enzimática. 


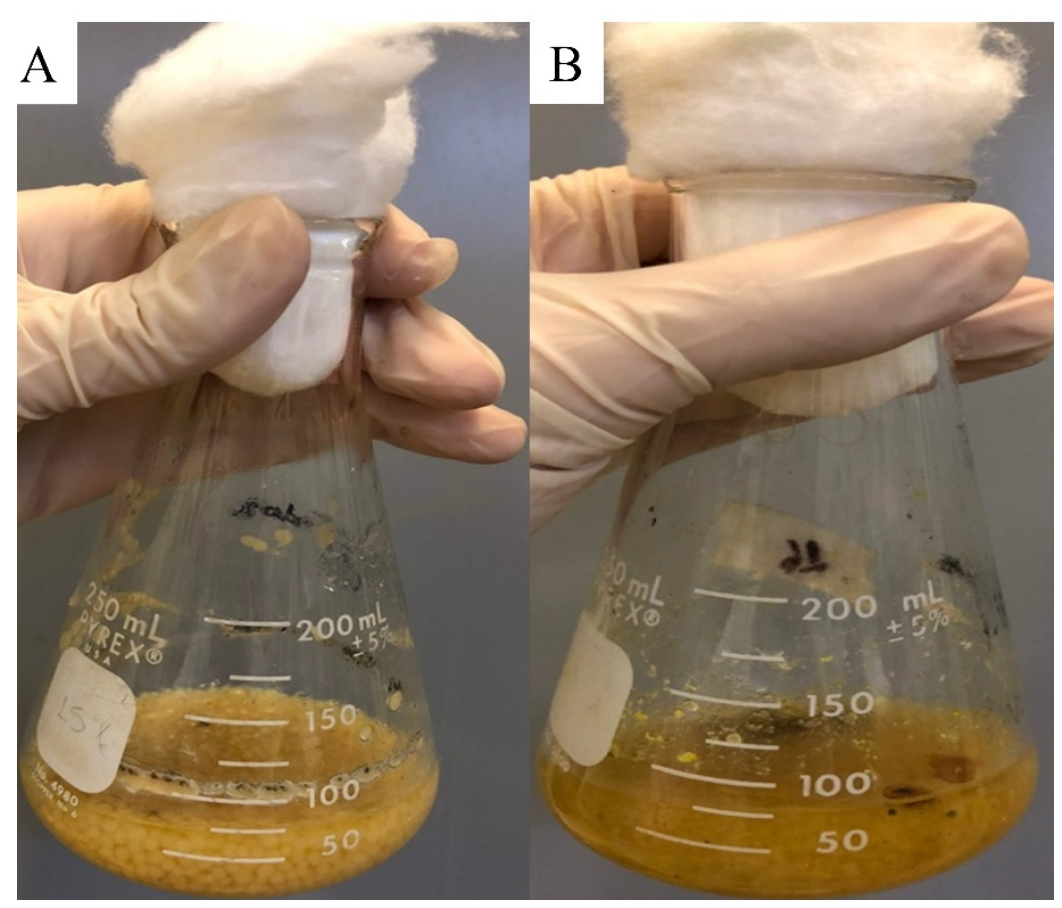

Figura 13. Extrato bruto dos fungos $S$. thermophilum e $A$. phoenicis obtidos após 72 horas de cultivo. (A) Extrato bruto de $S$. thermophilum cultivado em $1 \%$ de óleo de buriti e (B) extrato bruto de (2) A. phoenicis cultivado em 1\% de óleo de girassol.

\subsubsection{Concentração de proteínas do extrato bruto por precipitação por sulfato de amônio e diálise}

Um total de $200 \mathrm{~mL}$ de extrato bruto obtido após fermentação submersa do fungo S. thermophilum em meio SR, suplementado com $1 \%$ de óleo de buriti e do fungo $A$. phoenicis em meio SR, suplementado com 1\% de óleo de girassol, por 72 horas, foi submetido à precipitação com sulfato de amônio, ressuspensão em $200 \mathrm{~mL}$ de tampão McIlvaine $\mathrm{pH} 7$ e, subsequente, diálise. Os resultados foram obtidos através da análise de hidrólise de pNPP.

A partir da análise da Figura 14, foi possível observar a influência positiva do método para o extrato bruto obtido de ambos os fungos, observando-se melhora na atividade enzimática de 3,28 vezes para as lipases do fungo $S$. thermophilum e 1,44 vezes para as lipases do fungo A. phoenicis. 


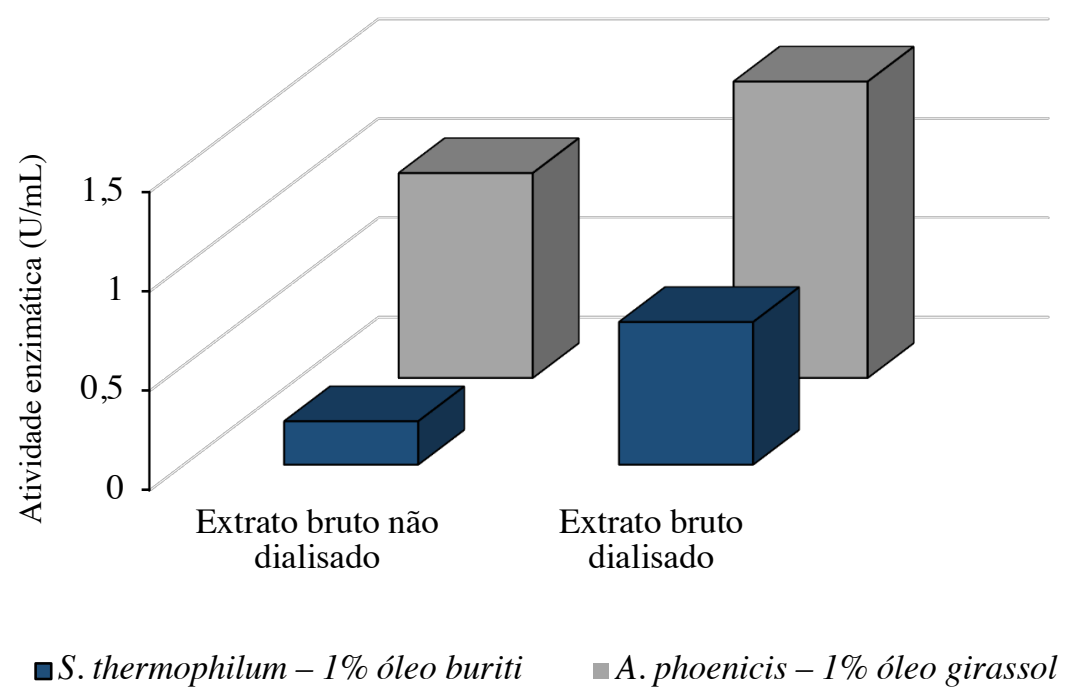

Figura 14. Influência do método de precipitação com sulfato de amônio seguido de diálise para a atividade enzimática. Valores de atividade enzimática em $\mathrm{U} / \mathrm{mL}$ obtidos da lipase de $S$. thermophilum suplementado com $1 \%$ óleo de buriti e $A$. phoenicis suplementado com $1 \%$ óleo de girassol antes e após precipitação.

Ao observar a literatura, Padhiar et al. (2011) seguiram a metodologia de purificação parcial em sulfato de amônio seguida da diálise e observaram um aumento de atividade para as lipases produzidas por Pseudomonas aeruginosa, Candida albicans e A. flavus. Para as lipases produzidas por Pseudomonas marinhas (MSI057) o método promoveu um enriquecimento de 6.62 vezes da atividade enzimática (KIRAN et al., 2008).

Zheng-Yu et al. (2007) purificaram uma lipase de A. niger, utilizando precipitação com sulfato de amônio, seguido por cromatografia em DEAE-Sepharose e filtração em gel em Sephadex G-75, o que resultou em um fator de purificação de 73,71 vezes. Wang et al. (2002) publicou o estudo que inclui metodologia de precipitação com sulfato de amônio 80\%, seguida de filtração em gel em Sephacryl S-100, do extrato bruto de $N$. rileyi, resultando em um fator de purificação de 23,9 vezes.

A partir destes estudos, é possível observar que a precipitação com sulfato de amônio é um procedimento muito utilizado como primeiro passo do processo de purificação. Desta maneira, todo o extrato bruto produzido neste estudo passou pelo processo de precipitação e diálise, a fim de obter a melhor taxa enzimática pelas lipases produzidas pelos fungos selecionados. 
PARTE III - Imobilização e caracterização das lipases de $S$. thermophilum e $A$. phoenicis 


\subsubsection{Termoinativação da lipase de $S$. thermophilum e $A$. phoenicis livre}

Enzimas ao serem submetidas a condições extremas de temperatura e $\mathrm{pH}$ tendem a mudar a sua conformação, podendo ser inativadas. Quando isso acontece diz-se que essas enzimas são instáveis nessas condições, ou seja, não são adequadas para processos que requerem temperaturas e $\mathrm{pH}$ que as inativam (JAENICKE,1991).

Com a finalidade de identificar a estabilidade térmica da lipase livre produzida pelos fungos selecionados, foi realizado o experimento de termoestabilidade nas temperaturas de $40{ }^{\circ} \mathrm{C}, 50{ }^{\circ} \mathrm{C}, 60{ }^{\circ} \mathrm{C}, 70{ }^{\circ} \mathrm{C}$ e $80{ }^{\circ} \mathrm{C}$ por até 48 horas. Nos períodos selecionados, foram retiradas alíquotas para a dosagem enzimática a $50{ }^{\circ} \mathrm{C}$.

A partir dos dados obtidos, foi possível observar uma ativação da lipase do fungo A. phoenicis de $6 \%$ a $40{ }^{\circ} \mathrm{C}$ e de $24 \%$ a $50{ }^{\circ} \mathrm{C}$, com 2 horas de incubação (Figura 15.A). A incubação por 2 horas a $40{ }^{\circ} \mathrm{C}, 50{ }^{\circ} \mathrm{C}$ e $60{ }^{\circ} \mathrm{C}$ resultou em atividades remanescentes aproximada de $106 \%, 124 \%$ e 83,7\%, respectivamente. Em contrapartida, com 4 horas a estabilidade decresceu nas temperaturas de $50{ }^{\circ} \mathrm{C}$ e $60{ }^{\circ} \mathrm{C}$, permanecendo com $52 \%$ e $43,4 \%$ de atividade residual, respectivamente. Em adição, a lipase a $40{ }^{\circ} \mathrm{C}$ foi estável por mais tempo do que a $50^{\circ} \mathrm{C}$ e $60{ }^{\circ} \mathrm{C}$ (Tabela 6). A $70{ }^{\circ} \mathrm{C}$ e $80{ }^{\circ} \mathrm{C}$ a estabilidade da enzima foi menor que 1 hora de incubação.

Para a lipase do fungo $S$. thermophilum a temperatura de $40{ }^{\circ} \mathrm{C}$ proporcionou boa estabilidade (Figura 15.B), mantendo-se com 61,4\% de atividade residual com 4 horas de incubação. Com 24 horas de incubação a atividade residual é inferior a 50\%. Para as temperaturas de $50{ }^{\circ} \mathrm{C} \mathrm{e} 60^{\circ} \mathrm{C}$, a enzima permaneceu estável por 3 horas, após este tempo a atividade residual caiu para $48,2 \%$ e $38,2 \%$, respectivamente. Nas temperaturas de 70 ${ }^{\circ} \mathrm{C}$ e $80^{\circ} \mathrm{C}$, a estabilidade da enzima foi de 30 minutos de incubação.

A Tabela 6 demonstra os valores de $t_{50}$ em minutos, que corresponde ao tempo necessário para que se mantenha $50 \%$ da atividade enzimática. 

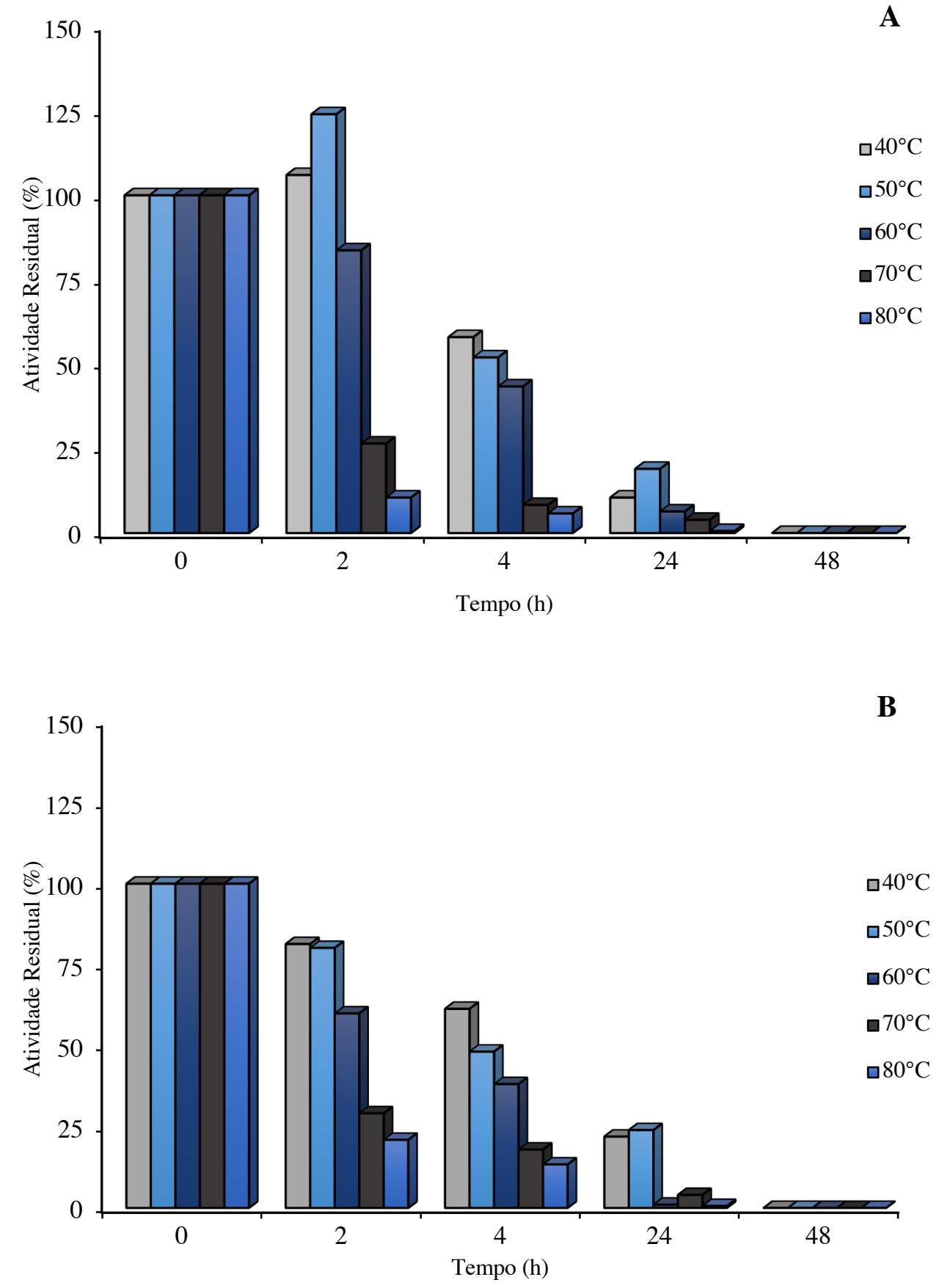

Figura 15. Estabilidade térmica da lipase livre. (A) A. phoenicis e (B) S. thermophilum em fermentação submersa com meio SR e 1\% de óleo de Girassol e óleo de Buriti, respectivamente. Foi realizada a dosagem enzimática (pNPP) das alíquotas de extrato bruto retiradas nos períodos de $0,2,4,24$ e 48 horas. 
Tabela 6. Valores de $t_{50}$ em minutos da lipase livre de $A$. phoenicis e $S$. thermophilum em diferentes temperaturas.

\begin{tabular}{ccc}
\hline \multirow{2}{*}{$\begin{array}{c}\text { Temperatura } \\
\left({ }^{\circ} \mathrm{C}\right)\end{array}$} & \multicolumn{2}{c}{ Parâmetro t50 (min) } \\
\cline { 2 - 3 } & A. phoenicis & S. thermophilum \\
\hline $\mathbf{4 0}$ & 270 & 240 \\
$\mathbf{5 0}$ & 240 & 180 \\
$\mathbf{6 0}$ & 180 & 180 \\
$\mathbf{7 0}$ & 60 & 30 \\
$\mathbf{8 0}$ & 30 & 30 \\
\hline
\end{tabular}

As aplicações biotecnológicas alvo deste trabalho requerem uma estabilidade físico-química considerável da enzima, para conduzir os experimentos que demandam um tempo de reação por até 24 horas. Portanto, as enzimas livres de ambos os fungos analisados se tornam inviáveis para conduzir tais experimentos, por perderem mais que $50 \%$ da sua atividade em 24 horas de incubação.

Uma forma de aumentar a estabilidade das enzimas é através da técnica de imobilização (GUPTA et al., 2004). Portanto, foi realizado o teste de imobilização para verificar a estabilidade da enzima em diferentes condições e concluir sobre sua viabilidade nos experimentos a serem conduzidos para conclusão deste trabalho.

\subsubsection{Ensaio de imobilização da lipase em suportes sólidos hidrofóbicos e iônicos}

\subsubsection{Ensaio de imobilização para enzimas produzidas por A. phoenicis}

Na imobilização ocorre a interação da enzima com um dado suporte, o que pode promover uma alteração conformacional da proteína, resultando em propriedades catalíticas e estabilidade diferentes (SECUNDO, 2013; TELLO et al., 2016).

A imobilização em suportes hidrofóbicos foi feita nas matrizes comerciais Octylsepharose, Butyl-sepharose e Sepabeads C-18 (Figura 16). A imobilização em suportes de interação iônica foi testada nas resinas MANAE-agarose, PEI-agarose e Duolite (Figura 17). A imobilização ocorreu como descrito em Materiais e Métodos. O estudo de imobilização foi realizado em diferentes períodos, permitindo a construção dos perfis de imobilização, que correlacionaram a atividade relativa do sobrenadante e do derivado, e 
o respectivo tempo de imobilização.

Analisando os resultados obtidos por 24 horas de reação de imobilização, verificou-se (Tabela 7) que nos suportes Butyl-sepharose, Sepabeads C-18, PEI-agarose e Duolite, a retenção de lipase produzida por A. phoenicis presente no extrato bruto foi na faixa de $70 \%$ a $80 \%$ e para MANAE-agarose foi de aproximadamente $48 \%$ de retenção. Por outro lado, o suporte Octyl-sepharose teve retenção de aproximadamente 100\% da enzima. Em 24 horas de imobilização a atividade relativa, em relação aos 104 U totais iniciais, foi superior a 100\%. Esse acréscimo aproximado de $17 \%$ indicou o fenômeno de hiperativação após a imobilização da lipase.

De acordo com Mateo et al. (2007), as lipases ao serem imobilizadas em suportes hidrofóbicos permanecem com a sua conformação aberta, facilitando o acesso do substrato ao sítio ativo, aumentando a taxa de reação de hidrólise.

O suporte MANAE-agarose, além de reter a menor porcentagem $(47,87 \%$ do inicial) dentre os demais suportes, exibiu a maior perda de atividade relativa. Indicando menor estabilidade e interação neste suporte, visto que apenas $26,67 \%$ foi mantida.

Analisando a Figura 16. A, no derivado em suporte Octyl é observado o fenômeno da hiperativação a partir de 5 horas de imobilização, atingindo valor máximo (115 U/mg) em 24 horas de imobilização. No suporte Butyl (Figura 16. B), a retenção no suporte foi o segundo maior valor encontrado $(78,70 \%)$, porém sua atividade relativa alcançou o valor de aproximadamente $60 \%$ de atividade relativa, após 24 horas de imobilização. O derivado em Sepabeads (Figura 16. C) apresentou atividade relativa alta, de $87 \%$ a $94 \%$, entre os períodos de 3 horas a 5 horas de imobilização.

Analisando o perfil de imobilização do derivado nos suportes iônicos (Figura 17), o derivado em MANAE-agarose (Figura 17. A) e PEI-agarose (Figura 17. B) apresentaram os menores valores de atividade relativa de $26,67 \%$ e $12,43 \%$ respectivamente, em 24 horas de imobilização (Tabela 7).

Em adição, o derivado em Duolite (Figura 17. C) mesmo apresentando uma boa taxa de retenção $(76,55 \%)$, proporcionou valores de atividade relativa de aproximadamente $30 \%$ após 24 horas de ensaio de imobilização. Este é um resultado não satisfatório diante do obtido para os suportes hidrofóbicos.

Em conclusão, para o prosseguimento dos demais experimentos foram 
selecionados os três melhores derivados. Desta maneira, os suportes Octyl, Butyl e Sepabeads foram selecionados para a lipase de A. phoenicis.

Em relação ao tempo ideal para imobilização da lipase de $A$. phoenicis, os suportes Octyl e Butyl atingiram seu nível máximo de retenção de 98,83\% e 78,70, respectivamente em 24 horas de imobilização. O derivado em Sepabeads atingiu nível máximo de imobilização entre 3 e 5 horas.

Tabela 7. Parâmetros de imobilização de lipase do fungo $A$. phoenicis após 24 horas. Reação de imobilização consistiu na mistura de $1 \mathrm{~g}$ de suporte com $104 \mathrm{U}$ totais de hidrólise de pNPP, provenientes do extrato bruto do crescimento.

\begin{tabular}{ccc}
\hline Suporte & ${\text { Retenção }(\mathbf{\%})^{\mathbf{a}}}^{\mathbf{a}}$ & Atividade Relativa (\%) $^{\mathbf{b}}$ \\
\hline Octyl-Sepharose & 98,83 & 115,54 \\
Butyl-Sepharose & 78,70 & 59,50 \\
Sepabeads C-18 & 76,55 & 78,80 \\
MANAE-agarose & 47,87 & 26,67 \\
PEI-agarose & 73,52 & 12,43 \\
Duolite & 76,55 & 30,87 \\
\hline
\end{tabular}

Parâmetros: ${ }^{\mathrm{a}}$ corresponde a proporção entre a unidade enzimática total do sobrenadante retida pelo suporte após 24 horas e os valores de $104 \mathrm{U}$ totais iniciais, em porcentagem. ${ }^{\mathbf{b}}$ definida pela razão entre a unidade enzimática total presente no suporte, após 24 horas de imobilização, em relação aos valores de 104 U totais iniciais. 

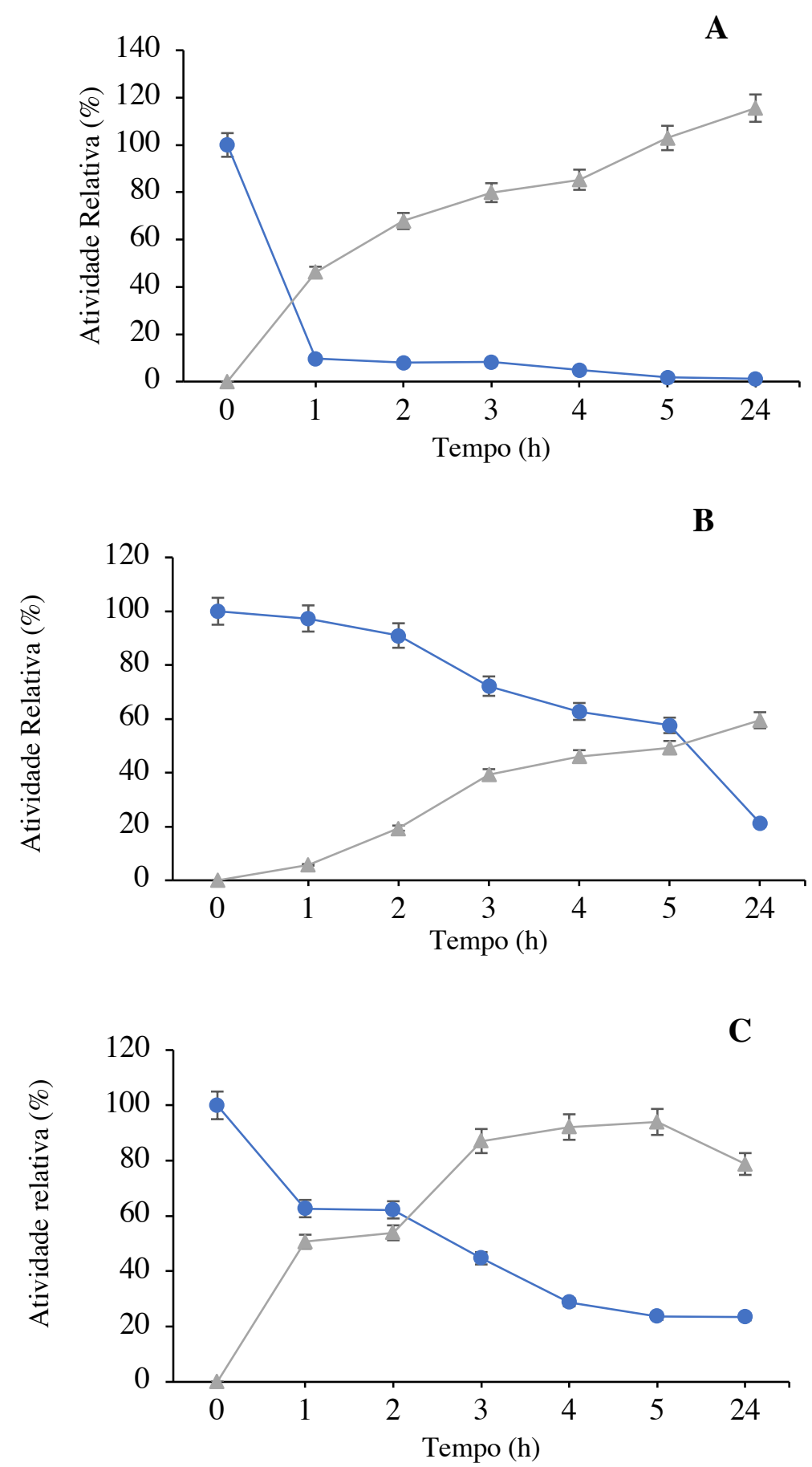

Figura 16. Ensaio de imobilização da lipase de $A$. phoenicis em suportes hidrofóbicos. (A) Octyl-sepharose; (B) Butyl-sepharose; (C) Sepabeads C-18. Para o experimento de imobilização, $1 \mathrm{~g}$ de suporte foi misturado a um volume de $38 \mathrm{~mL}$ de extrato bruto de $A$. phoenicis (104 U totais) e $2 \mathrm{~mL}$ de tampão fosfato de sódio $50 \mathrm{mM}, \mathrm{pH} \mathrm{7,0.} \mathrm{Os} \mathrm{valores} \mathrm{de} \mathrm{atividade} \mathrm{relativa} \mathrm{do}$ sobrenadante e do derivado foram expressos em relação ao valor de $104 \mathrm{U}$ totais, correspondendo a $100 \%$ da atividade relativa. $(\bullet)$ atividade relativa do sobrenadante e $(\Delta)$ atividade relativa do derivado. 

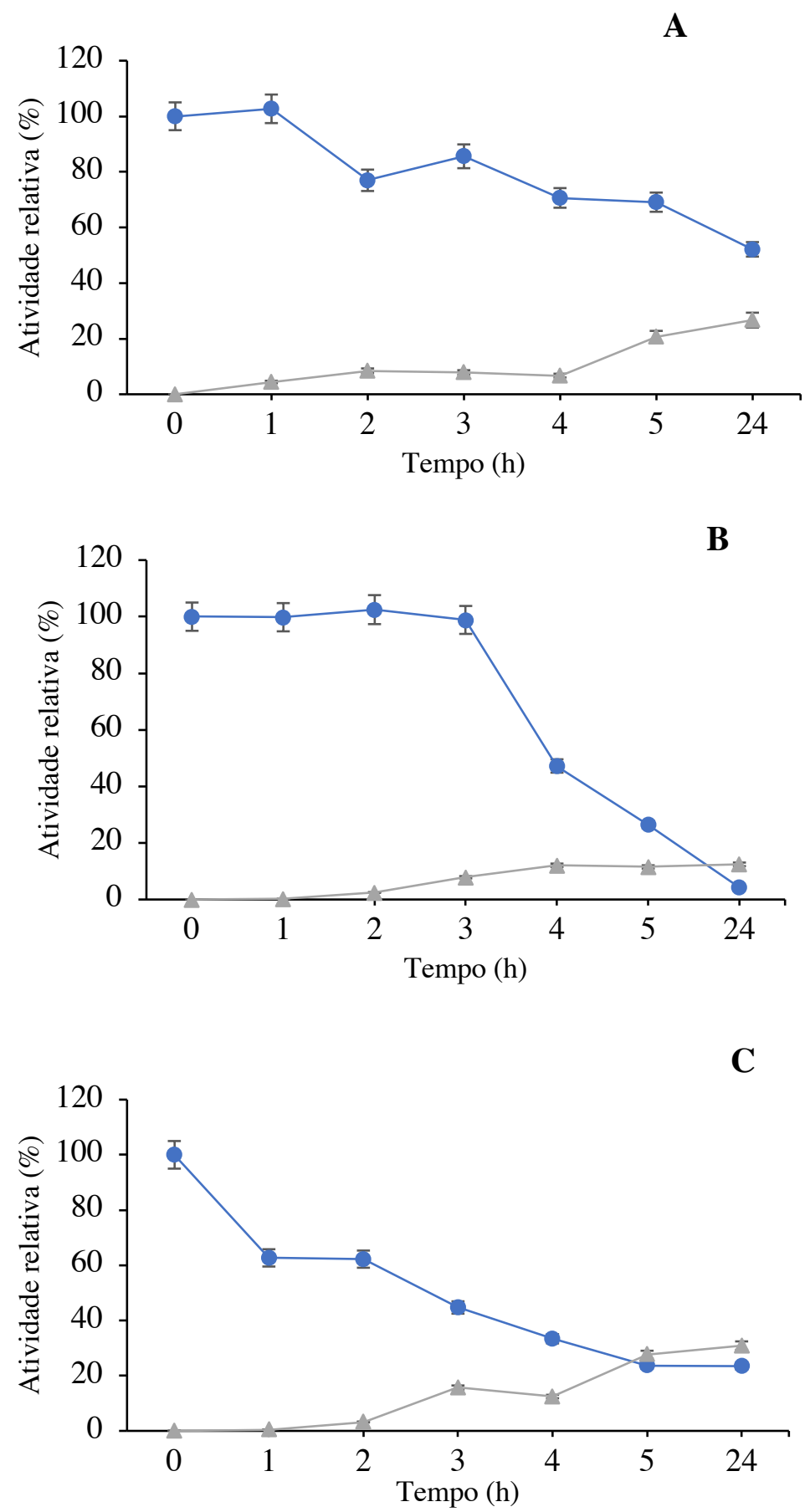

Figura 17. Ensaio de imobilização da lipase de $A$. phoenicis em suportes iônicos. (A) MANAE-agarose; (B) PEI-agarose e (C) Duolite. Para o experimento de imobilização, $1 \mathrm{~g}$ de suporte foi misturado a um volume de $38 \mathrm{~mL}$ de extrato bruto de A. phoenicis (104 U totais) e 2 $\mathrm{mL}$ de tampão fosfato de sódio $50 \mathrm{mM}, \mathrm{pH} 7,0$. Os valores de atividade relativa do sobrenadante e do derivado foram expressos em relação ao valor de 104 U totais, correspondendo a $100 \%$ da atividade relativa. $(\bullet)$ atividade relativa do sobrenadante e $(\Delta)$ atividade relativa do derivado. 


\subsubsection{Ensaio de imobilização para enzimas produzidas por $S$. thermophilum}

A imobilização das lipases de S. thermophilum foi procedida, conforme descrito em materiais e métodos, em suportes hidrofóbicos comerciais Octyl- sepharose, Butylsepharose e Sepabeads C-18 (Figura 18); e nos suportes de interação iônica MANAEagarose, PEI-agarose e Duolite (Figura 19). A dosagem enzimática (pNPP) foi realizada com as amostras retiradas de sobrenadante e suspensão durantes os períodos de 1, 2, 3, 4, 5 e 24 horas de ensaio de imobilização.

Analisando os resultados obtidos, em 24 horas de imobilização, verificou-se que nos suportes Octyl, Butyl, Sepabeads e Duolite, a retenção da lipase produzida por $S$. thermophilum presente no extrato bruto foi de aproximadamente $100 \%$. A menor taxa de retenção foi para o derivado em PEI-agarose com apenas 38,27\% da atividade inicial mantida (Tabela 8). Cada suporte apresentou uma diferente porcentagem de atividade relativa.

Ao observar os dados obtidos na Tabela 8 para os suportes Sepabeads e Duolite, em relação aos 83 U totais iniciais, a atividade relativa da suspensão foi superior a $100 \%$ em 24 horas de imobilização. Esse acréscimo aproximado de 13\% para lipase imobilizada em Sepabeads e 16\% para lipase imobilizada em Duolite indicou um fenômeno de hiperativação após a imobilização da lipase.

Algumas lipases apresentam grandes porcentagens de hiperativação, podendo ser de 1,0 a 100 vezes superior à sua atividade inicial. Nos estudos de Cunha et al. (2009) e Palomo et al. (2002) as lipases de Penicillium simplicissimum e Mucor miehei apresentaram altas taxas de hiperativação quando imobilizadas.

O estudo de imobilização foi realizado em diferentes períodos, permitindo a construção dos perfis de imobilização, que correlacionaram a atividade relativa do sobrenadante e do derivado, e o respectivo tempo de imobilização (Figura 18 e 19).

Para o derivado em Octyl (Figura 18. A) é possível observar um aumento da atividade do derivado de aproximadamente $40 \%$ entre 5 horas a 24 horas de imobilização. A retenção no suporte foi o segundo maior valor encontrado $(88,51 \%)$, indicando o tempo ideal de 24 horas para imobilização da lipase de $S$. thermophilum neste suporte.

O derivado em Butyl (Figura 18. B) apresentou baixo valor de atividade relativa (aproximadamente 35\%), sendo este um resultado não satisfatório. Ao analisar o 
resultado para o suporte Sepabeads (Figura 18. C), 100\% da atividade relativa é alcançada em 5 horas de ensaio de imobilização. Em adição, é observado o fenômeno da hiperativação em 24 horas de imobilização.

Analisando os resultados para o derivado em suportes iônicos (Figura 19), observa-se que em MANAE-agarose (Figura 19. A) e PEI-agarose (Figura 19. B) os valores de atividade relativa da suspensão não se apresentam satisfatórios, diante dos valores obtidos para os outros suportes em 24 horas de ensaio de imobilização. Atingindo os valores máximos de aproximadamente $50 \%$ e $40 \%$ de atividade, respectivamente. No suporte Duolite (Figura 19. C) observa-se o fenômeno de hiperativação a partir de 4 horas de imobilização onde a atividade relativa atinge valor de $111 \%$, sendo máxima (116\%) em 24 horas de imobilização.

Tabela 8. Parâmetros de imobilização de lipase do fungo $S$. thermophilum após 24 horas. Reação de imobilização consistiu na mistura de $1 \mathrm{~g}$ de suporte com $83 \mathrm{U}$ totais de hidrólise de pNPP, provenientes do extrato bruto do crescimento.

\begin{tabular}{ccc}
\hline Suporte & ${\text { Retenção }(\%)^{\mathbf{a}}}^{\mathbf{a}}$ & Atividade Relativa (\%) $^{\mathbf{b}}$ \\
\hline Octyl-Sepharose & 96,99 & 88,51 \\
Butyl-Sepharose & 95,41 & 34,44 \\
Sepabeads C-18 & 98,59 & 113,15 \\
MANAE-agarose & 85,65 & 47,84 \\
PEI-agarose & 67,18 & 38,27 \\
Duolite & 98,73 & 116,26
\end{tabular}

Parâmetros: ${ }^{a}$ corresponde a proporção entre a unidade enzimática total do sobrenadante retida pelo suporte após 24 horas e os valores de $83 \mathrm{U}$ totais iniciais, em porcentagem. ${ }^{\mathbf{b}}$ definida pela razão entre a unidade enzimática total presente no suporte, após 24 horas de imobilização, em relação aos valores de 83 U totais iniciais. 

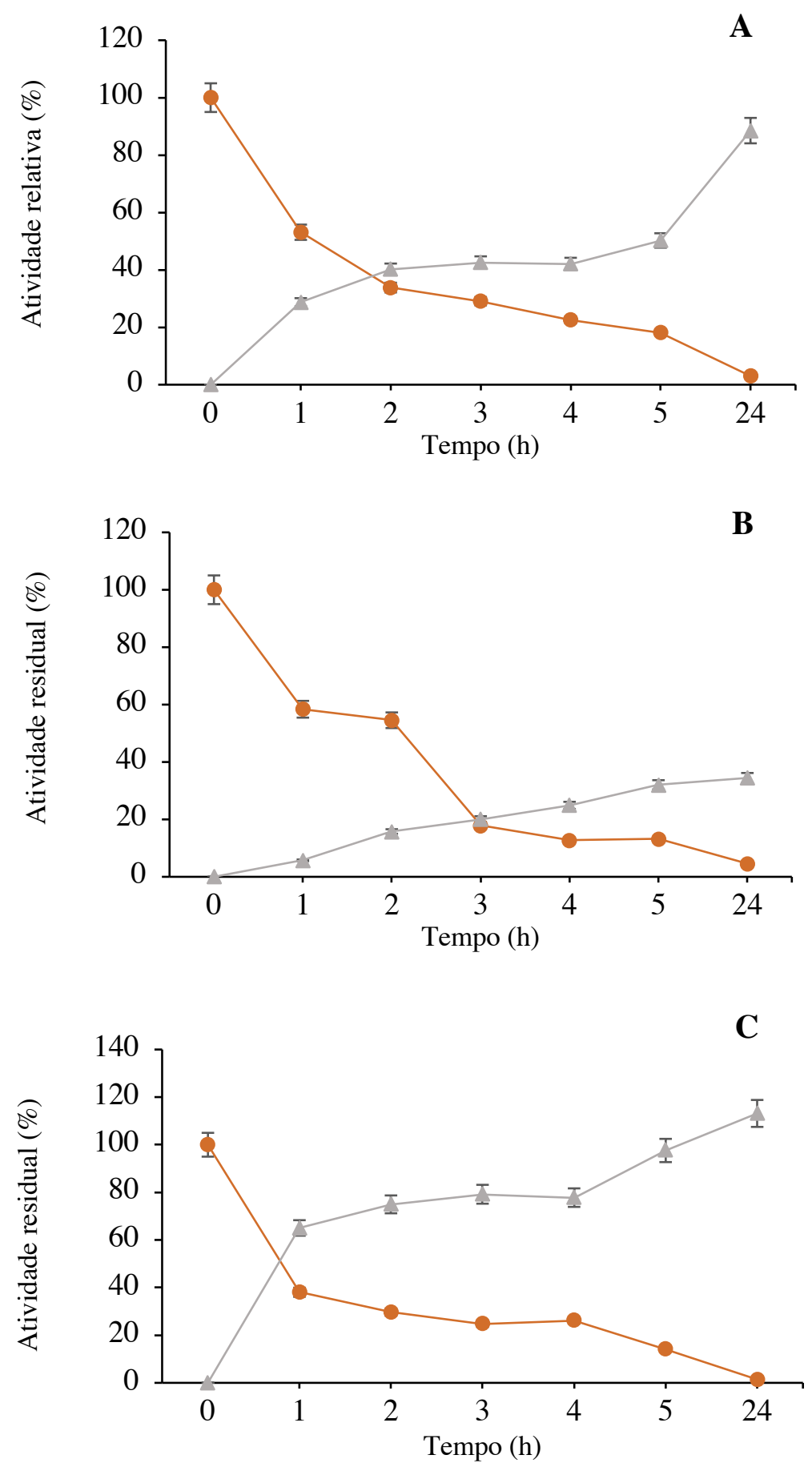

Figura 18. Ensaio de imobilização da lipase de $S$. thermophilum em suportes hidrofóbicos. (A) Octyl-sepharose; (B) Butyl-sepharose; (C) Sepabeads C-18. Para o experimento de imobilização, $1 \mathrm{~g}$ de suporte foi misturado a um volume de $38 \mathrm{~mL}$ de extrato bruto de $S$. thermophilum (83 U totais) e $2 \mathrm{~mL}$ de tampão fosfato de sódio $50 \mathrm{mM}, \mathrm{pH} 7,0$. Os valores de atividade relativa do sobrenadante e do derivado foram expressos em relação ao valor de $83 \mathrm{U}$ totais, correspondendo a $100 \%$ da atividade relativa. $(\bullet)$ atividade relativa do sobrenadante e $(\triangle)$ atividade relativa do derivado. 

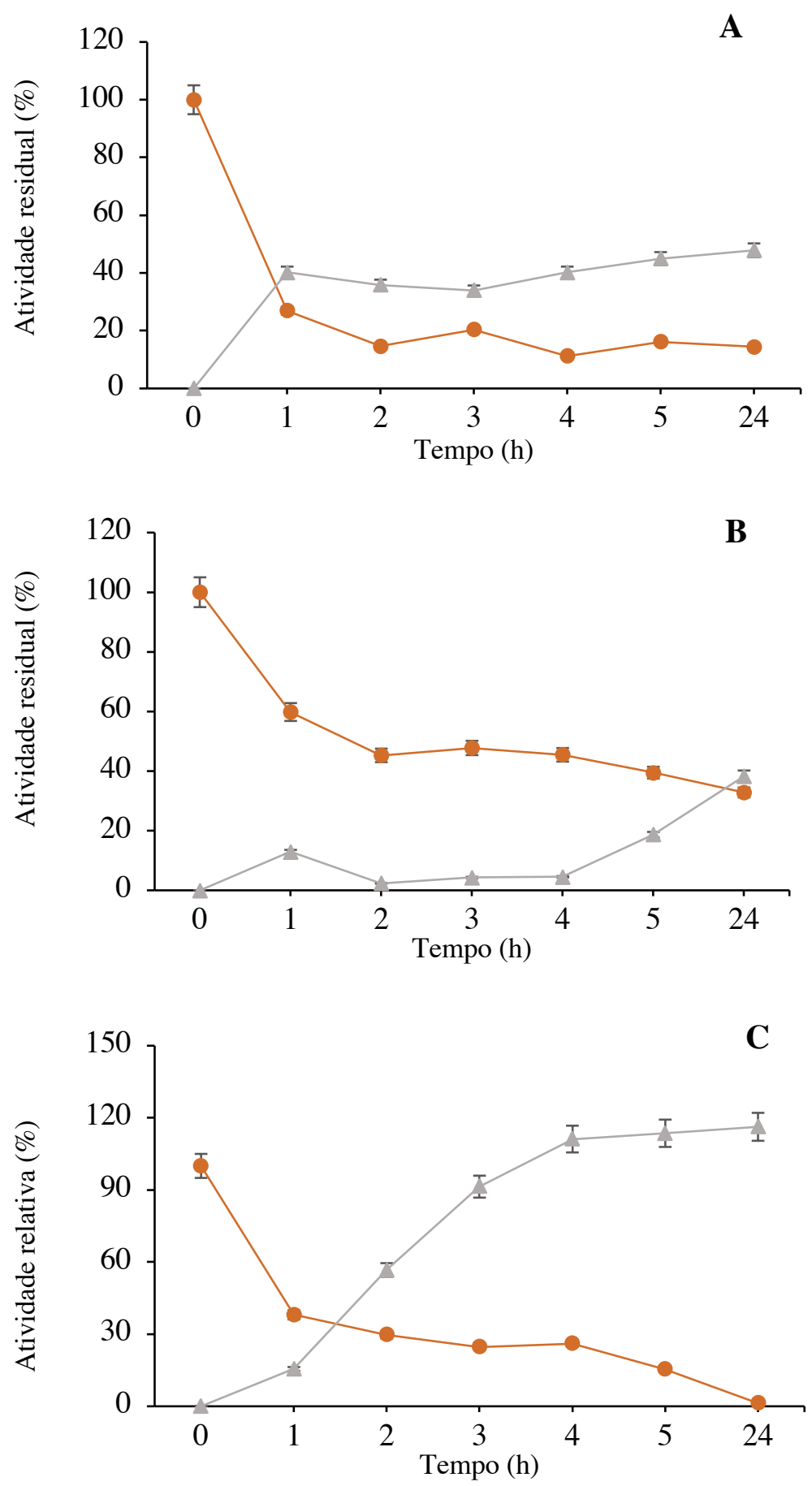

Figura 19. Ensaio de imobilização da lipase de $S$. thermophilum em suportes iônicos. (A) MANAE-agarose; (B) PEI-agarose e (C) Duolite. Para o experimento de imobilização, $1 \mathrm{~g}$ de suporte foi misturado a um volume de $38 \mathrm{~mL}$ de extrato bruto de $S$. thermophilum ( $83 \mathrm{U}$ totais) e $2 \mathrm{~mL}$ de tampão fosfato de sódio $50 \mathrm{mM}, \mathrm{pH} 7,0$. Os valores de atividade relativa do sobrenadante e do derivado foram expressos em relação ao valor de $83 \mathrm{U}$ totais, correspondendo a $100 \%$ da atividade relativa. $(\bullet)$ atividade relativa do sobrenadante e $(\Delta)$ atividade relativa do derivado. 
Em conclusão, os suportes Butyl, MANAE-agarose e PEI-agarose (Figura 19) apresentaram os menores valores de retenção e atividade relativa após 24 de imobilização, demonstrando a baixa estabilidade da lipase quando imobilizada nestes suportes.

Desta maneira, para as lipases de $S$. thermophilum foram selecionados os três melhores derivados: Octyl, Sepabeads e Duolite foram selecionados. Observou-se que em 24 horas de imobilização atingiu-se o nível máximo de atividade e retenção, sendo este o tempo estabelecido como o ideal para o ensaio de imobilização.

\subsubsection{Estabilidade dos derivados}

A estabilidade é um parâmetro importante que deve ser analisado pós imobilização, pois a maioria das enzimas adquirem um aumento da estabilidade frente a diferentes condições físico-químicas, como temperatura, $\mathrm{pH}$ e solvente, quando comparada à estabilidade da enzima livre (FERNANDEZ-LORENTE et al., 2008).

\subsubsection{Ensaios de estabilidade das lipases de A. phoenicis imobilizadas}

\subsection{Estabilidade térmica dos derivados nos suportes selecionados}

Uma solução de cada derivado foi mantida em diferentes temperaturas por até 48 horas. O experimento iniciou-se com a mistura de $40 \mathrm{mg}$ de derivado com $2 \mathrm{~mL}$ de tampão McIlvaine pH 6,0 e $1 \mathrm{~mL}$ de extrato bruto com $2 \mathrm{~mL}$ de tampão McIlvaine $\mathrm{pH}$ 6,0. As soluções foram incubadas nas temperaturas $40,50,60,70$ e $80^{\circ} \mathrm{C}$, onde alíquotas de 0,5 $\mathrm{mL}$ foram retiradas e submetidas à hidrólise de pNPP. Os suportes foram selecionados para realização dos testes de estabilidade de acordo com os resultados obtidos anteriormente nos testes de imobilização para as lipases. Sendo para lipase de $A$. phoenicis, os suportes: Octyl-sepharose (Figura 20), Butyl-sepharose (Figura 21) e Sepabeads C-18 (Figura 22). Analisando os perfis observou-se que dependendo do tipo de suporte, a estabilidade nos períodos estudados foi diferente.

A partir da análise da Figura 20, comparando-se o derivado em Octyl e a lipase livre de A. phoenicis, observou-se um aumento na estabilidade da enzima nas temperaturas de $40{ }^{\circ} \mathrm{C}$ (Figura 20. A) e $50{ }^{\circ} \mathrm{C}$ (Figura 20. B). Ressaltando-se que o fenômeno de hiperativação iniciou-se a 1 hora de incubação, mantendo-se por 24 horas, a $40{ }^{\circ} \mathrm{C}$. A $50{ }^{\circ} \mathrm{C}$ a hiperativação apresentou-se maior, atingindo uma taxa aproximadamente 55\% maior, quando comparada com a enzima livre. Em adição, nesta 
temperatura o derivado manteve-se com atividade superior a $100 \%$ entre 1 hora a 48 horas de incubação. Na temperatura de $60{ }^{\circ} \mathrm{C}$ (Figura 20. C) o derivado foi a estável por até 150 minutos, já a $70{ }^{\circ} \mathrm{C}$ (Figura 20. D) o derivado atingiu a t 50 com menos de 60 minutos de incubação. Desta maneira, o derivado em Octyl a $50{ }^{\circ} \mathrm{C}$ foi o que apresentou melhor estabilidade e hiperativação.
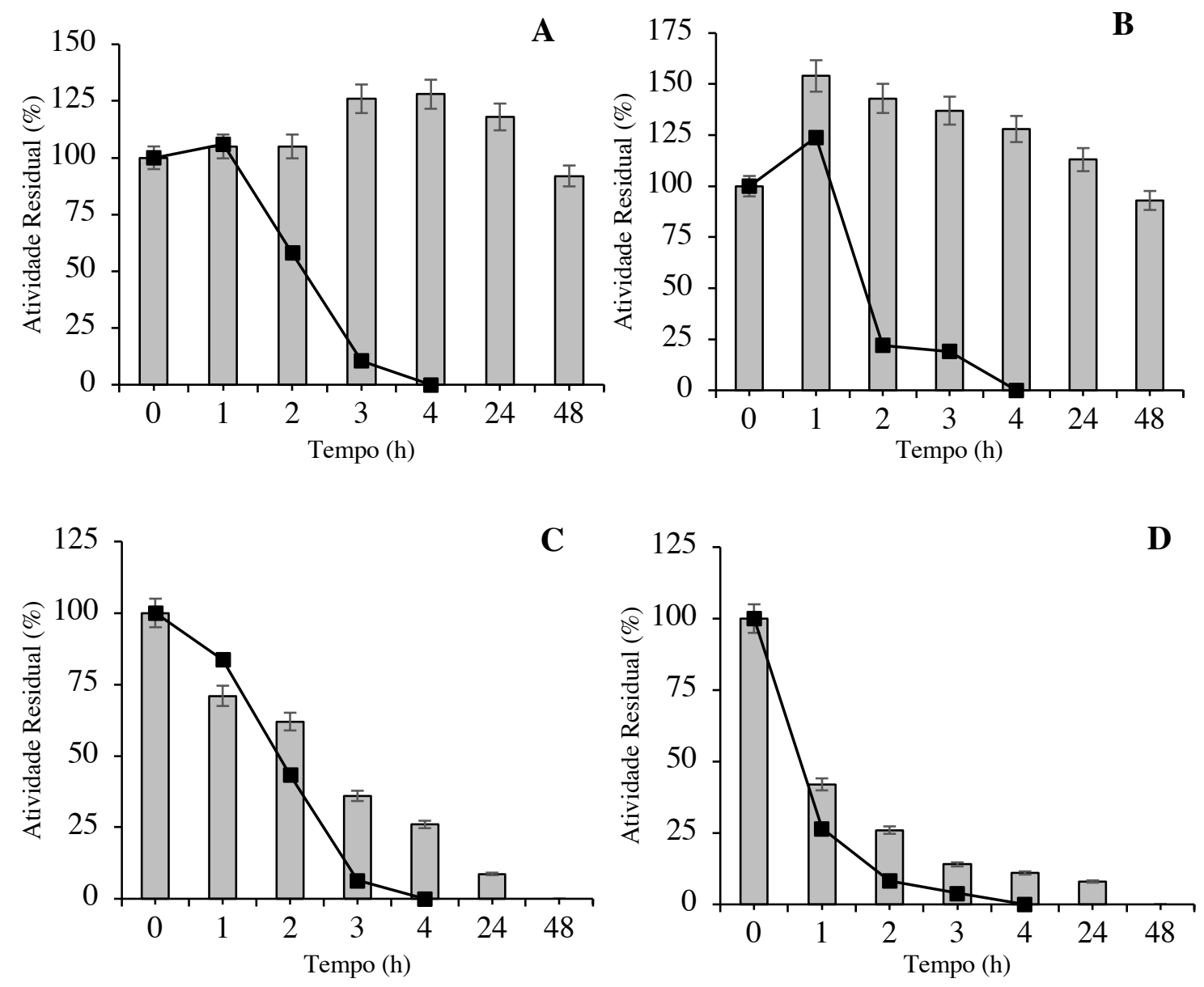

Figura 20. Estabilidade térmica dos derivados de A. phoenicis em Octyl-sepharose. Para tal, $40 \mathrm{mg}$ de derivados foram suspensos em $2 \mathrm{~mL}$ de tampão McIlvaine $\mathrm{pH}$ 6,0 e incubados em diferentes temperaturas. Para comparação $1 \mathrm{~mL}$ de extrato bruto foram adicionados a $1 \mathrm{ml}$ de tampão Mcllvaine pH 6,0 e incubados em diferentes temperaturas. (A) $40{ }^{\circ} \mathrm{C}$; (B) $50{ }^{\circ} \mathrm{C}$; (C) 60 ${ }^{\circ} \mathrm{C}$ e (D) $70{ }^{\circ} \mathrm{C}$. Valores de atividade para cada período foram expressos em atividade relativa em relação à atividade dos derivados no tempo inicial do experimento. O resultado obtido para temperatura de $80^{\circ} \mathrm{C}$ foram omitidos, por apresentar resultados semelhantes a temperatura de 70 ${ }^{\circ} \mathrm{C}$. Legenda: ( $\square$ ) derivado e ( $\left.\mathbf{\square}\right)$ enzima livre.

A partir da análise da Figura 21, comparando-se o derivado em Butyl e a lipase de $A$. phoenicis não imobilizada, a estabilidade não foi melhorada ao imobilizar a enzima neste suporte. Foi registrado mais de 50\% de perda da atividade inicial do derivado logo nas primeiras horas de experimentos em todas as temperaturas testadas. Portanto, o 
suporte Butyl foi descartado para prosseguimento dos experimentos.
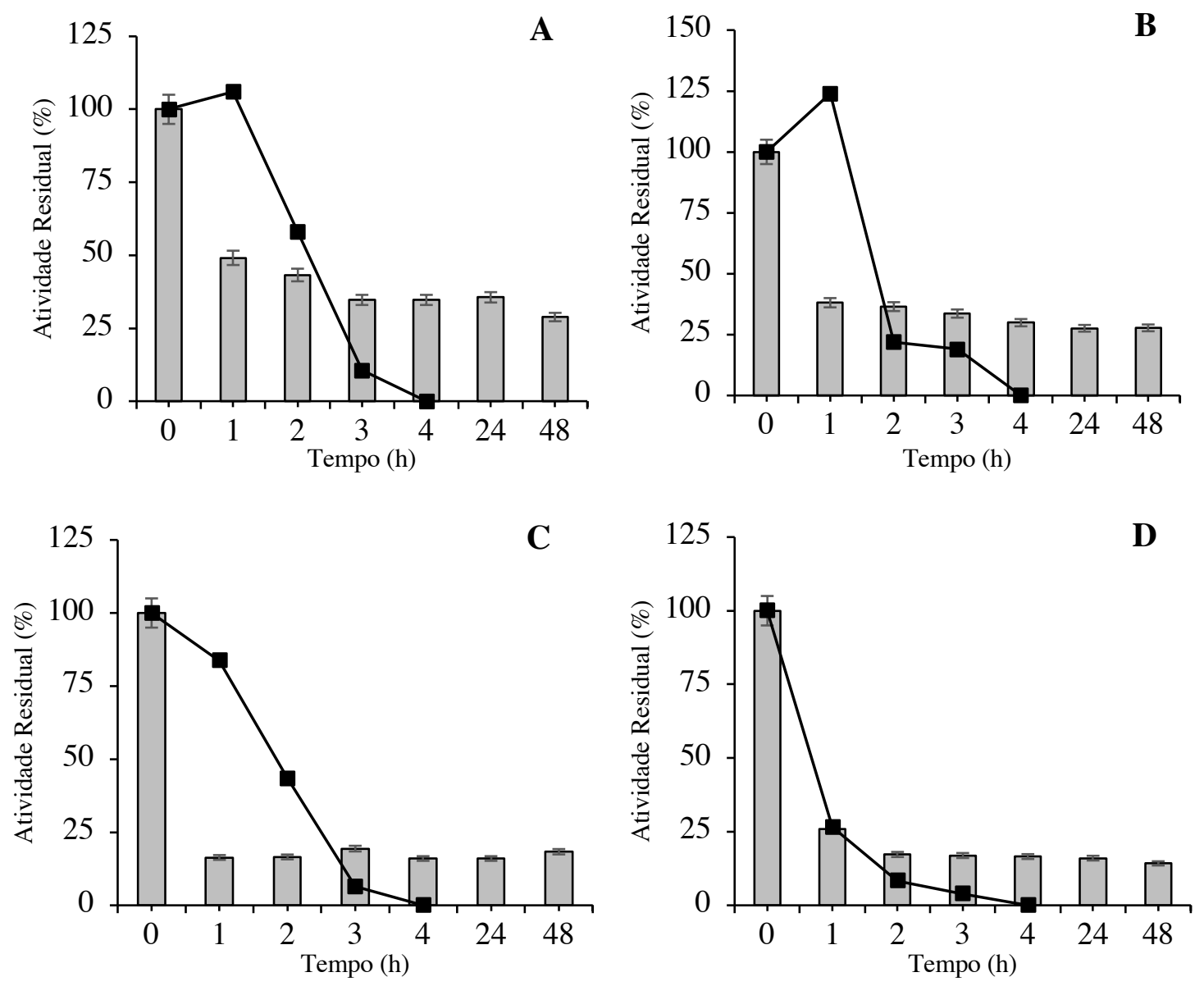

Figura 21. Estabilidade térmica dos derivados de A. phoenicis em Butyl-sepharose. Para tal, $40 \mathrm{mg}$ de derivados foram suspensos em $2 \mathrm{~mL}$ de tampão Mcllvaine $\mathrm{pH}$ 6,0 e incubados em diferentes temperaturas. Para comparação $1 \mathrm{~mL}$ de extrato bruto foram adicionados a $1 \mathrm{ml} \mathrm{de}$ tampão Mcllvaine pH 6,0 e incubados em diferentes temperaturas. (A) $40{ }^{\circ} \mathrm{C}$; (B) $50{ }^{\circ} \mathrm{C}$; (C) 60 ${ }^{\circ} \mathrm{C}$ e (D) $70{ }^{\circ} \mathrm{C}$. Valores de atividade para cada período foram expressos em atividade relativa em relação à atividade dos derivados no tempo inicial do experimento. $\mathrm{O}$ resultado obtido para temperatura de $80^{\circ} \mathrm{C}$ foram omitidos, por apresentar resultados semelhantes a temperatura de 70 ${ }^{\circ} \mathrm{C}$. Legenda: ( $\square$ ) derivado e ( $\left.\mathbf{\square}\right)$ enzima livre.

Analisando a Figura 22, observa-se que o derivado em Sepabeads, a $40{ }^{\circ} \mathrm{C}$ (Figura 22. A) e $50^{\circ} \mathrm{C}$ (Figura 22. B), apresenta maior estabilidade térmica quando comparado a enzima livre. Em ambas as temperaturas, a atividade residual se manteve acima de 50\% da atividade inicial por até 48 horas, destacando a eficiência da imobilização para manter a enzima ativa por longos períodos. Nas temperaturas de $60^{\circ} \mathrm{C}$ (Figura 22. C) e $70{ }^{\circ} \mathrm{C}$ (Figura 22. D) a t $t_{50}$ foi alcançada em período menor que 60 minutos de incubação. 

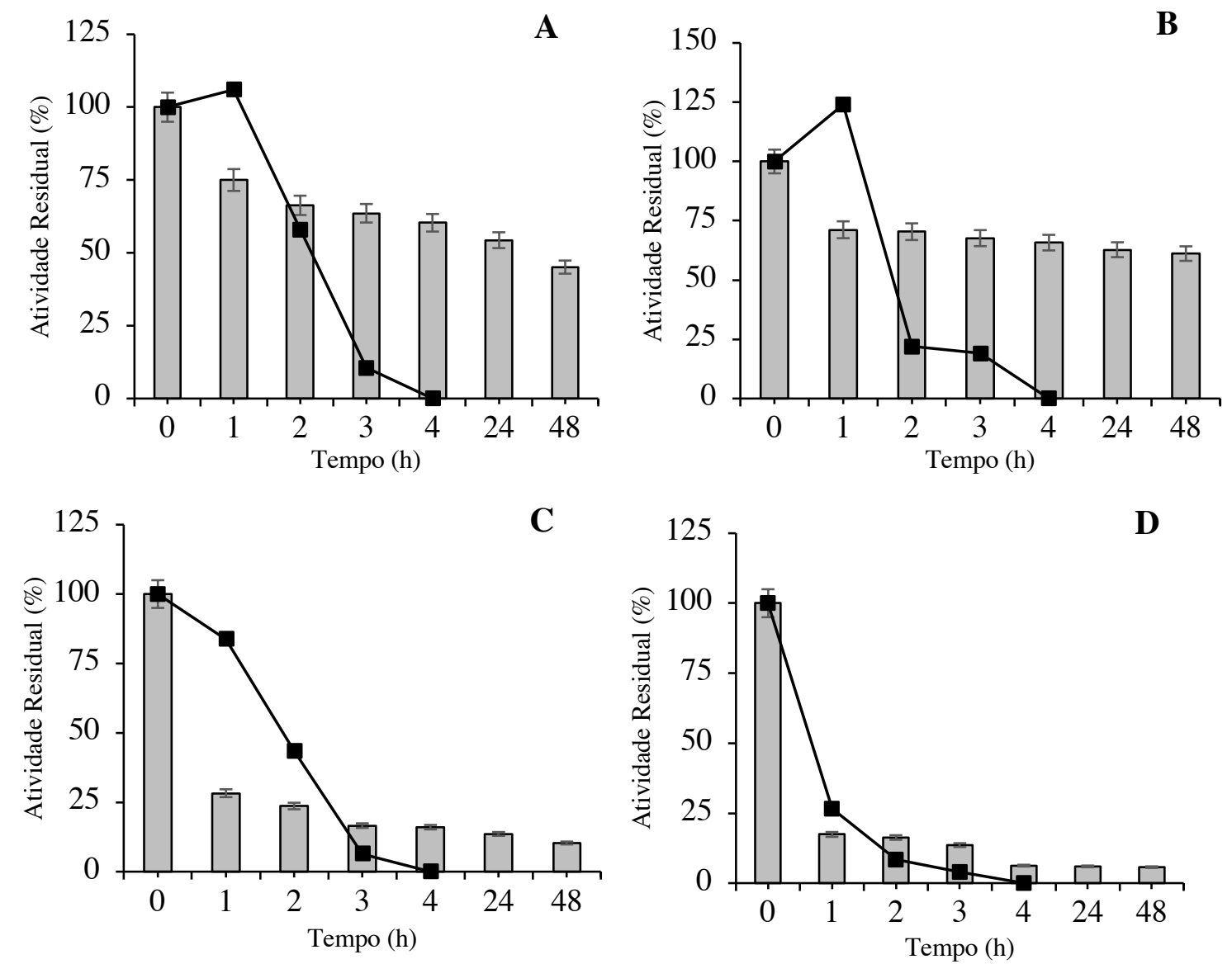

Figura 22. Estabilidade térmica dos derivados de $\boldsymbol{A}$. phoenicis em Sepabeads C-18. Para tal, $40 \mathrm{mg}$ de derivados foram suspensos em $2 \mathrm{~mL}$ de tampão Mcllvaine $\mathrm{pH}$ 6,0 e incubados em diferentes temperaturas. Para comparação $1 \mathrm{~mL}$ de extrato bruto foram adicionados a $1 \mathrm{ml}$ de tampão Mcllvaine pH 6,0 e incubados em diferentes temperaturas. (A) $40{ }^{\circ} \mathrm{C}$; (B) $50{ }^{\circ} \mathrm{C}$; (C) 60 ${ }^{\circ} \mathrm{C}$ e (D) $70{ }^{\circ} \mathrm{C}$. Valores de atividade para cada período foram expressos em atividade relativa em relação à atividade dos derivados no tempo inicial do experimento. $\mathrm{O}$ resultado obtido para temperatura de $80{ }^{\circ} \mathrm{C}$ foram omitidos, por apresentar resultados semelhantes a temperatura de 70 ${ }^{\circ} \mathrm{C}$. Legenda: ( $\square$ ) derivado e ( $\square$ ) enzima livre.

Para todos os suportes analisados acima, registrou-se queda na estabilidade a 70 ${ }^{\circ} \mathrm{C}$ e $80{ }^{\circ} \mathrm{C}$. Em $70{ }^{\circ} \mathrm{C}$, todos os derivados mantiveram apenas $10 \%-20 \%$ da atividade inicial. Houve completa inativação do derivado a $80{ }^{\circ} \mathrm{C}$ (dados não mostrados), com 48 horas de incubação. Os resultados obtidos para temperatura de $80{ }^{\circ} \mathrm{C}$ não foram mostrados, por apresentar resultados semelhantes a temperatura de $70{ }^{\circ} \mathrm{C}$.

Através da análise da Tabela 9, é possível visualizar os resultados de estabilidade de acordo com o parâmetro t50. A enzima livre é capaz de manter metade do valor da sua atividade residual por até 115 minutos, incubada nas temperaturas de 40 e $50{ }^{\circ} \mathrm{C}$. 
Tabela 9. Valores de $t_{50}$ em minutos dos derivados de $A$. phoenicis em diferentes temperaturas. Esses valores foram determinados em suspensão de $40 \mathrm{mg}$ de derivado em $2 \mathrm{~mL}$ de tampão McIlvaine pH 6,0 e 1 mL de extrato bruto em 1 mL de tampão McIlvaine pH 6,0.

\begin{tabular}{lcccc}
\hline \multirow{2}{*}{ Suportes } & \multicolumn{4}{c}{ Parâmetro t $\mathbf{5 0}_{\mathbf{0}}$ (min) } \\
\cline { 2 - 4 } & $40^{\circ} \mathrm{C}$ & $50^{\circ} \mathrm{C}$ & $60^{\circ} \mathrm{C}$ & $70^{\circ} \mathrm{C}$ \\
\hline Octyl- sepharose & $>48 \mathrm{~h}^{*}$ & $>48 \mathrm{~h}^{*}$ & 150 & 50 \\
Butyl- sepharose & 60 & 30 & 10 & 10 \\
Sepabeads C-18 & $>48 \mathrm{~h}^{*}$ & $>48 \mathrm{~h}^{*}$ & 30 & 10 \\
Enzima Livre & 120 & 60 & 60 & 30 \\
\hline * horas \\
$\begin{array}{l}\text { Sinal de maior }(>) \text { indica a impossibilidade de determinar com exatidão visto à limitação dos períodos } \\
\text { avaliados. }\end{array}$
\end{tabular}

Conclui-se que para a lipase de A. phoenicis a imobilização nos suportes hidrofóbicos, Octyl-sepharose e Sepabeads, proporcionou um aumento significativo na estabilidade térmica, apresentando atividade residual acima de $50 \%$ por até 48 horas. Adicionalmente, a temperatura de $50{ }^{\circ} \mathrm{C}$ o derivado apresenta maior estabilidade e atividade enzimática, observando-se hiperativação da enzima no caso do derivado em Octyl.

\subsection{Estabilidade em pH dos derivados nos suportes selecionados}

Da mesma forma que o observado no estudo de estabilidade térmica dos derivados, observou-se uma melhora na estabilidade ao $\mathrm{pH}$ da lipase de A. phoenicis imobilizada nos suportes analisados, em relação a enzima livre. Os valores de $\mathrm{pH}$ analisados para os derivados foram: 6, 7, 8 e 9; por até 48 horas de incubação a $40^{\circ} \mathrm{C}$.

Analisando o perfil de estabilidade da enzima livre, observa-se o fenômeno de ativação em pH 6, com aumento de aproximadamente 10\% de atividade residual. Em pH 7 houve um aumento de aproximadamente 5\% com 2 horas de incubação (Figura 23. C). O derivado Octyl apresentou atividade residual acima de 50\% quando incubado em pH 6 (Figura 23. A), 7 (Figura 23. B), 8 (Figura 23. C) e 9 (Figura 23. D), por 48 horas, A estabilidade a pHs altos como 8 e 9 é uma característica interessante, que pode sugerir uma aplicação desse derivado em processos que utilizam essa faixa de pHs.

Este resultado demonstra a eficiência do suporte Octyl em estabilizar a enzima de 
A. phoenicis. A hiperativação do derivado foi verificada em $\mathrm{pH} 6$, com aumento da atividade residual em torno de $20 \%$ entre 1 e 2 horas de incubação, se apresentando maior que o ocorrido na enzima livre.
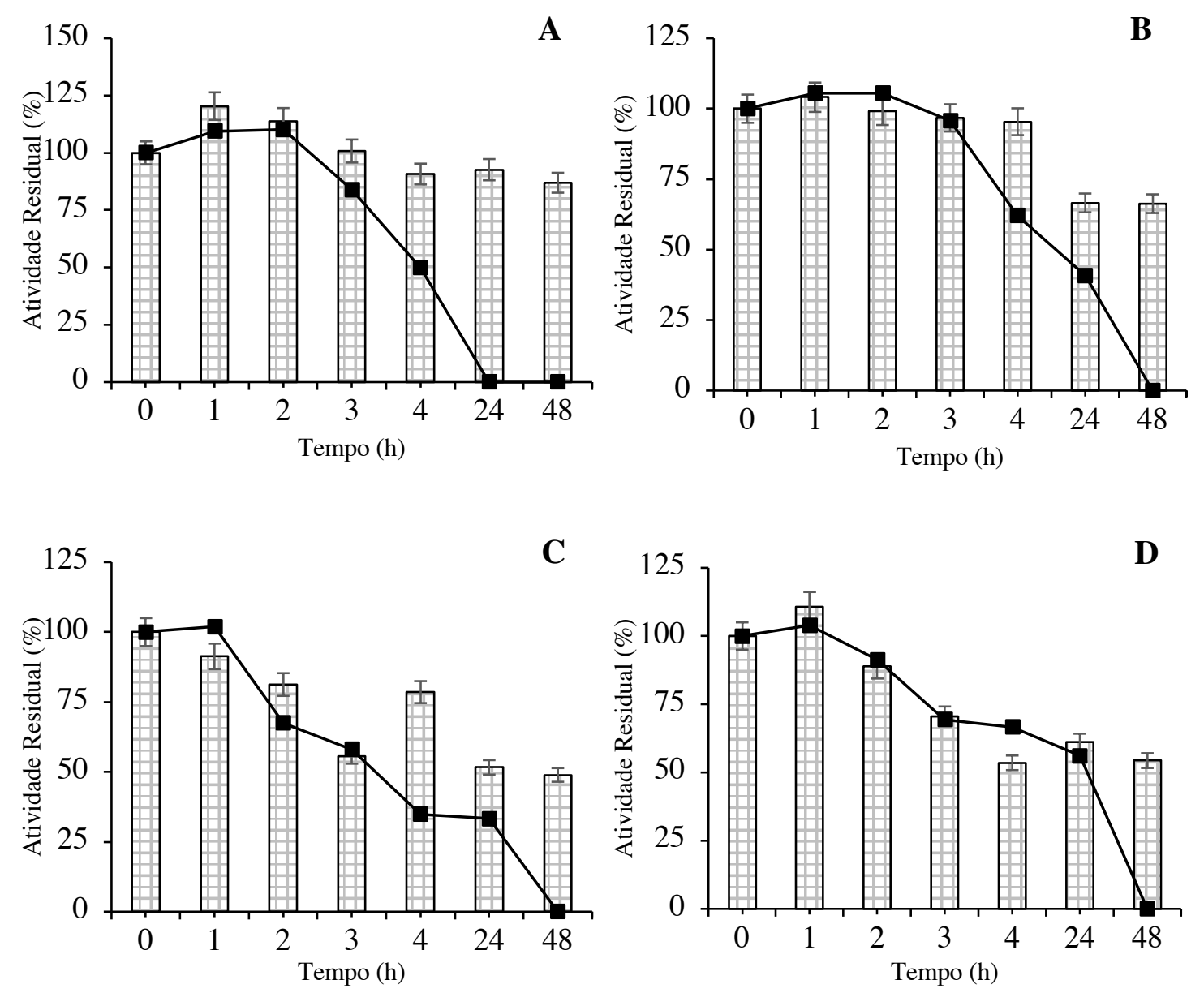

Figura 23. Estabilidade ao $\mathbf{p H}$ da lipase de $A$. phoenicis imobilizada em Octyl-sepharose. Para tal, $40 \mathrm{mg}$ de derivados foram suspensos em $2 \mathrm{~mL}$ de tampão Mcllvaine (A) pH 6; (B) pH 7 e (C) $\mathrm{pH} 8$ e (D) em tampão glicina pH 9, incubados a $40^{\circ} \mathrm{C}$. Os resultados foram expressos em atividade relativa calculada em relação à atividade dos derivados no tempo inicial do experimento. Legenda: (国) derivado e (ロ) enzima livre.

Ao analisar a enzima imobilizada no suporte Butyl (Figura 24), verifica-se que a atividade residual em pH 6 (Figura 24. A) foi superior a 50\% da atividade inicial por até 48 horas. Em pH 7 (Figura 24. B), a t t50 $_{0}$ foi atingida por volta de 4 horas de incubação. Em pH 8 (Figura 24. C) e 9 (Figura 24. D) verifica-se a baixa estabilidade do derivado. Além disso, a enzima livre foi mais estável que o derivado Butyl na faixa de $\mathrm{pH}$ testada. 

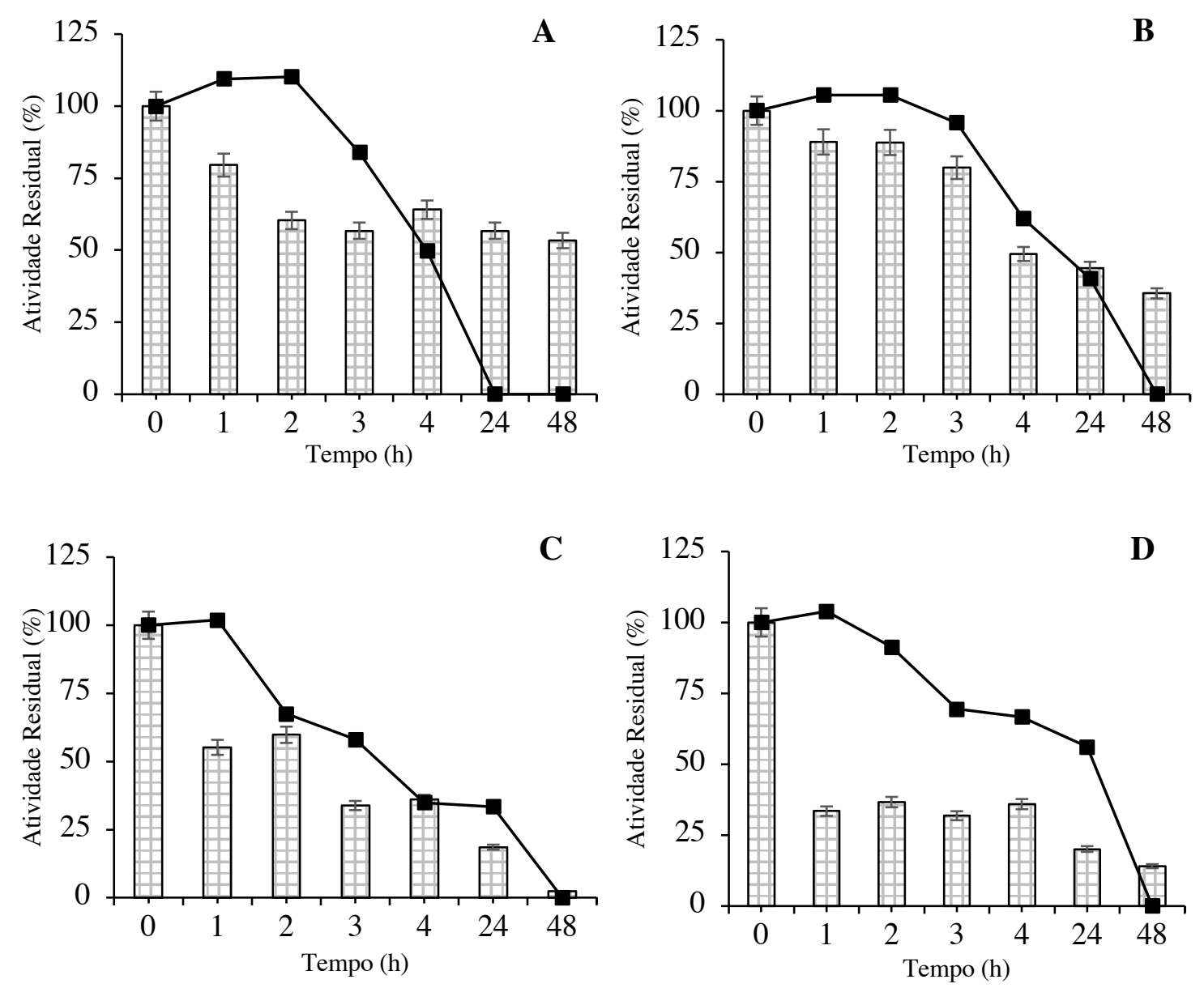

Figura 24. Estabilidade ao pH dos derivados de A. phoenicis em Butyl-sepharose. Para tal, $40 \mathrm{mg}$ de derivados foram suspensos em $2 \mathrm{~mL}$ de tampão McIlvaine (A) $\mathrm{pH}$ 6; (B) $\mathrm{pH} 7 \mathrm{e}$ (C) $\mathrm{pH}$ 8 e em (D) tampão glicina $\mathrm{pH} 9$, incubados a $40{ }^{\circ} \mathrm{C}$. Os resultados foram expressos em atividade relativa calculada em relação à atividade dos derivados no tempo inicial do experimento. Legenda: (圈) derivado e (ロ) enzima livre.

O derivado de Sepabeads apresentou maior estabilidade, com 24 horas de incubação, em tampão pH 6 (Figura 25. A) e não houve ativação da enzima. Em pH 7 (Figura 25. B), a estabilidade apresenta perfil diferente, pois a atividade residual se manteve acima de 50\% do valor inicial por até 100 minutos. Em pH 8 (Figura 25. C) a $\mathrm{t}_{50}$ foi atingida por volta de horas de incubação. Por fim, em pH 9 (Figura 25. D) a atividade residual apresenta queda de mais de 50\% logo na $1^{\mathrm{a}}$ hora de incubação. Com exceção do derivado em Octyl (Figura 23), os demais suportes não apresentaram estabilidade satisfatória nos $\mathrm{pH} 8$ e 9. 

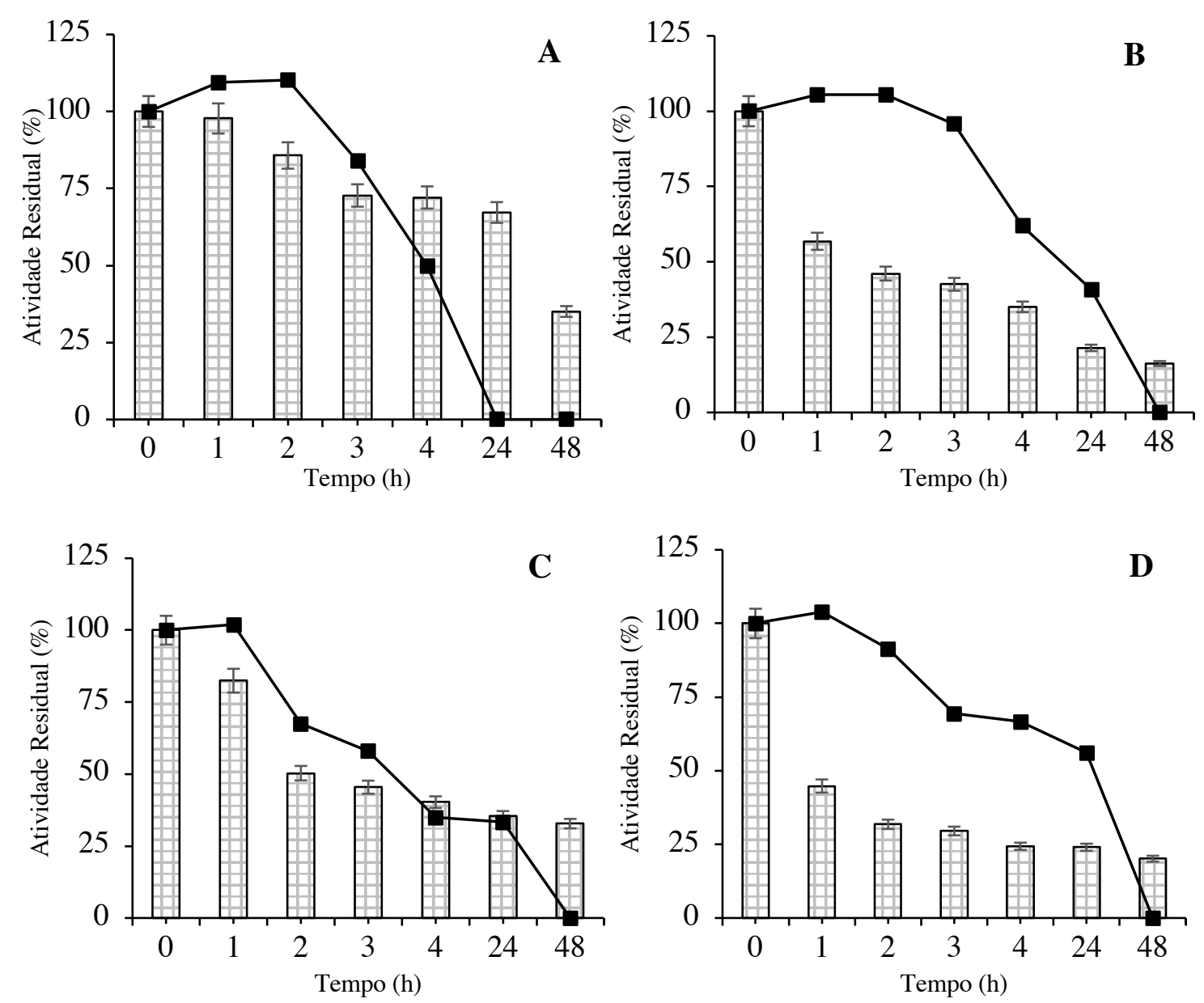

Figura 25. Estabilidade ao pH dos derivados de A. phoenicis em Sepabeads C-18. Para tal, $40 \mathrm{mg}$ de derivados foram suspensos em $2 \mathrm{~mL}$ de tampão McIlvaine (A) $\mathrm{pH}$ 6; (B) $\mathrm{pH}$ 7; (C) pH 8 e em (D) tampão glicina $\mathrm{pH} 9$, incubados a $40^{\circ} \mathrm{C}$. Os resultados foram expressos em atividade relativa calculada em relação à atividade dos derivados no tempo inicial do experimento. Legenda: (国) estabilidade do derivado e ( $\mathbf{\square})$ enzima livre.

Através da análise da Tabela 10 é possível identificar os resultados de estabilidade de acordo com o parâmetro t50. A enzima livre permanece com $50 \%$ da sua atividade residual, por menos que 24 horas de incubação em pH 6, 7 e 9. Apresentando baixa estabilidade em $\mathrm{pH} 8$, onde $50 \%$ da sua atividade residual é atingida em 230 minutos de incubação. 
Tabela 10. Valores de $\mathbf{t}_{50} \mathrm{em}$ minutos dos derivados de $\boldsymbol{A}$. phoenicis em diferentes pHs. Esses valores foram determinados em solução de $40 \mathrm{mg}$ de derivado em $2 \mathrm{~mL}$ de tampão mantido a 40 ${ }^{\circ} \mathrm{C}$.

\begin{tabular}{ccccc}
\hline \multirow{2}{*}{ Suportes } & \multicolumn{4}{c}{ Parâmetro t50 (min) } \\
\cline { 2 - 5 } & $\mathrm{pH} 6$ & $\mathrm{pH} \mathrm{7}$ & $\mathrm{pH} 8$ & $\mathrm{pH} 9$ \\
\hline Octyl- sepharose & $>48 \mathrm{~h}^{*}$ & $>48 \mathrm{~h}^{*}$ & $>48 \mathrm{~h}^{*}$ & $>48 \mathrm{~h}^{*}$ \\
Butyl- sepharose & $>48 \mathrm{~h}^{*}$ & 96 & 150 & 30 \\
Sepabeads C-18 & $24-48 \mathrm{~h}^{*}$ & 90 & 120 & 30 \\
Enzima Livre & 300 & $4-24 \mathrm{~h}^{*}$ & 210 & $24 \mathrm{~h}$ \\
\hline
\end{tabular}

*h: horas

Sinal de maior $(>)$ indica a impossibilidade de determinar com exatidão visto à limitação dos períodos avaliados.

Conclui-se que para os derivados estudados, os suportes Octyl-sepharose (Figura 23) e Sepabeads (Figura 25) estabilizaram melhor a enzima em relação ao pH do meio, quando comparado a enzima livre. Com destaque para o derivado em Octyl, frente aos demais suportes analisados, que em pH 6 verificou-se o fenômeno de hiperativação entre 1 a 2 horas de incubação. Desta maneira, o suporte Octyl apresentou os melhores resultados de estabilidade, tanto em temperatura quanto em $\mathrm{pH}$

\subsubsection{Ensaios de estabilidade das lipases de $S$. thermophilum imobilizadas}

\subsubsection{Termoinativação dos derivados nos suportes selecionados}

Uma solução de cada derivado da lipase de $S$. thermophilum foi mantida em diferentes temperaturas por até 48 horas. $\mathrm{O}$ experimento iniciou-se com a mistura de 40 mg de derivado e $1 \mathrm{~mL}$ de extrato bruto com $2 \mathrm{~mL}$ de tampão McIlvaine $\mathrm{pH}$ 6,0. As temperaturas analisadas foram $40{ }^{\circ} \mathrm{C}, 50{ }^{\circ} \mathrm{C}, 60{ }^{\circ} \mathrm{C}, 70{ }^{\circ} \mathrm{C}$ e $80^{\circ} \mathrm{C}$. Os suportes foram selecionados para realização dos testes de estabilidade, de acordo com os resultados obtidos anteriormente nos testes de imobilização, sendo eles: Octyl-sepharose (Figura 26), Sepabeads C-18 (Figura 27) e Duolite (Figura 28).

A partir da análise da Figura 26, observou-se, em comparação a lipase livre, um aumento na estabilidade térmica do derivado em Octyl. Houve uma perda de $30 \%$ na atividade residual com 1 hora de incubação, a $40^{\circ} \mathrm{C}$ (Figura 26. A). Nesta temperatura a 
atividade residual alcançou t t50 $_{0} \mathrm{em} 24$ horas de incubação. Para a temperatura de $50{ }^{\circ} \mathrm{C}$ (Figura 26. B), houve uma perda de aproximadamente 50\% da atividade residual no com 1 hora de incubação, a qual se manteve constante por até 3 horas de incubação. Nas temperaturas $60^{\circ} \mathrm{C}$ e $70^{\circ} \mathrm{C}$ (Figura 26. C e D) a t to foi atingida antes de 1 hora.
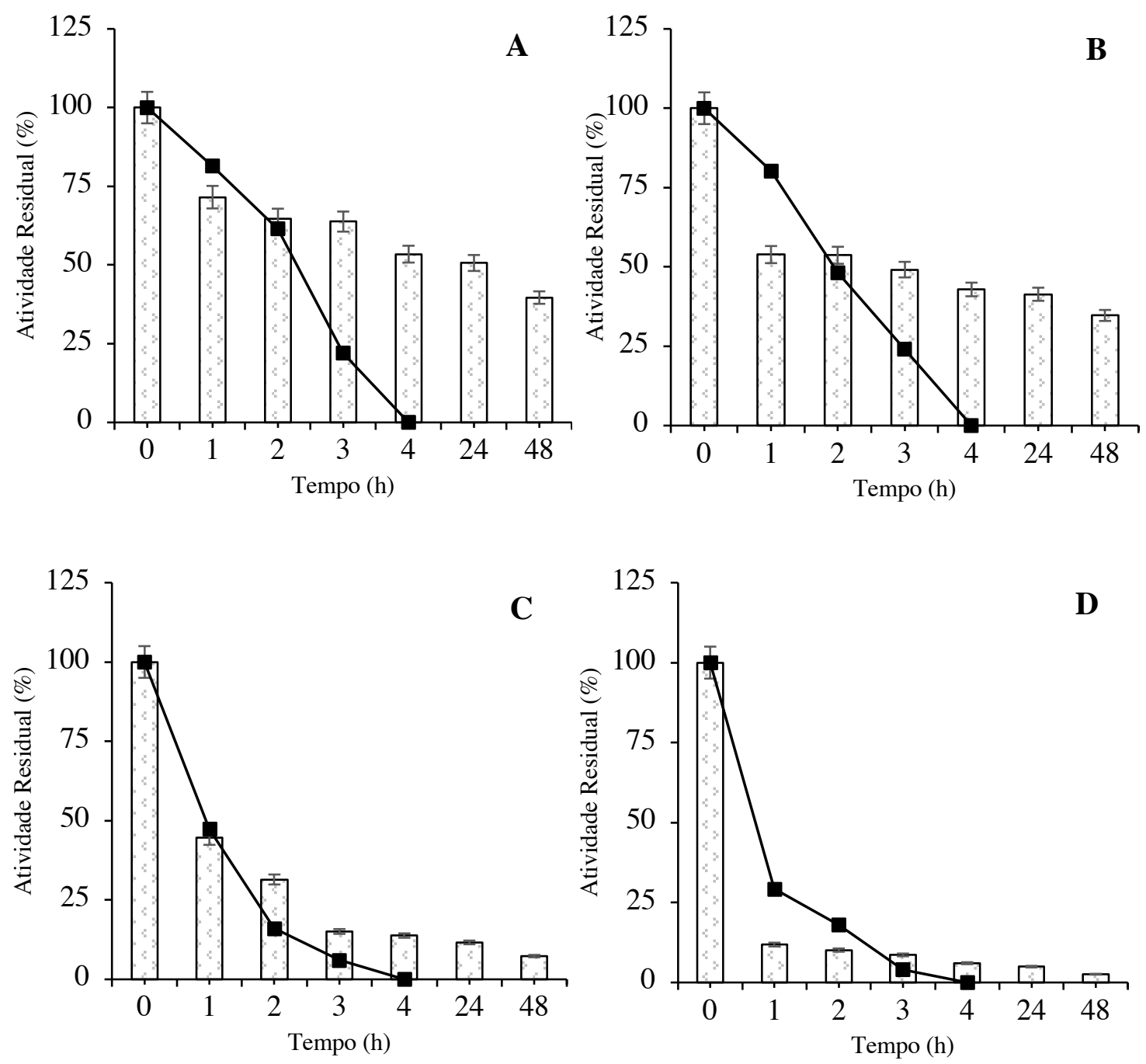

Figura 26. Estabilidade térmica dos derivados de $S$. thermophilum em Octyl-sepharose. Para tal, $40 \mathrm{mg}$ de derivados foram suspensos em $2 \mathrm{~mL}$ de tampão McIlvaine $\mathrm{pH}$ 6,0 e incubados em diferentes temperaturas. Para comparação $1 \mathrm{~mL}$ de extrato bruto foram adicionados a $1 \mathrm{ml}$ de tampão Mcllvaine pH 6,0 e incubados em diferentes temperaturas. (A) $40{ }^{\circ} \mathrm{C}$; (B) $50{ }^{\circ} \mathrm{C}$; (C) 60 ${ }^{\circ} \mathrm{C}$ e (D) $70^{\circ} \mathrm{C}$. Valores de atividade para cada período foram expressos em atividade relativa em relação à atividade dos derivados no tempo inicial do experimento. O resultado obtido para temperatura de $80^{\circ} \mathrm{C}$ foram omitidos, por apresentar resultados semelhantes a temperatura de 70 ${ }^{\circ} \mathrm{C}$ Legenda: ( $\mid$ | $)$ derivado e ( $\left.\mathbf{\square}\right)$ enzima livre.

Para o derivado em Sepabeads (Figura 27), houve aumento da estabilidade térmica, principalmente nas temperaturas de $40^{\circ} \mathrm{C}$ (Figura 27. A) e $50^{\circ} \mathrm{C}$ (Figura 27.B), 
comparado a enzima livre. A temperatura de $50{ }^{\circ} \mathrm{C}$ foi determinada como a melhor para manutenção da estabilidade acima de 48 horas de incubação, com atividade residual aproximadamente $17 \%$ maior que a atividade observada a $40{ }^{\circ} \mathrm{C}$. Nas temperaturas $60^{\circ} \mathrm{C}$ e $70^{\circ} \mathrm{C}$ (Figura 27. C e D) os derivados foram inativados mais rapidamente.
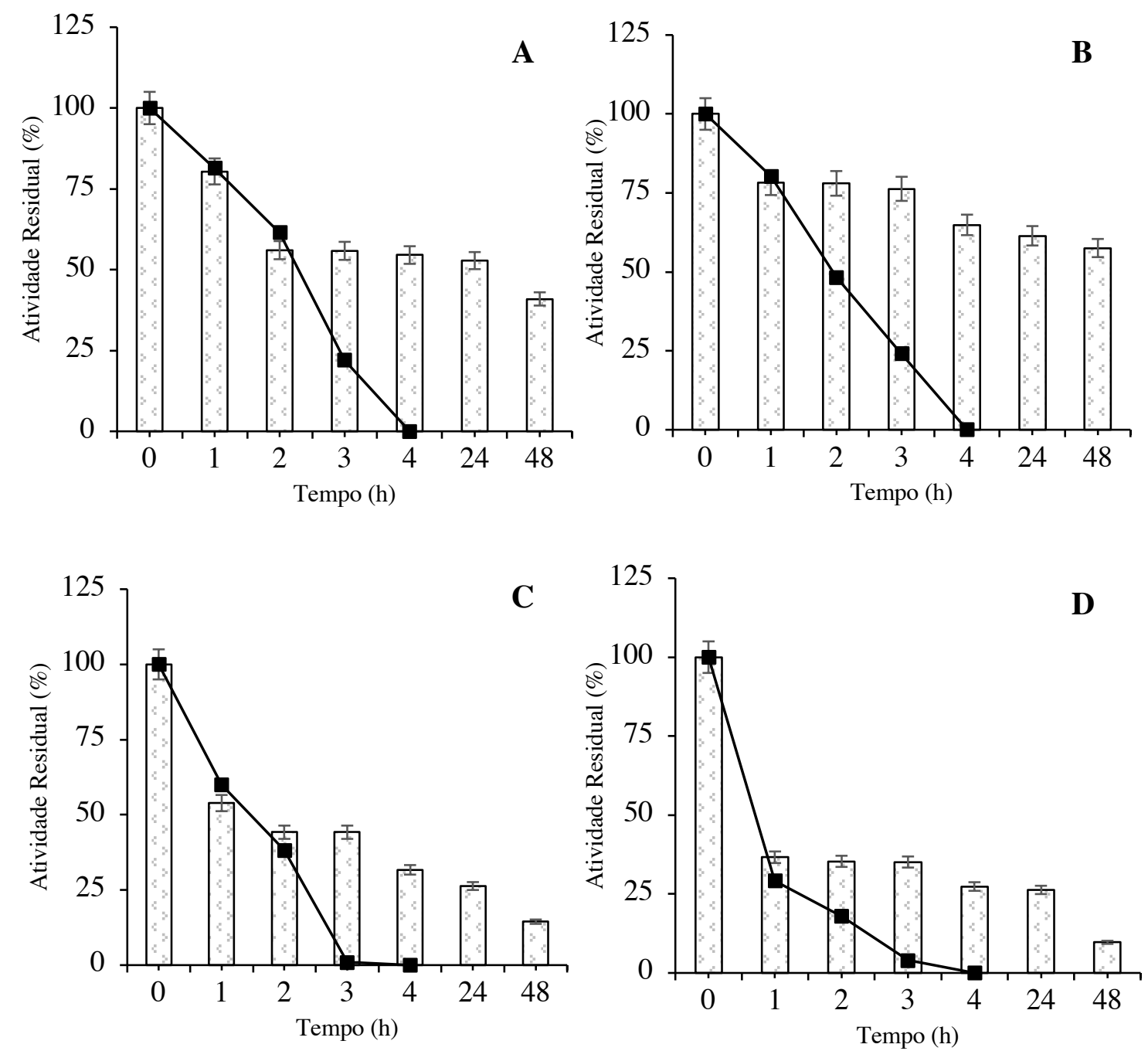

Figura 27. Estabilidade térmica dos derivados de $S$. thermophilum em Sepabeads C-18. Para tal, $40 \mathrm{mg}$ de derivados foram suspensos em $2 \mathrm{~mL}$ de tampão McIlvaine $\mathrm{pH}$ 6,0 e incubados em diferentes temperaturas. Para comparação $1 \mathrm{~mL}$ de extrato bruto foram adicionados a $1 \mathrm{ml}$ de tampão Mcllvaine pH 6,0 e incubados em diferentes temperaturas. (A) $40{ }^{\circ} \mathrm{C}$; (B) $50{ }^{\circ} \mathrm{C}$; (C) 60 ${ }^{\circ} \mathrm{C}$ e (D) $70^{\circ} \mathrm{C}$. Valores de atividade para cada período foram expressos em atividade relativa em relação à atividade dos derivados no tempo inicial do experimento. $\mathrm{O}$ resultado obtido para temperatura de $80^{\circ} \mathrm{C}$ foram omitidos, por apresentar resultados semelhantes a temperatura de 70 ${ }^{\circ} \mathrm{C}$. Legenda: ( $\mid$ ) derivado e ( $\left.\mathbf{a}\right)$ enzima livre.

Para o derivado em Duolite (Figura 28) identificou-se melhor estabilidade nas temperaturas de $40{ }^{\circ} \mathrm{C}$ (Figura 28. A) e $50{ }^{\circ} \mathrm{C}$ (Figura 28. B). Nessas temperaturas a t 50 
não foi atingida no período estudado. Com 48 horas de incubação, a $50{ }^{\circ} \mathrm{C}$, o derivado apresentou $13 \%$ mais atividade do que quando incubado a $40{ }^{\circ} \mathrm{C}$ pelo mesmo período. Nas temperaturas $60^{\circ} \mathrm{C}$ e $70^{\circ} \mathrm{C}$ (Figura 28. C e D) os derivados foram inativados mais rapidamente.
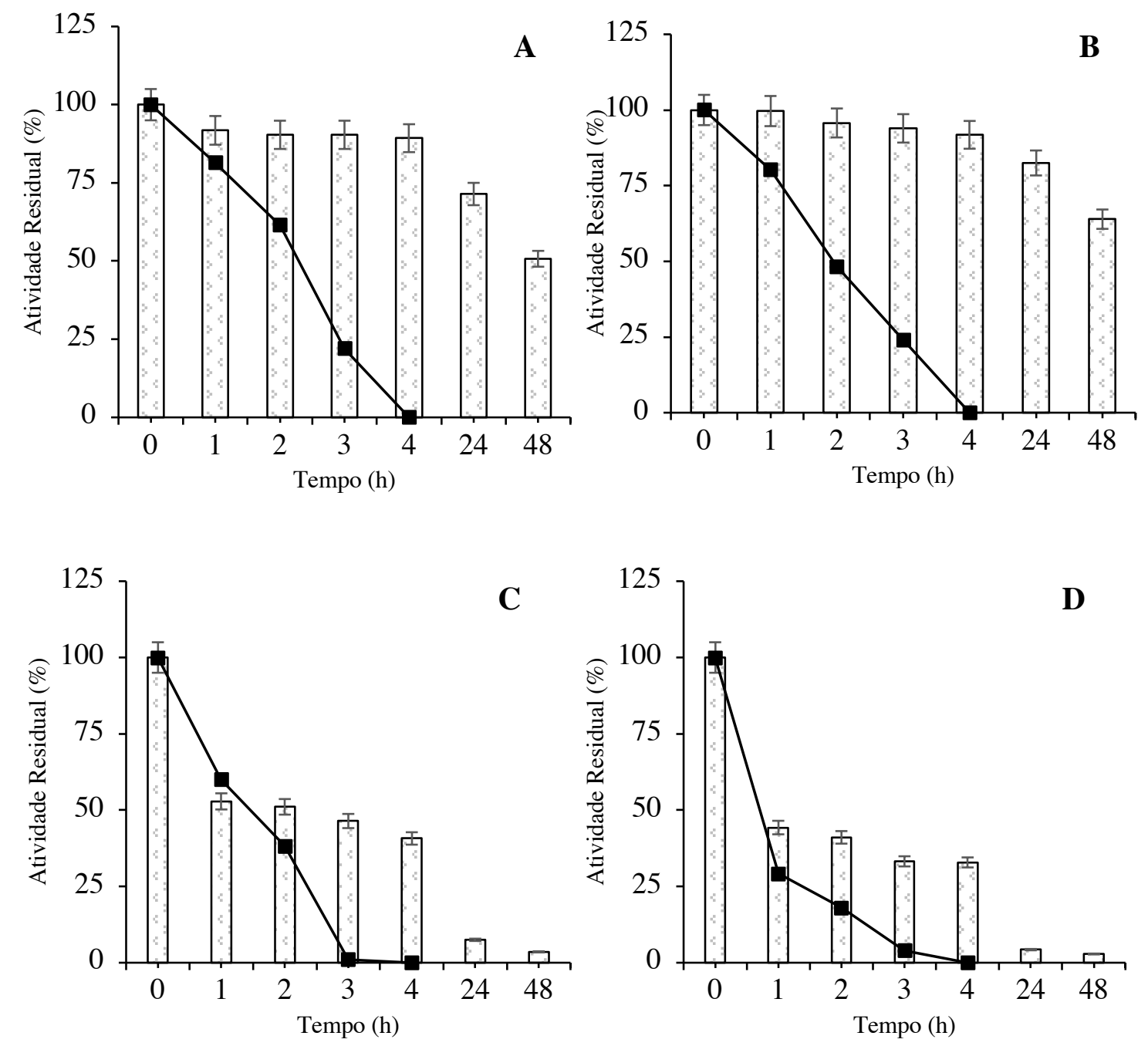

Figura 28. Estabilidade térmica dos derivados de $\boldsymbol{S}$. thermophilum em Duolite. Para tal, 40 $\mathrm{mg}$ de derivados foram suspensos em $2 \mathrm{~mL}$ de tampão McIlvaine $\mathrm{pH}$ 6,0 e incubados em diferentes temperaturas. Para comparação $1 \mathrm{~mL}$ de extrato bruto foram adicionados a $1 \mathrm{ml}$ de tampão McIlvaine pH 6,0 e incubados em diferentes temperaturas. (A) $40{ }^{\circ} \mathrm{C}$; (B) $50{ }^{\circ} \mathrm{C}$; (C) 60 ${ }^{\circ} \mathrm{C}$ e (D) $70^{\circ} \mathrm{C}$. Valores de atividade para cada período foram expressos em atividade relativa em relação à atividade dos derivados no tempo inicial do experimento. O resultado obtido para temperatura de $80^{\circ} \mathrm{C}$ foram omitidos, por apresentar resultados semelhantes a temperatura de 70 ${ }^{\circ} \mathrm{C}$. Legenda: ( $\mid$ ) derivado e ( $\left.\mathbf{\square}\right)$ enzima livre.

Para todos os suportes (Figuras 26, 27 e 28), registrou-se maior termoinativação a 70 e $80{ }^{\circ} \mathrm{C}$. A $70{ }^{\circ} \mathrm{C}$ todos os derivados mantiveram apenas $10-20 \%$ da atividade inicial com 48 horas de incubação. Em $80{ }^{\circ} \mathrm{C}$ (dados não mostrados) o derivado foi 
completamente inativado com 48 horas de incubação.

Observando os resultados obtidos na Tabela 11, é possível identificar os resultados de estabilidade de acordo com o parâmetro t50 $_{50}$ em minutos. A enzima livre possui boa estabilidade, a $40^{\circ} \mathrm{C}$ por até 140 minutos. A $50^{\circ} \mathrm{C}$ sua estabilidade é mantida com $50 \%$ da atividade residual, por até 110 minutos. Nas temperaturas $60^{\circ} \mathrm{C}$ e $70^{\circ} \mathrm{C}$, a estabilidade decresce em 50 e 10 minutos, respectivamente.

Tabela 11. Valores de $t_{50}$ em minutos dos derivados de $S$. thermophilum em diferentes temperaturas. Esses valores foram determinados em suspensão de $40 \mathrm{mg}$ de derivado em $2 \mathrm{~mL}$ de tampão McIlvaine pH 6,0 e 1 mL de extrato bruto em 1 mL de tampão McIlvaine pH 6,0.

\begin{tabular}{ccccc}
\hline \multirow{2}{*}{ Suportes } & \multicolumn{4}{c}{ Parâmetro t50 (min) } \\
\cline { 2 - 5 } & $40^{\circ} \mathrm{C}$ & $50^{\circ} \mathrm{C}$ & $60^{\circ} \mathrm{C}$ & $70^{\circ} \mathrm{C}$ \\
\hline Octyl- sepharose & $24 \mathrm{~h}^{*}$ & 150 & 30 & 10 \\
Sepabeads C-18 & $24 \mathrm{~h}^{*}$ & $>48 \mathrm{~h}^{*}$ & 90 & 30 \\
Duolite & $>48 \mathrm{~h}^{*}$ & $>48 \mathrm{~h}^{*}$ & 150 & 30 \\
Enzima Livre & 150 & 90 & 60 & 10 \\
\hline
\end{tabular}

* h: horas

Sinal de maior $(>)$ indica a impossibilidade de determinar com exatidão visto à limitação dos períodos avaliados.

Conclui-se que para a lipase de $S$. thermophilum, a imobilização no suporte hidrofóbico e de interação iônica Duolite proporcionou um aumento significativo na estabilidade térmica. Em adição, o derivado apresentou maior estabilidade térmica a $50^{\circ} \mathrm{C}$.

\subsubsection{Estabilidade em $\mathrm{pH}$ dos derivados nos suportes selecionados}

Da mesma forma que o estudo de estabilidade térmica dos derivados, observouse uma melhora da estabilidade ao $\mathrm{pH}$ da lipase de $S$. thermophilum imobilizada nos suportes analisados em relação a enzima livre. Os valores de $\mathrm{pH}$ analisados para os derivados foram: $6,7,8$ e 9; por até 48 horas de incubação, a $40^{\circ} \mathrm{C}$.

O derivado em Octyl (Figura 29) proporcionou um aumento na estabilidade em pH 6 (Figura 29.A), 7 (Figura 29. B) e 8 (Figura 29. C) em relação a enzima livre. Destacando a alta estabilidade desse derivado em $\mathrm{pH} 7$, onde manteve-se aproximadamente $58 \%$ de atividade residual, por 24 horas de incubação. Em 48 horas de 
incubação houve uma queda de 13\% da atividade residual. Em pH 9 (Figura 29. D) a t50 foi atingida em menos de 1 hora.
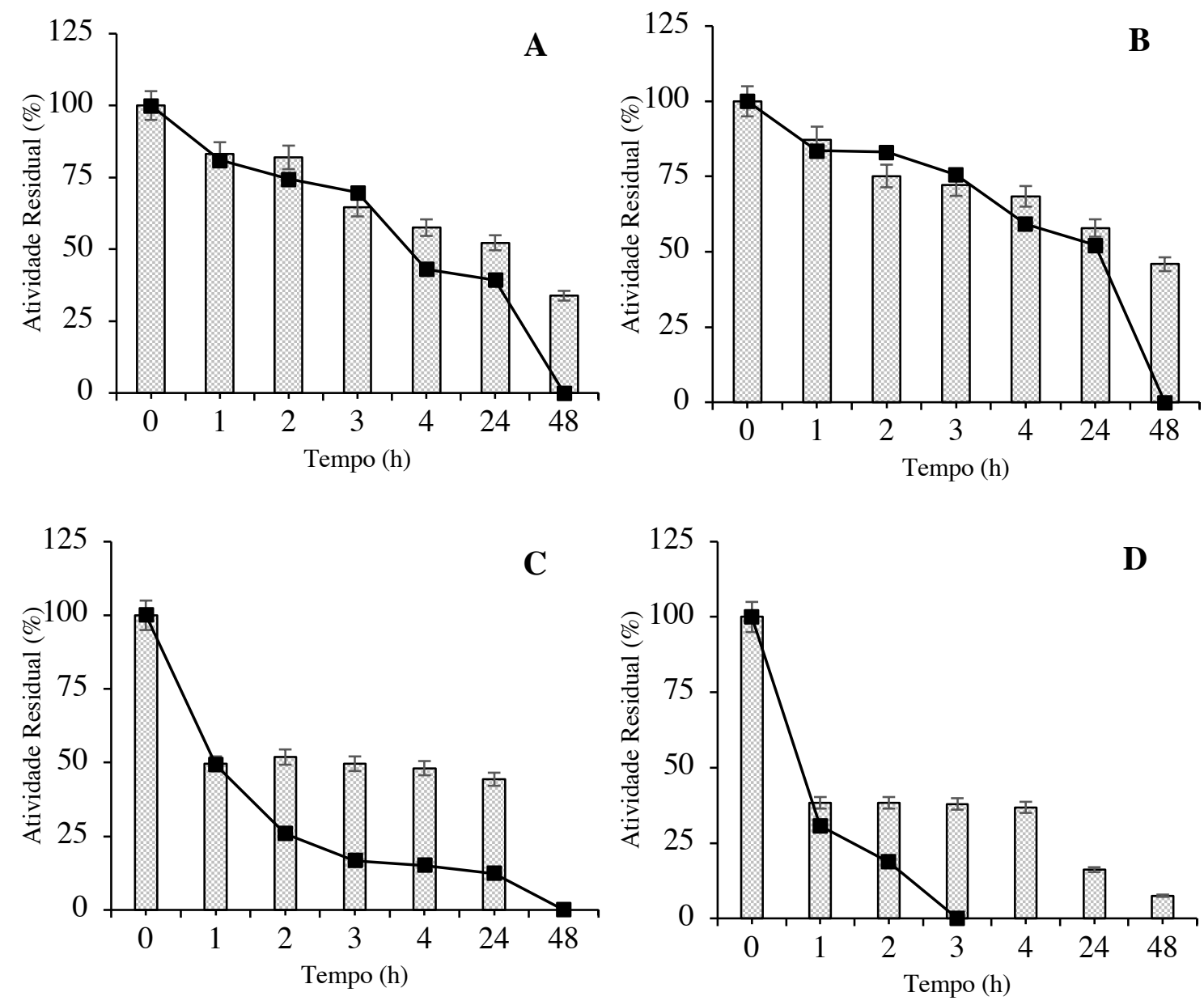

Figura 29. Estabilidade em pH dos derivados de $S$. thermophilum em Octyl-sepharose. Para tal, $40 \mathrm{mg}$ de derivados foram suspensos em $2 \mathrm{~mL}$ de tampão McIlvaine (A) $\mathrm{pH}$ 6; (B) $\mathrm{pH} 7 \mathrm{e}$ (C) $\mathrm{pH} 8$ e em (D) tampão glicina $\mathrm{pH}$ 9, incubados a $40^{\circ} \mathrm{C}$. Os resultados foram expressos em atividade relativa calculada em relação à atividade dos derivados no tempo inicial do experimento. Legenda: (| | ) derivado e ( $\mathbf{\square})$ livre.

O derivado de Sepabeads (Figura 30), também se mostrou mais estável ao pH que a enzima livre. Em pH 6 (Figura 30. A) o derivado manteve cerca de 60\% de atividade com 24 horas de incubação. Em pH 7 (Figura 30. B) a estabilidade do derivado foi semelhante ao da enzima livre, exceto na última amostra, com $48 \mathrm{~h}$ de incubação, onde o derivado manteve cerca de $50 \%$ da atividade inicial enquanto que a enzima livre estava completamente inativa. O derivado em pH 8 (Figura 30. C) atingiu a t $t_{50}$ entre após as 3 horas de incubação, sendo melhor que a enzima livre. Finalmente, em pH 9 atingiu a $t_{50}$ antes de 1 hora (Figura 30. D). 

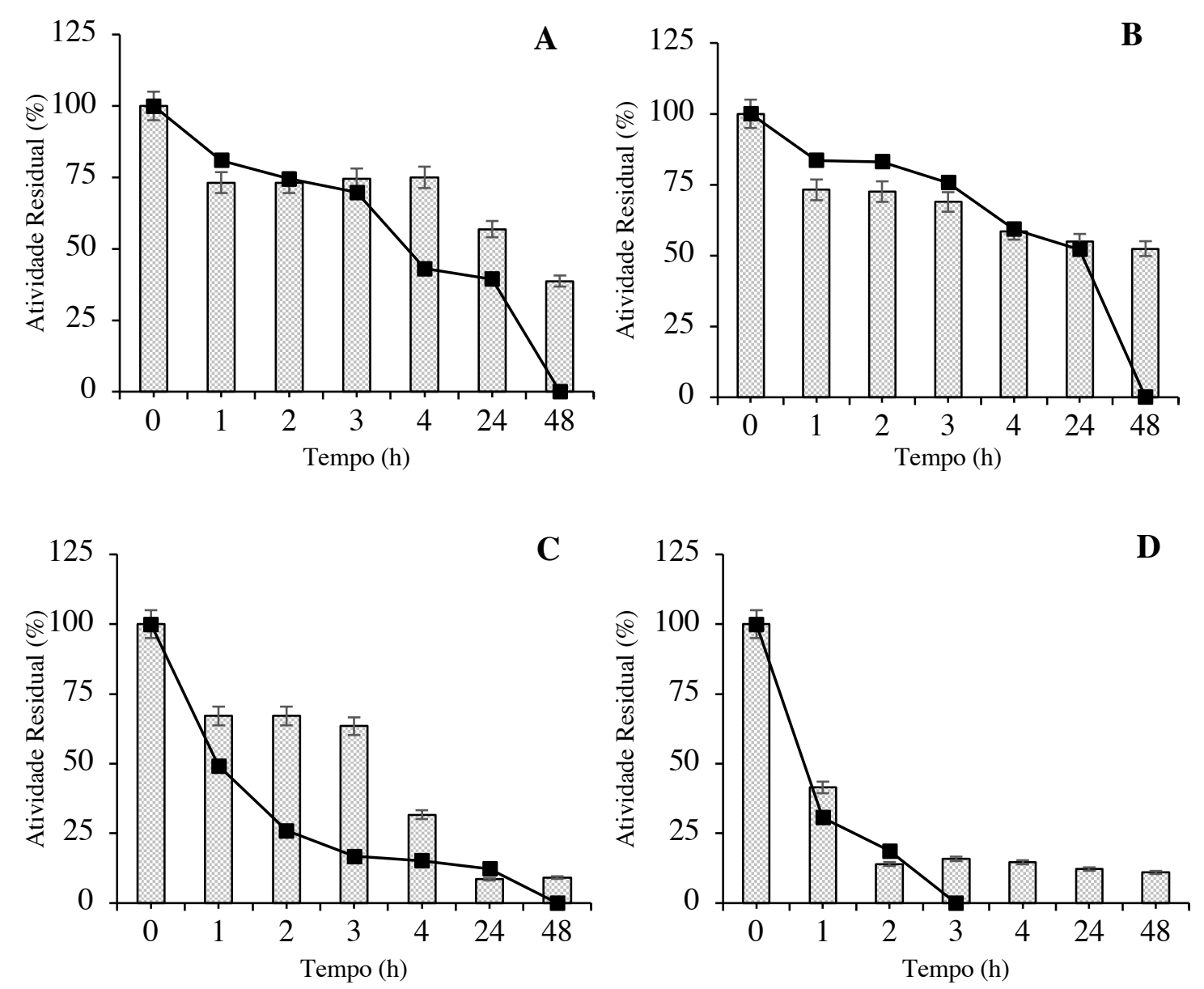

Figura 30. Estabilidade em pH dos derivados de $S$. thermophilum em Sepabeads C-18. Para tal, $40 \mathrm{mg}$ de derivados foram suspensos em $2 \mathrm{~mL}$ de tampão McIlvaine (A) pH 6; (B) pH 7 e (C) pH 8 e em (D) tampão glicina $\mathrm{pH}$ 9, incubados a $40^{\circ} \mathrm{C}$. Os resultados foram expressos em atividade relativa calculada em relação à atividade dos derivados no tempo inicial do experimento. Legenda: (|l) derivado e (a) livre.

Por fim, o derivado em Duolite (Figura 31) apresentou alta estabilidade em pH 6 (Figura 31. A) e 7 (Figura 31. B), com atividade residual acima de 50\% da atividade inicial por 48 horas de incubação. Entretanto, em pH 8 (Figura 31. C) e 9 (Figura 31. D) a t50 é atingida entre 3-4 horas e 2-3 horas de incubação, respectivamente. Em todos os pHs testados o derivado de Duolite foi mais estável que a enzima livre pelo menos em um ponto de amostragem. Foi observado que em $\mathrm{pH}$ inferior a 6 a lipase de $S$. thermophilum é dessorvida da matriz de Duolite (dados não mostrados). 

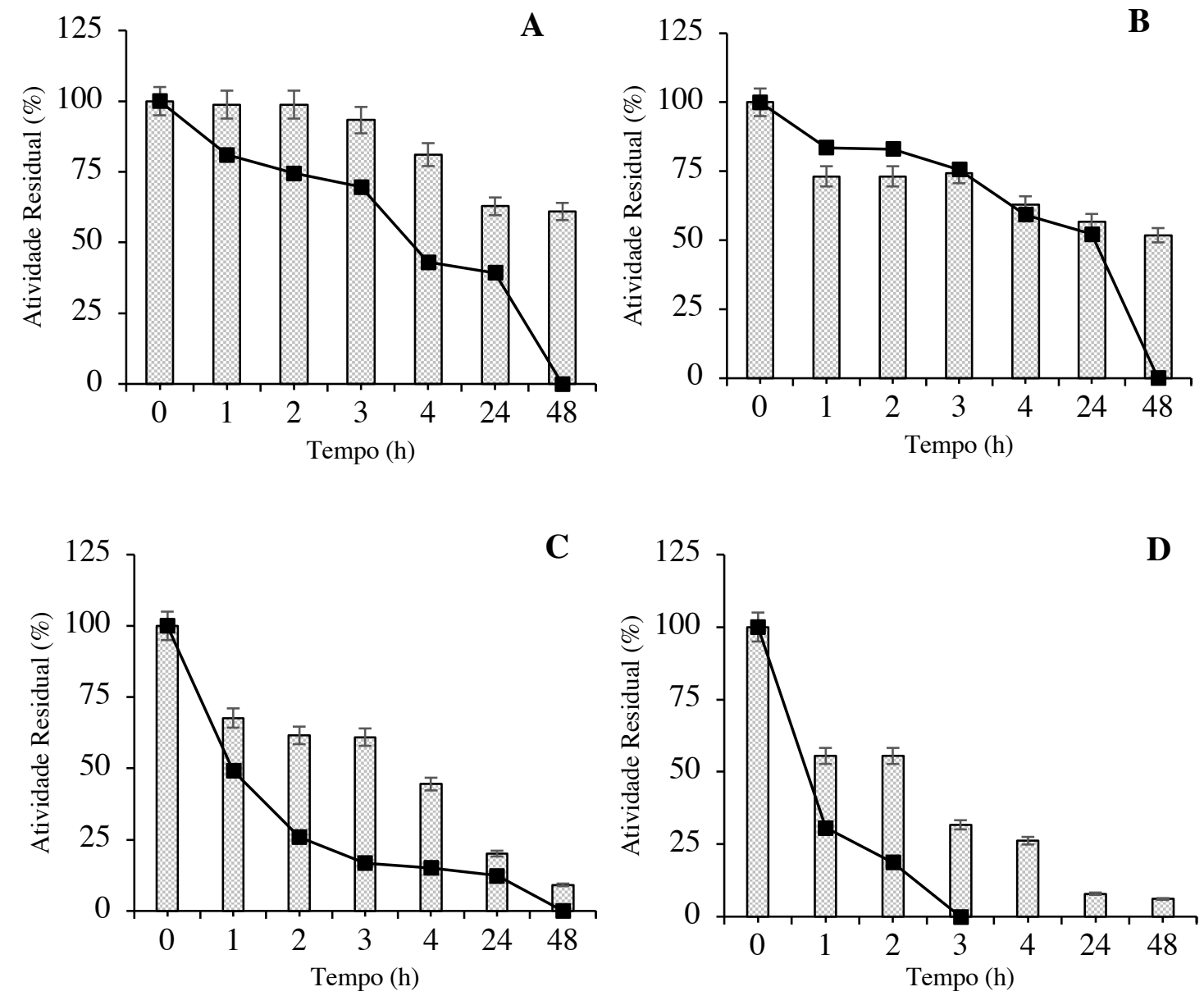

Figura 31. Estabilidade em pH dos derivados de $S$. thermophilum em Duolite. Para tal, $40 \mathrm{mg}$ de derivados foram suspensos em $2 \mathrm{~mL}$ de tampão Mcllvaine (A) $\mathrm{pH}$ 6; (B) $\mathrm{pH} 7 \mathrm{e}$ (C) $\mathrm{pH} 8 \mathrm{e}$ em (D) tampão glicina $\mathrm{pH}$ 9, incubados a $40^{\circ} \mathrm{C}$. Os resultados foram expressos em atividade relativa calculada em relação à atividade dos derivados no tempo inicial do experimento. Legenda: (| |) derivado e (匹) livre.

Na Tabela 12, é possível identificar os resultados de estabilidade de acordo com o parâmetro t ${ }_{50}$ expressa em minutos. Destacando a baixa estabilidade dos derivados e da enzima livre em $\mathrm{pH} 8$ e 9.

Em conclusão, os suportes que melhoram a estabilidade da lipase de $s$. thermophilum em pH 6 e 7 foram: Sepabeads C-18 e Duolite, apresentando atividade residual acima de $50 \%$ por 24 horas. 
Tabela 12. Valores de $t_{50}$ em minutos dos derivados de $S$. thermophilum em diferentes pH. Esses valores foram determinados em solução de $40 \mathrm{mg}$ de derivado em $2 \mathrm{~mL}$ de tampão mantido a $40^{\circ} \mathrm{C}$.

\begin{tabular}{ccccc}
\hline \multirow{2}{*}{ Suportes } & \multicolumn{4}{c}{ Parâmetro t $_{\mathbf{5 0}}(\mathbf{m i n})$} \\
\cline { 2 - 5 } & $\mathrm{pH} 6$ & $\mathrm{pH}$ & $\mathrm{pH} 8$ & $\mathrm{pH} 9$ \\
Octyl- sepharose & $24 \mathrm{~h}^{*}$ & $24-48 \mathrm{~h}^{*}$ & 150 & 30 \\
Sepabeads C-18 & $24-48 \mathrm{~h}^{*}$ & $>48 \mathrm{~h}^{*}$ & $3-4 \mathrm{~h}^{*}$ & 50 \\
Duolite & $>48 \mathrm{~h}^{*}$ & $>48 * \mathrm{~h}$ & $3-4 \mathrm{~h}^{*}$ & 150 \\
Enzima Livre & $3-4 \mathrm{~h}^{*}$ & $24 \mathrm{~h}^{*}$ & 60 & 30 \\
\hline
\end{tabular}

* h: horas

Sinal de maior $(>)$ indica a impossibilidade de determinar com exatidão visto à limitação dos períodos avaliados.

De acordo com os resultados obtidos a imobilização da proteína em suportes insolúveis de fato auxiliou na estabilização da estrutura da enzima, reduzindo a inativação do biocatalisador, seja térmica ou através do efeito de diferentes pHs. Com base nisso, a escolha do método mais adequado de imobilização deve ser feita de maneira criteriosa, avaliando as principais variáveis que irão influenciar a atividade da enzima para a reação de catálise em função do objetivo almejado (MENDES et al., 2010; SOUZA et al., 2017). A imobilização da enzima em suportes hidrofóbicos comumente promove mudanças conformacionais na região da "tampa", o que pode levar ao efeito de hiperativação (PÉREZ; ROCHA et al., 2018).

A estabilidade térmica é um parâmetro importante na viabilidade de uso de enzimas para aplicação industrial. Diferentes forças fracas atuam conjuntamente na estabilidade das proteínas e o equilíbrio das condições físico-químicas é descrita como elemento crucial para manutenção da estrutura nativa, de tal modo que a partir de uma dada temperatura, o desenovelamento proteico é abrupto. Portanto (NELSON; COX, 2014; MORONI et al., 2015; SCHON et al., 2017).

Em relação as variações no $\mathrm{pH}$ de um meio onde as proteínas estão inseridas, as diferentes conformações de uma proteína expõem distintas cadeias laterais de alguns resíduos de aminoácidos. Logo, a proteína pode adquirir ou perder prótons provocando alterações nas cargas e, portanto, nas interações que as regem. Em adição, a imobilização 
altera as interações e cargas da cadeia principal de aminoácidos da enzima, o que pode resultar em aumento da resistência a mudanças iônicas do meio (PÉREZ; ROCHA et al., 2018).

Sem a imobilização, a lipase obtida do fungo Aspergillus niger, estudada por Mhetras et al. (2009) apresentou estabilidade a $40^{\circ} \mathrm{C}$ por 3 horas, perdendo $52 \%$ da sua estabilidade após aumento da temperatura.

As lipases estudadas por Fernadez-Lafuente et al. (1998) e Cunha et al. (2009) apresentaram maior estabilidade quando imobilizadas em suportes sólidos, realizando a comparação com os valores de atividade do extrato bruto obtido. Em adição, Cunha et al. (2009) demonstrou o aumento da estabilidade em 50\% e aumento de $60 \%-95 \%$ da atividade enzimática da lipase de Penicillium simplicissimum, quando imobilizadas em suportes Octyl e Butyl, avaliadas a 40 e $50{ }^{\circ} \mathrm{C}$.

Diferentes lipases, mesmo quando imobilizadas no mesmo tipo de suporte, podem apresentar seletividade diferentes, como mostram os resultados de etanólise descritos por Moreno-Perez et al. (2014). Palomo et al. (2002) relataram a preservação da atividade enzimática de Candida antarctica a $100 \%$ por 200 horas de incubação, em pH 7, a $50{ }^{\circ} \mathrm{C}$, quando imobilizada em suporte Decaoctil. Em adição, Palomo et al. (2004) apresentaram a termoestabilidade da lipase de Bacillus themocatenulatus de 100\% em suporte Decaoctil por 48 horas, em $\mathrm{pH} 7$, a $65^{\circ} \mathrm{C}$.

Segundo a literatura, o suporte Octyl-Sepharose imobiliza a região da "tampa" da lipase estabilizando sua conformação aberta e expondo o sítio catalítico da enzima (MANOEL et al., 2015). Os estudos de SOUZA et al. (2017) demonstraram um efeito semelhante de imobilização de lipase de Moniliella spathulata. A imobilização em suportes iônicos reduziu significativamente a termoestabilidade. Por outro lado, os autores observaram que Octyl-sepharose causou ganho em estabilidade além de hiperativação, a qual pode ser explicada devido ao comportamento das lipases em suportes hidrofóbicos. Essa imobilização estabiliza a conformação aberta da enzima, facilitando a hidrólise do substrato (MATEO et al., 2007).

De acordo com o estudo de Vici (2015), para a lipase de Beauveria brongniartii os derivados mais estáveis foram BbLA-Duolite, seguido do BbLA-Octyl a 40 e $50{ }^{\circ} \mathrm{C}$. Em relação ao $\mathrm{pH}$, o derivado BbLA-Duolite obteve maior faixa de estabilidade ao ser 
analisado em uma faixa ampla de $\mathrm{pH}$.

Sendo assim, para as lipases produzidas por A. phoenicis, o suporte Octyl (retenção 98,83\%) proporcionou melhor estabilidade na temperatura de $50{ }^{\circ} \mathrm{C}$ e $\mathrm{pH} 6$, levando a uma hiperativação enzimática. Os suportes Sepabeads (retenção 76,55\%) e Duolite (retenção 76,55\%) apresentaram melhor estabilidade em pH 6, a $50{ }^{\circ} \mathrm{C}$ e $40{ }^{\circ} \mathrm{C}$, respectivamente. Para as lipases de S. thermophilum os suportes Sepabeads (retenção 98,59\%) e Duolite (retenção 98,73\%) proporcionaram maior estabilidade térmica a $40{ }^{\circ} \mathrm{C}$ e $50{ }^{\circ} \mathrm{C}$. E os suportes Octyl (retenção 96,99\%) e Duolite apresentaram maior estabilidade em pH 6 e 7.

Por conseguinte, estes derivados foram selecionados para testar sua estabilidade a solventes orgânicos para posterior aplicação na produção de biodiesel e hidrólise de óleos vegetais.

\subsubsection{Estabilidade em solventes dos derivados nos suportes selecionados}

Para completar as reações das aplicações biotecnológicas alvo deste trabalho, foi necessário a utilização de solventes para a condução e síntese dos produtos alvos.

Na reação de transesterificação são utilizados os solventes: ciclohexano, hexano, metanol, etanol e acetona. Para a reação de hidrólise é necessário a utilização de ciclohexano ou hexano. Desta maneira, a estabilidade destes derivados nos solventes é de grande importância para a condução destas reações, que normalmente ocorrem por 24 horas. As enzimas tendem a formar agregados em solventes orgânicos, na sua forma livre, na presença de solventes orgânicos, dificultado o acesso do substrato ao sítio ativo. A imobilização auxilia na atividade da lipase em solventes orgânicos, podendo chegar a valores 100 vezes mais altos (BRADY; JORDAAN, 2009).

Para as enzimas livres de $A$. phoenicis e $S$. thermophilum, em todos os solventes testados, a atividade residual foi inferior a $50 \%$, em tempo menor ou igual a 5 horas de experimento (dados não mostrados).

Analisando a Figura 32 para os derivados de $A$. phoenicis (Figura 32. A) observase que o suporte Octyl melhor proporcionou estabilidade nos solventes: ciclohexano e hexano; nos demais solventes a estabilidade neste suporte diminuiu aproximadamente $80 \%$, em 24 horas. O derivado de Duolite foi $60 \%$ e 51\% estável ciclohexano e hexano, 
respectivamente. Nos demais solventes reteve menos de $20 \%$ de atividade residual. Por fim, o derivado de Sepabeads teve menos de 50\% de atividade residual em todos os solventes testados, mantendo $48 \%$ e $46 \%$ de atividade nos solventes ciclohexano e hexano, respectivamente.

Para os derivados de $S$. thermophilum (Figura 32. B) observam-se diferentes perfis de estabilidade em comparação a lipase de A. phoenicis. O derivado de Duolite manteve atividade residual acima de $70 \%$ em todos os solventes testados, em 24 horas de experimento. Em adição, o derivado de Sepabeads apresentou estabilidade satisfatória em todos os solventes testados, com atividade residual acima de $51 \%$ em etanol e acima de $65 \%$ nos demais solventes. Por outro lado, o derivado de Octyl apresentou atividade residual acima de $50 \%$ apenas para o solvente ciclohexano
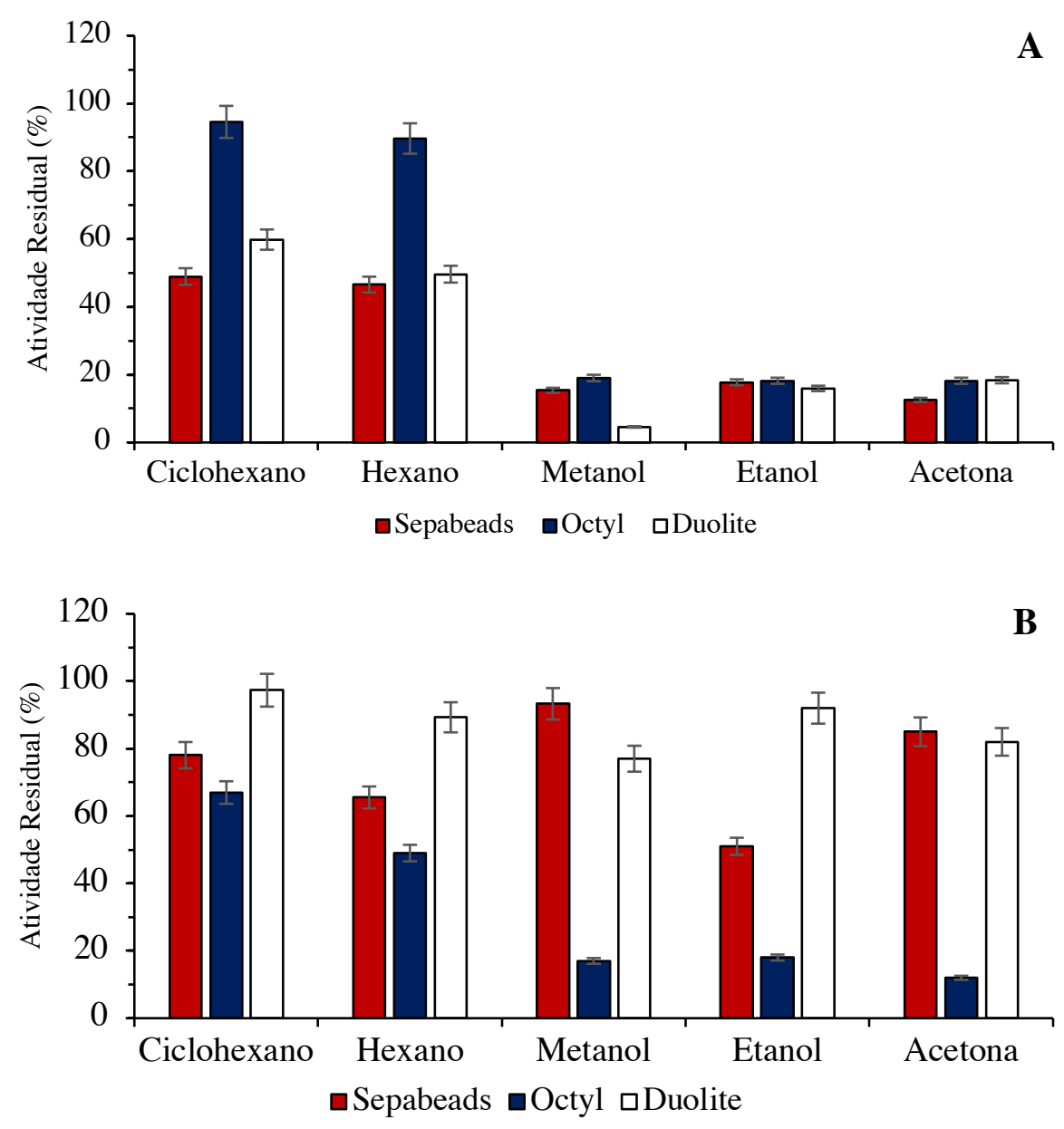

Figura 32. Estabilidade dos derivados em diferentes solventes em 24 horas. As atividades enzimáticas foram avaliadas para os derivados da (A) lipase de A. phoenicis e (B) lipase de $S$. thermophilum. $40 \mathrm{mg}$ de derivado foram diluídos em $1 \mathrm{~mL}$ de tampão Mcllvaine e $1 \mathrm{~mL}$ de solvente orgânico. Uma solução com adição de tampão McIlvaine, excluindo o solvente, foi utilizada como controle. As amostras foram mantidas em temperatura ambiente por 24 horas. 


\section{PARTE IV - Aplicação}

Biotecnológica: produção

de biodiesel através de

transesterificação

enzimática 


\subsubsection{Reação de transesterificação utilizando o substrato sintético pNPP}

Este experimento foi utilizado como um método de screening das lipases dos fungos A. phoenicis e S. thermophilum imobilizadas em Octyl, Duolite e Sepabeads, visando verificar a viabilidade dos derivados para a reação de transesterificação. O ensaio de quantificação foi realizado com etanol, a $40{ }^{\circ} \mathrm{C}$.

Através dos dados obtidos na Tabela 13, é possível observar que a lipase do fungo S. thermophilum imobilizada em Duolite e Sepabeads C-18 apresentam melhor atividade de transesterificação. Em contrapartida, as lipases de A. phoenicis imobilizadas em Octyl, Duolite e Sepabeads apresentaram atividade de transesterificação muito baixas comparadas com os resultados obtidos para as lipases imobilizadas de S. thermophilum.

Tabela 13. Screening de transesterificação utilizando o substrato sintético pNPP Valores de atividade enzimática (U/g) após análise colorimétrica da transesterificação com etanol a $40{ }^{\circ} \mathrm{C}$, das lipases produzidas pelos fungos $A$. phoenicis e $S$. thermophilum imobilizadas nos suportes selecionados.

\begin{tabular}{cccc}
\hline \multirow{2}{*}{ Fungos } & \multicolumn{3}{c}{ Atividade enzimática (U/g) } \\
\cline { 2 - 4 } & Duolite & Sepabeads C-18 & Octyl-sepharose \\
\hline S. thermophilum & 10,5 & 6,77 & 0,256 \\
A. phoenicis & 1,5 & 0,100 & 0,111 \\
\hline
\end{tabular}

O potencial para a produção de biodiesel deve ser avaliado em suportes como Sepabeads C-18 ou Duolite, pois suportes a base de agarose como Octyl-sepharose podem sofrer degradação na presença dos solventes utilizados nessas reações. (VICI, 2015).

Em conclusão, as lipases produzidas pelo fungo $S$. thermophilum imobilizadas em Duolite e Sepabeads apresentaram maior capacidade de transesterificação, quando comparadas as lipases de A. phoenicis. Portanto, estes foram selecionados para prosseguimento dos experimentos de transesterificação (Figura 33). 


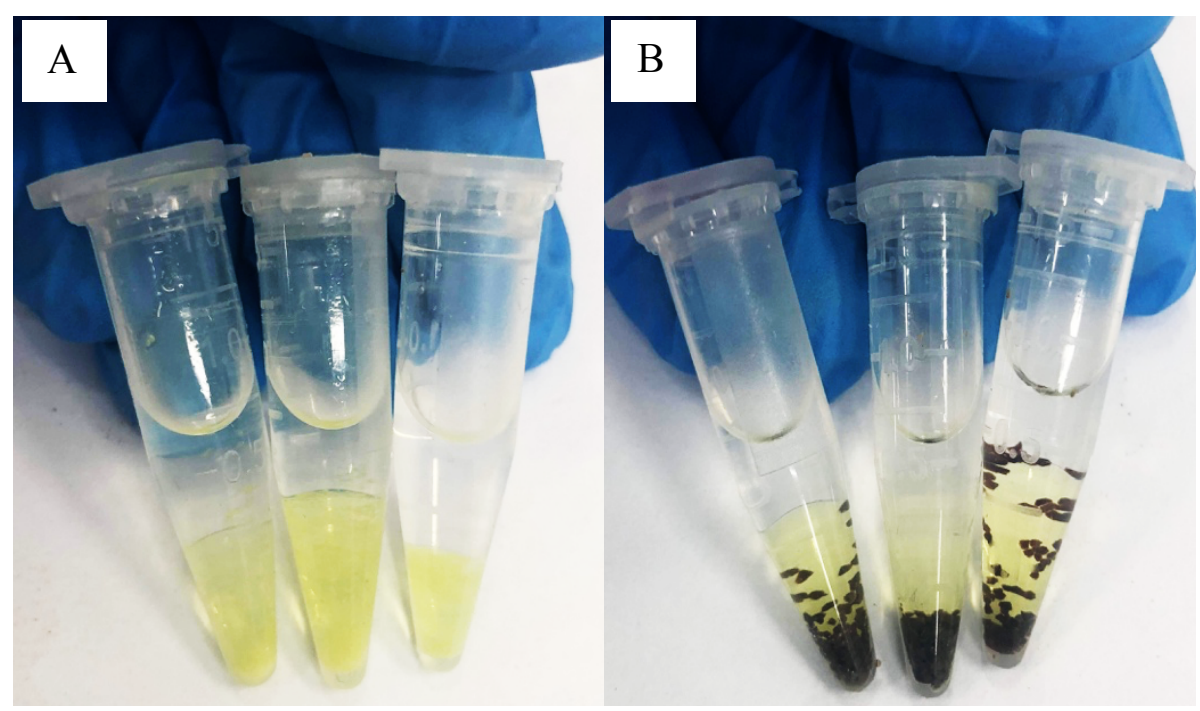

Figura 33. Ensaio de quantificação colorimétrica de transesterificação. Lipases produzidas pelo fungo S. thermophilum imobilizadas nos suportes (A) Sepabeads C-18 e (B) Duolite, após 1 hora de reação a $40{ }^{\circ} \mathrm{C}$ com etanol, com adição de $\mathrm{NaOH}$ na proporção $1: 1$ para interrupção da reação de transesterificação do pNPP.

\subsubsection{Otimização da utilização do derivado para a reação de transesterificação}

Para os derivados em Duolite e Sepabeads C-18 de S. thermophilum - que serão denominados, respectivamente, St-Duolite e St-Sepabeads a partir de agora no texto selecionados anteriormente, foi avaliado a faixa de temperatura de reação de $30{ }^{\circ} \mathrm{C}$ a 60 ${ }^{\circ} \mathrm{C}$ com a finalidade de identificar a melhor condição para atividade do derivado na reação de transesterificação. Para isto foi conduzida a reação de transesterificação com pNPP, utilizando os metanol e etanol, por 1 hora, em diferentes temperaturas.

Através da análise dos resultados (Figura 34), a melhor temperatura para StDuolite e St-Sepabeads foi $50{ }^{\circ} \mathrm{C}$, onde St-Duolite (Figura 34. A) apresentou atividade de $11 \mathrm{U} / \mathrm{g}$ em etanol e 12,4 U/g em metanol. Para St-Sepabeads (Figura 34. B) a atividade foi de 7,2 U/g em etanol e 8,6 U/g em metanol nesta mesma temperatura. O rendimento para a utilização de metanol foi de aproximadamente 1,2\% melhor que etanol. Em adição, St-Duolite apresentou atividade enzimática 0,8 a 1,5\% melhor que St-Sepabeads.

Em estudos publicados por Santi et al. (2018); Soares (2015) e Neto et al. (2000), foi constatado que o metanol proporciona maior rendimento para as reações de transesterificações. Entretanto, o etanol proporcionou boa influência na atividade enzimática na reação.

Apesar da reação com etanol ser um pouco menos eficiente que quando o metanol 
é usado, sua utilização é mais interessante pois, possui ótima vantagem ambiental, já que faz parte da matriz energética considerada renovável. Já o metanol possui origem fóssil, além de alta toxicidade, apresentando uma escala maior de risco à saúde em comparação ao etanol. Enquanto o etanol em exposição prolongada é capaz de ocasionar danos à saúde, o metanol pode causar sérios danos a quem o manuseia mesmo que por tempos curtos. Ao substituir o metanol por etanol continua-se com as mesmas medidas de segurança para manuseio, porém a substituição significa menos riscos para o processo, para os funcionários e para o meio ambiente (POTRICH et al., 2018).
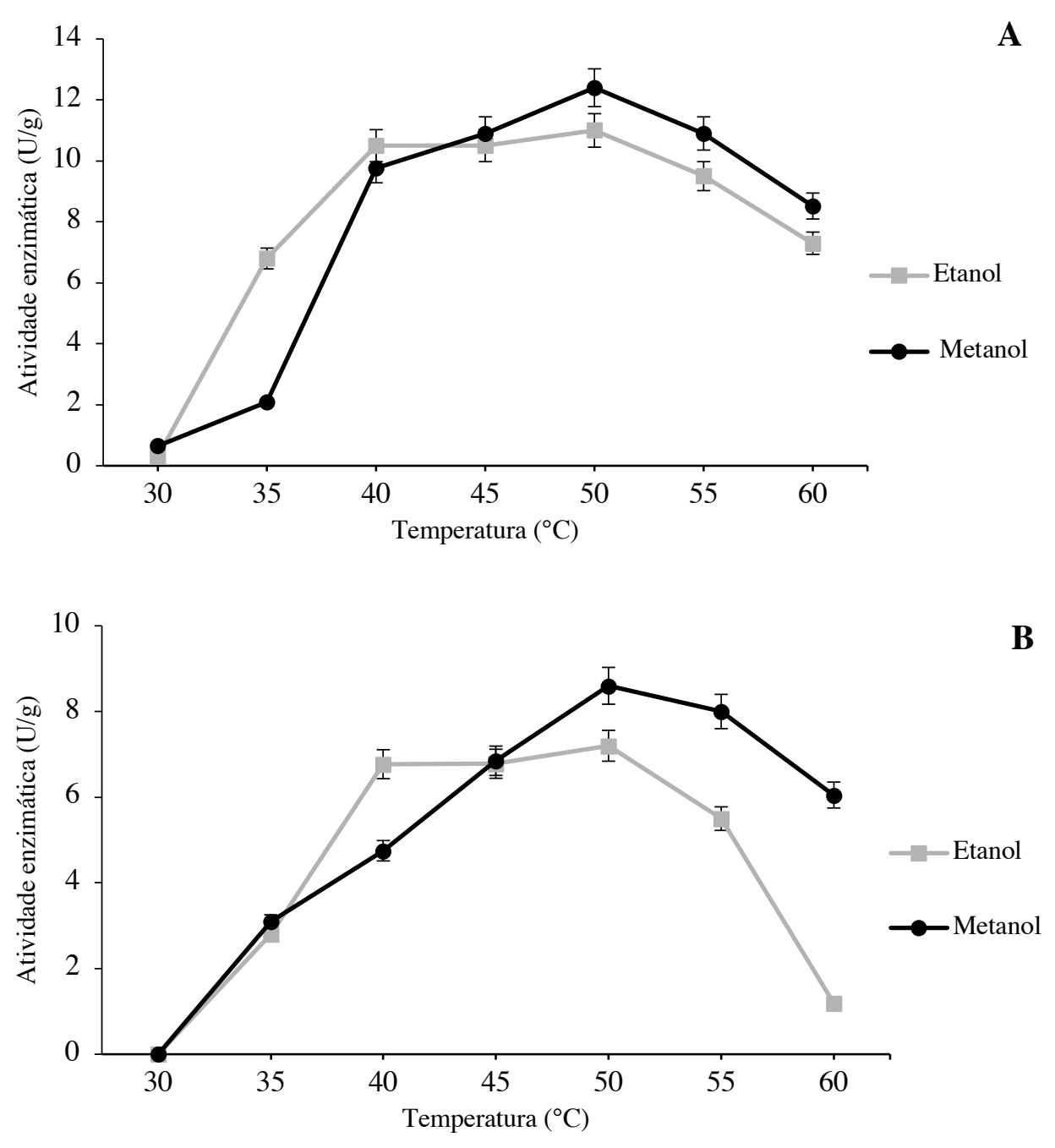

Figura 34. Ensaio de transesterificação de pNPP pelos derivados selecionados em diferentes temperaturas e álcoois. A atividade enzimática de transesterificação foi avaliada para (A) StDuolite e (B) St-Sepabeads. A reação foi conduzida utilizando metanol e etanol na faixa de temperatura de $30^{\circ} \mathrm{C}$ a $60{ }^{\circ} \mathrm{C}$. 


\subsubsection{Reação de transesterificação enzimática para a produção de biodiesel}

\subsubsection{Screening entre St-Duolite e St-Sepabeads para a reação de transesterificação de óleos vegetais}

A reação de transesterificação enzimática foi conduzida em meio não aquoso. Foram utilizados os derivados St-Sepabeads e St-Duolite. Inicialmente, a reação foi realizada com uma razão molar de metanol:óleo de soja (1:2), para um volume final de $2,5 \mathrm{~mL}, 82 \%$ de ciclohexano e $12 \%$ (m/v óleo) de derivado seco em acetona, a $50{ }^{\circ} \mathrm{C}$, com agitação orbital de 140 rpm por 24 horas.

As amostras foram analisadas por CG, em parceira com o Prof. Dr. Anizio Marcio de Faria e Andressa Tironi Vieira, no laboratório de Pesquisas em Materiais de Separação e Cromatografia Química no Instituto de Ciências Exatas e Naturais do Pontal, Universidade Federal de Uberlândia, Ituiutaba, MG - Brasil.

A partir dos dados obtidos (Figura 35), o St-Duolite (Figura 35. 1) apresentou resultado bastante satisfatório, obtendo-se concentração total de ésteres metílicos de 20,8\%. Em comparação, para o St-Sepabeads (Figura 35. 2), obteve-se concentração total de ésteres metílicos de 7,1\%, resultando em uma diferença de aproximadamente $14 \%$ entre os suportes analisados. Em relação a composição dos ésteres metílicos, as amostras apresentaram teores de aproximadamente $80 \%$ de oleato de metila (C18:1) (Tabela 14).

Com base nesse resultado, o derivado St-Duolite foi selecionado para os próximos experimentos. Dando seguimento ao estudo, a reação de transesterificação foi conduzida utilizando etanol e diferentes óleos vegetais como substratos. 

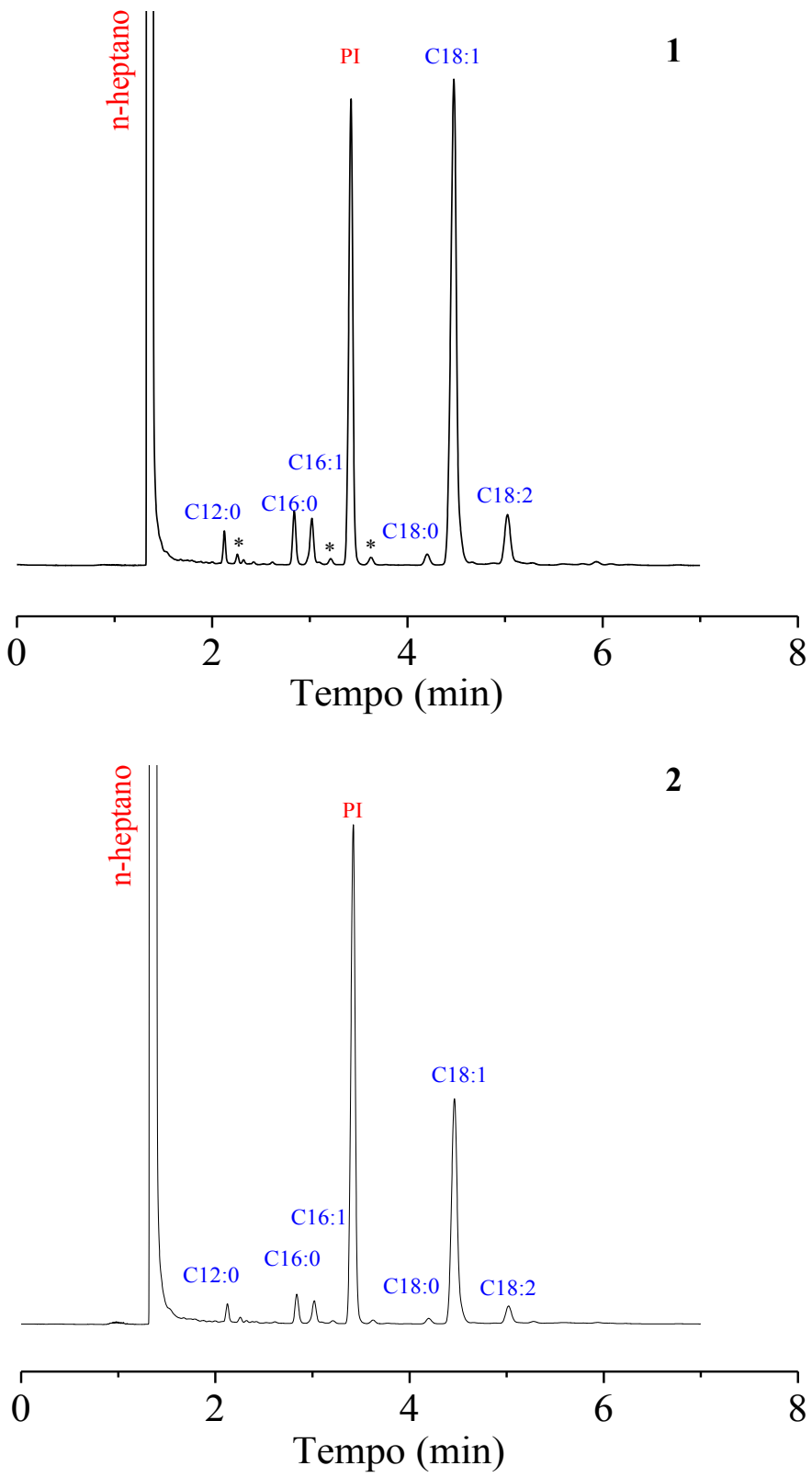

Figura 35. Cromatogramas das amostras para qualificação e quantificação de ésteres metílicos. (1) St-Duolite e (2) St-Sepabeads. A reação foi realizada com uma razão molar de metanol:óleo de soja (1:2), para um volume final de $2,5 \mathrm{~mL}, 82 \%$ de ciclohexano e $12 \%(\mathrm{~m} / \mathrm{v}$ óleo) de derivado seco em acetona em diferentes concentrações, a $50{ }^{\circ} \mathrm{C}$, com agitação orbital de $140 \mathrm{rpm}$ por 24 horas. 
Tabela 14. Identificação e quantificação de ésteres metílicos das amostras analisadas. Teor total de ésteres metílicos representado em porcentagem das amostras de reação conduzidas por derivados de A. phoenicis e S. thermophilum em Duolite e Sepabeads C-18.

\begin{tabular}{|c|c|c|c|c|c|c|c|c|}
\hline \multirow{2}{*}{ Amostras } & \multicolumn{7}{|c|}{ Composição relativa de ésteres (\%) } & \multirow{2}{*}{$\begin{array}{c}\text { Teor total de } \\
\text { ésteres } \\
\text { metílicos }^{1} \\
\text { (\%) }\end{array}$} \\
\hline & C12:0 & C16:0 & C16:1 & C18:0 & C18:1 & C18:2 & C18:3 & \\
\hline Controle & - & - & - & - & - & - & - & $\mathbf{0 , 0}$ \\
\hline S.t Duolite & 2,0 & 4,9 & 4,6 & 1,6 & 78,5 & 7,8 & 0,5 & 20,8 \\
\hline $\begin{array}{c}\text { S.t } \\
\text { Sepabeads }\end{array}$ & 3,2 & 6,2 & 5,7 & 0,2 & 78,7 & 6,1 & 0,0 & 7,1 \\
\hline
\end{tabular}

* S.t $=$ S. thermophilum

* $\mathbf{1}$ = teor total de ésteres na solução do padrão interno.

\subsubsection{Testes de diferentes metodologias para a reação de transesterificação enzimática}

A reação de transesterificação enzimática foi conduzida em meio não aquoso, utilizando o derivado St-Duolite. Os óleos vegetais testados para a transesterificação foram: açaí, buriti, castanha do Brasil e girassol. Em adição, a partir do estudo de Kourmentza et al. (2018), foi utilizado o material de descarte borra de café seco em estufa a $35{ }^{\circ} \mathrm{C}$, por 24 horas. A reação controle foi realizada com a adição do óleo correspondente e borra de café, sem a adição de derivado seco.

Foram abordados dois tipos de metodologias e ajustes diferentes para a condução das reações de transesterificação dos diferentes óleos a $50^{\circ} \mathrm{C}$, sendo elas:

(1) etanol:óleo vegetal (3:1) para um volume final de 2,061 mL +10\% (m/v óleo) do derivado seco, sem adição de ciclohexano (Tabela 15).

(2) etanol:óleo vegetal (1:2) para um volume final de 2,5 mL + 10\% (m/v óleo) do derivado seco e $82 \%$ de ciclohexano (Tabela 16).

Observando os resultados, verifica-se a melhor eficiência do método (2) em comparação ao método (1) em relação ao teor total de ésteres etílicos produzidos pelo derivado.

De acordo com a Tabela 15, para o método (1) o melhor resultado foi de 6,22\% 
de teor total de ésteres etílicos produzidos ao ser utilizado o óleo buriti. Em sequência, o resultado para a transesterificação com óleo de açaí foi a produção de 3,18\% de ésteres etílicos. Em relação a composição relativa de ésteres, a reação com o óleo de buriti e a borra de café apresentaram altas concentrações de oleato de etila, com 92,2\% e 82,6\% respectivamente.

Tabela 15. Identificação e quantificação de ésteres etílicos nas amostras após reação de transesterificação com diferentes óleos vegetais. A reação foi realizada utilizando o método (1) = etanol:óleo vegetal $(3: 1)+10 \%$ (m/v óleo) derivado, sem adição de ciclohexano.

\begin{tabular}{ccccccc}
\hline \multirow{2}{*}{\begin{tabular}{c} 
Amostras \\
\cline { 2 - 6 }
\end{tabular}} & C16:0 & $\mathbf{C 1 8 : 0}$ & $\mathbf{C 1 8 : 1}$ & $\mathbf{C 1 8 : 2}$ & $\mathbf{C 1 8 : 3}$ & $\begin{array}{c}\text { Ceor total de } \\
\text { ésteres etílicos } \\
(\%)\end{array}$ \\
\hline Soja & - & - & - & - & - & ND \\
Buriti & 7,8 & - & 92,2 & - & - & $\mathbf{6 , 2 2}$ \\
Açaí & 11,3 & 4,7 & 72,3 & 11,7 & - & $\mathbf{3 , 1 8}$ \\
Castanha do Brasil & 16,2 & - & 71,0 & 12,7 & - & $\mathbf{1 , 3 1}$ \\
Girassol & 26,8 & 7,1 & 43,3 & 22,7 & - & $\mathbf{1 , 7 9}$ \\
Borra de Café & 17,4 & - & 82,6 & - & - & $\mathbf{1 , 0 3}$ \\
\hline
\end{tabular}

$\mathbf{1}=$ teor total de ésteres na solução do padrão interno.

Para a metodologia (2) (Tabela 16), a reação de transesterificação com óleo de girassol resultou em 53,78\% de teor de ésteres etílicos, seguido da reação com óleo de buriti resultando em 33,92\% e óleo de soja 30,91\%. Os cromatogramas obtidos para estes óleos estão representados na Figura 36. Em relação a composição relativa de ésteres, todos os óleos testados seguindo esta metodologia apresentaram maiores concentrações de oleato de etila, seguido linoleato de etila. Isto se deve a concentração de ácidos oleicos e linoleicos presentes nos óleos e borra de café, utilizados como substratos. Ao fim da reação, os derivados foram lavados com ciclohexano e armazenados em refrigerador a $4^{\circ} \mathrm{C}$.

Portanto, a metodologia (2) foi definida como a melhor para produção de biodiesel a partir de óleo girassol, utilizando o derivado Duolite. Esta metodologia foi adotada 
como padrão para produção de biodiesel para posteriores análises do produto final.

Tabela 16. Identificação e quantificação de ésteres etílicos nas amostras após reação de transesterificação com diferentes óleos vegetais. A reação foi realizada utilizando o método (2) $=$ etanol:óleo vegetal $(1: 2)+10 \%(\mathrm{~m} / \mathrm{v}$ óleo) derivado e $82 \%$ de ciclohexano.

\begin{tabular}{|c|c|c|c|c|c|c|}
\hline \multirow{2}{*}{ Amostras } & \multicolumn{5}{|c|}{ Composição relativa de ésteres (\%) } & \multirow{2}{*}{$\begin{array}{c}\text { Teor total de } \\
\text { ésteres } \\
\text { etílicos }^{1} \\
(\%)\end{array}$} \\
\hline & C16:0 & C18:0 & C18:1 & C18:2 & C18:3 & \\
\hline Soja & 6,2 & 1,7 & 83,5 & 8,7 & - & 30,91 \\
\hline Buriti & 5,8 & 1,8 & 81,9 & 10,4 & - & 33,92 \\
\hline Açaí & 12,5 & 5,5 & 69,3 & 12,7 & - & 5,16 \\
\hline $\begin{array}{c}\text { Castanha do } \\
\text { Brasil }\end{array}$ & 16,2 & 6,7 & 61,4 & 15,7 & - & 3,94 \\
\hline Girassol & 4,6 & 1,7 & 85,8 & 7,9 & - & 53,78 \\
\hline Borra de Café & 26,6 & 8,9 & 41,4 & 23,1 & - & 1,26 \\
\hline
\end{tabular}

$\mathbf{1}=$ teor total de ésteres na solução do padrão interno. 

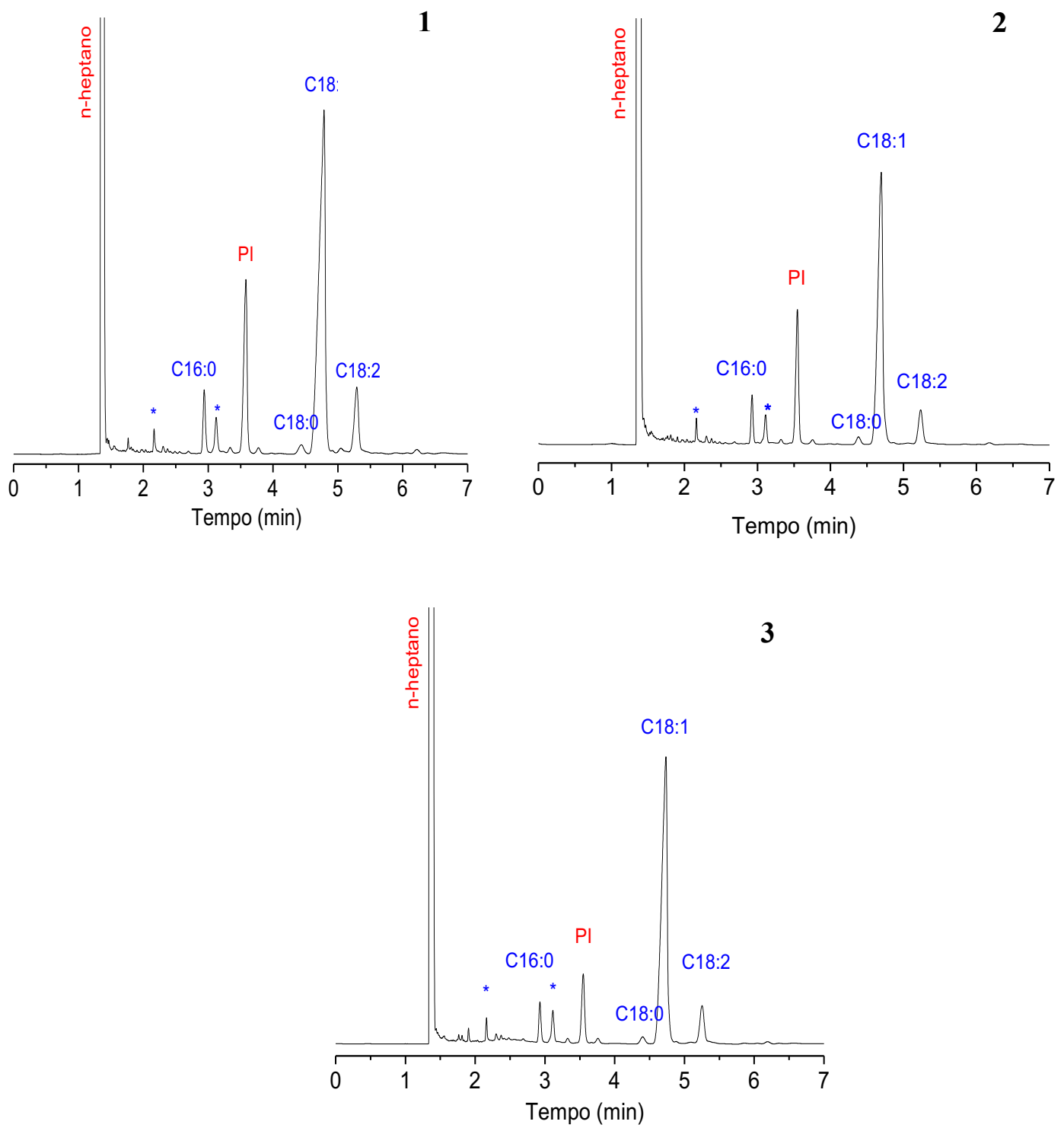

Figura 36. Cromatogramas das leituras das amostras em CG, para qualificação e quantificação de ésteres etílicos. A reação de transesterificação que resultou nos seguintes cromatogramas foi conduzida da seguinte maneira: etanol:óleo vegetal $(1: 2)+10 \%(\mathrm{~m} / \mathrm{v}$ óleo $)$ de derivado de St-Duolite seco e $82 \%$ de ciclohexano. Os cromatogramas representam o resultado para os seguintes óleos: (1) óleo de buriti (2) óleo de soja e (3) óleo de girassol.

$\mathrm{Na}$ bibliografia encontra-se o estudo onde a utilização da lipase comercial de Mucor miehei (Lipozyme TM IM60) para a reação de transesterificação de gordura bovina, utilizando etanol, hexano e 12,5 a $25 \%$ de enzima, por 5 horas, resultou no valor de $94.5 \%$ total ésteres (NELSON et al., 1996).

De acordo com Bakó-Bélafi et al. (2002) a lipase comercial Candida antarctica (Novozym 435) imobilizada em resina de Macroporos proporcionou conversão de 97\% do óleo de girassol ao ser adicionado metanol de forma contínua no sistema, que 
desfavorece a inibição do substrato na reação.

Nos estudos de Shah et al. (2004) a lipase de Candida rugosa e de Chromobacterium imobilizadas em suporte Celite foram submetidas a etanólise, com óleo de Jatropha em sistema de reacional livre de solventes, por 8 horas. Para derivado de Candida rugosa o total de ésteres etílicos obtidos foi de $1.0 \%$ e para o derivado de Chromobacterium o valor foi de 71\%. Em contrapartida, em estudo feito por Oznur et al. (2002), para a lipase de Candida antarctica, a reação de transesterificação com óleo de semente de algodão em sistema livre de solvente obteve o total de $92 \%$ ésteres.

A característica mais interessante da utilização de lipases para a reação de transesterificação é a habilidade da enzima em utilizar ácidos graxos livres, mono, di e triacilgliceróis como substratos para a reação (NELSON et al., 1996). Estudos do processo de transesterificação de óleos vegetais utilizando como catalisador a lipase, apontam alta seletividade e conversões de triglicerídeos e ácidos graxos livres à biodiesel. Desta maneira, o desenvolvimento da tecnologia da reação enzimática pode se tornar uma estratégia competitiva no mercado de combustíveis renováveis (KROUMOV et al., 2007).

\subsubsection{Análises físico-químicas do biodiesel produzido por transesterificação enzimática}

Foram analisados os parâmetros: índice de acidez, índice de iodo e rendimento do biodiesel produzido através da transesterificação enzimática do óleo de girassol.

O índice de acidez encontrado, seguindo a metodologia de Aricetti (2010), foi de $0,56 \mathrm{mg} \mathrm{NaOH} / \mathrm{g}$. O índice de iodo encontrado, seguindo a metodologia de Aricetti (2010), foi de 42,3 $\mathrm{g} \mathrm{I}_{2} / 100 \mathrm{~g}$ de amostra de biodiesel.

O cálculo de rendimento foi realizado de acordo com Oliveira et al. (2012). A massa de biodiesel foi pesada depois da reação de transesterificação enzimática em função da massa de óleo de girassol empregada na transesterificação. Para fins de cálculo, de acordo com Zambelli (2009) a densidade do óleo de girassol a $25{ }^{\circ} \mathrm{C}$ é $0,891 \mathrm{~g} / \mathrm{cm}^{3}$, portanto a massa utilizada de óleo de girassol, para a produção de biodiesel foi de 0,262 g. A massa de biodiesel obtida para 2,5 mL de reação foi de 0,194 g. Portanto, obteve-se $74 \%$ de rendimento para a reação de transesterificação enzimática do óleo de girassol, 
utilizando o derivado St-Duolite.

As características do biodiesel produzido nesse trabalho foram melhores do que as do biodiesel produzido no estuo de Garcia et al. (2015), que obtiveram um biodiesel com acidez de 0,70 $\mathrm{mg}$ de $\mathrm{NaOH} / \mathrm{g}$ de biodiesel e índice de iodo de 59,9g $\mathrm{I}_{2} / 100 \mathrm{~g}$ de amostra de biodiesel.

A legislação brasileira (ABNT NBR 14448) permite valor máximo de 0,50 mg de $\mathrm{NaOH} / \mathrm{g}$ para índice de acidez no biodiesel. No entanto, a norma de padronização americana de biodiesel ASTM D6751 permite valores máximos de 0,80 mg de NaOH/g. Apesar de não existir no Brasil um limite máximo ou mínimo para a concentração de iodo encontrado no biodiesel, a legislação europeia (EN14111) prevê que deve existir, no máximo, $120 \mathrm{~g} \mathrm{I}_{2} / 100 \mathrm{~g}$ de amostra (LOBO et al., 2009; GARCIA et al., 2015; ARAUJO, 2005).

Observando a literatura, no estudo de Shimada et al. (2002) avaliou-se a metanólise com lipase de Candida antarctica imobilizada em um suporte cerâmico SM10, onde alcançou um rendimento acima de $90 \%$ de biodiesel produzido. A transesterificação utilizando lipase de Thermomyces lanuginosus imobilizada em Immobead 150 propiciou um rendimento de síntese de biodiesel de 54\% num tempo de 3 horas (BORDINHÃO et al., 2014). Por fim, no estudo de Sangaletti (2012), a transesterificação utilizando lipase comercial Candida antarctica imobilizada em resina de acrílico (Novozym 425) resultou em um rendimento máximo de 85\%.

O biodiesel produzido no presente trabalho se adequa às normas estabelecidas internacionalmente que determinam a qualidade do biocombustível. Em adição, a partir do rendimento adquirido de $74 \%$, conclui-se que a utilização da lipase de S. thermophilum imobilizada em Duolite mostra-se promissora para uso industrialmente.

\subsubsection{Reciclagem do derivado para reação de transesterificação}

A partir da metodologia de análise colorimétrica da transesterificação utilizando etanol e pNPP, foi identificada o número de reusos do derivado St-Duolite por um período de 3 semanas. O derivado foi utilizado para promover a reação de transesterificação uma vez em cada semana, seguido da lavagem com ciclohexano, secagem em acetona e armazenamento a $4{ }^{\circ} \mathrm{C}$ (Figura 37). Os derivados testados foram primeiramente 
utilizados na reação de transesterificação com os óleos de soja, buriti, açaí, girassol e castanha do Brasil.

O derivado St-Duolite submetido à reação de produção de biodiesel, mantiveram uma atividade residual acima de 50\%, sem perdas significativas da atividade, por até 3 semanas. Demonstrando mais uma vantagem em utilizar a técnica de imobilização para promover a reação e sua versatilidade para uso industrial.

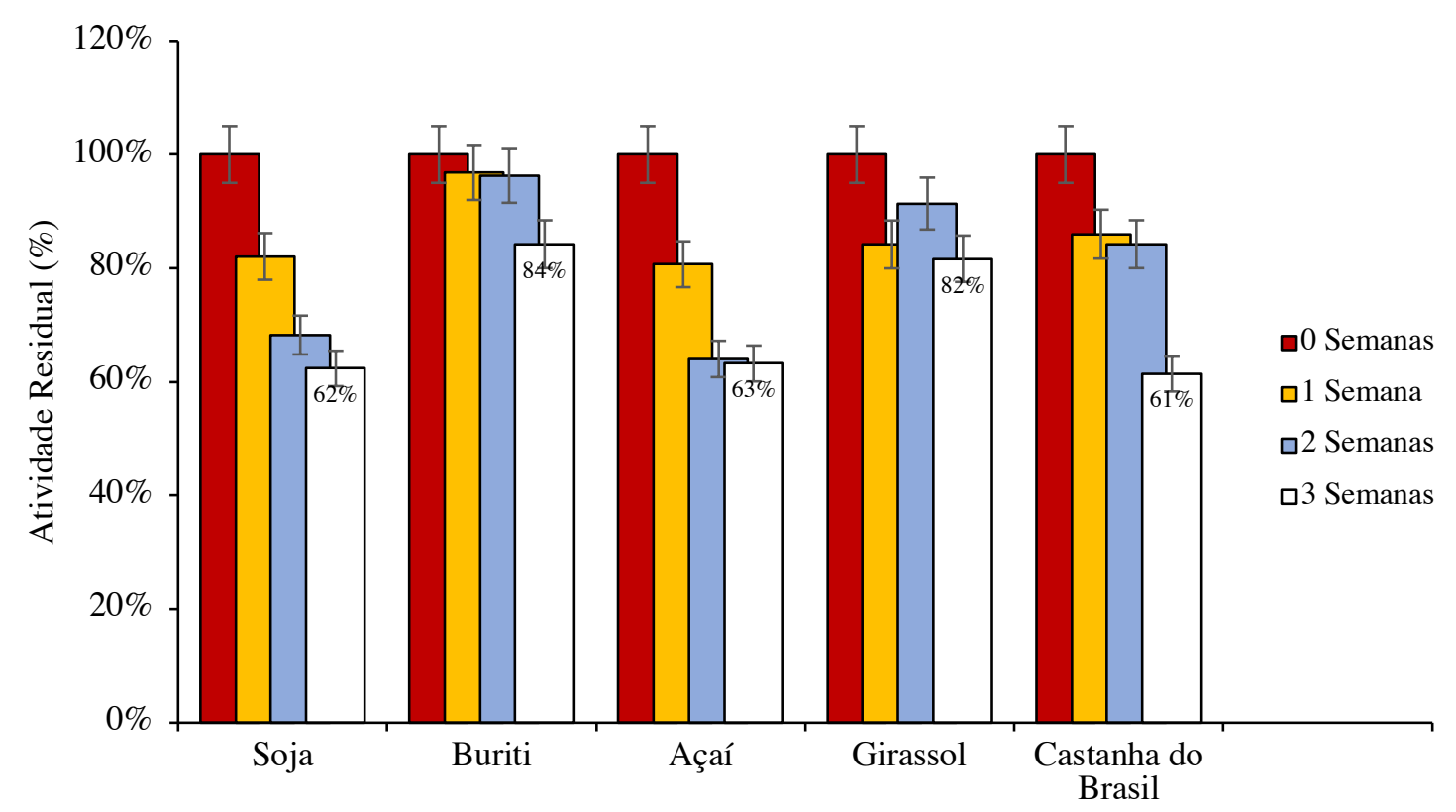

Figura 37. Reutilização do derivado St-Duolite utilizado na reação de transesterificação por 3 semanas.

Shimada et al. (1999) relatou taxa de conversão de ésteres de $95 \%$ até 50 ciclos de reutilização da lipase de Candida antarctica (Novozym 435) imobilizada, correspondendo a 100 dias de reutilização. Em adição, a manutenção da eficiência da enzima imobilizada está relacionada com o álcool utilizado na reação e também com o solvente que é utilizado para a lavagem dos derivados após a reação. A utilização de nhexano foi reportado como melhor opção para lavagem, auxiliando na manutenção da capacidade enzimática do derivado (RODRIGUES et al., 2008). 
PARTE V - Aplicação

Biotecnológica: hidrólise

\section{enzimática para obtenção}

de ácidos graxos totais 


\subsubsection{Otimização da utilização do derivado para a reação de hidrólise}

Para os experimentos de hidrólise foi selecionada a lipase produzida pelo fungo A. phoenicis cultivado em meio SR e $1 \%$ de óleo de girassol, subsequentemente imobilizada em suporte hidrofóbico Octyl-sepharose. O derivado obtido será denominado Ap-Octyl a partir desse momento no texto.

O derivado Ap-Octyl foi inicialmente caracterizado quanto a melhor temperatura e pH de reação de hidrólise de pNPP. Para isto, $10 \mathrm{mg}$ de derivado foi incubado a $50{ }^{\circ} \mathrm{C}$ em meio com faixa de $\mathrm{pH} 3$ a 10, com a finalidade de encontrar o $\mathrm{pH}$ do meio que melhor auxilia na atividade enzimática. Os resultados foram representados em U/mg de derivado.

Similarmente, para determinar a melhor temperatura de atividade, $10 \mathrm{mg}$ de derivado foi incubado em meio com tampão McIlvaine $\mathrm{pH} 6$ e em diferentes temperaturas - entre $30^{\circ} \mathrm{C}$ e $50^{\circ} \mathrm{C}$. Os resultados foram representados em $\mathrm{U} / \mathrm{mg}$ de derivado.

Ao observar o resultado obtido (Tabela 17), em pH 5 a atividade enzimática foi de $0,848 \mathrm{U} / \mathrm{mg}$. Em contrapartida, o melhor resultado de atividade enzimática foi em $\mathrm{pH}$ $6 \operatorname{com} 1,192 \mathrm{U} / \mathrm{mg}$.

Em relação a temperatura (Tabela 18), verifica-se melhor atividade enzimática a $50{ }^{\circ} \mathrm{C}$, em comparação com as demais temperaturas testadas. Desta maneira, foram atribuídos os seguintes parâmetros para a reação de hidrólise pelo derivado Ap-Octyl: 50 ${ }^{\circ} \mathrm{C}, \mathrm{pH} 6$.

Tabela 17. Avaliação do efeito do pH do meio reacional para a hidrólise de pNPP por ApOctyl. As amostras foram incubadas em temperatura de $50{ }^{\circ} \mathrm{C}$ em diferentes $\mathrm{pHs}$.

\begin{tabular}{cc}
\hline $\mathbf{p H}$ & Derivado em Octyl (U/mg) \\
\hline 3 & 0,554 \\
4 & 0,529 \\
5 & 0,848 \\
6 & 1,192 \\
7 & 0,681 \\
8 & 0,470 \\
9 & 0,194 \\
10 & 0,084 \\
\hline
\end{tabular}


Tabela 18. Avaliação do efeito da temperatura na reação de hidrólise de pNPP por ApOctyl. As amostras foram incubadas em pH 6, em diferentes temperaturas.

\begin{tabular}{cc}
\hline $\begin{array}{c}\text { Temperatura } \\
\left({ }^{\circ} \mathbf{C}\right)\end{array}$ & $\begin{array}{c}\text { Derivado em Octyl } \\
(\mathbf{U} / \mathbf{m g})\end{array}$ \\
\hline 30 & 0,503 \\
40 & 0,697 \\
50 & 1,183 \\
60 & 0,571 \\
70 & 0,401 \\
80 & 0,324 \\
\hline
\end{tabular}

$\mathrm{Na}$ literatura, a lipase imobilizada em suporte Octyl proporciona vantagem reacional por se ligar a região hidrofóbica da região da tampa da enzima, permitindo exposição do sítio ativo ao substrato. A imobilização da lipase em suporte Octylsepharose proporcionou aumento na atividade enzimática de diferentes microrganismos como: Humicola lanuginosa, Candida antarctica e Pseudomonas fluorescens (PÉREZ; ROCHA et al., 2018).

\subsubsection{Hidrólise dos óleos vegetais}

A hidrólise de óleos e gorduras tem a finalidade de produzir ácidos graxos livres, acilgliceróis parciais e glicerol. A reação de hidrólise foi conduzida com os seguintes óleos vegetais: soja (Glycine max (L.) Merr), buriti (Mauritia flexuosa), açaí (Euterpe oleracea), pracaxi (Pentaclethra Macroloba), ojon (Elaeis oleifera (Kunth)) e manteiga de tucumã (Astrocaryum aculeatum) submetidos a um sistema bifásico orgânico-aquoso, utilizando a lipase de $A$. phoenicis imobilizada em suporte Octyl-sepharose.

O processo de hidrólise enzimática necessita de dois requisitos para a operação: a formação de uma interface lipídeo/água e a absorção da enzima nesta interface. Assim, quanto maior a interface, maior será a quantidade de enzima adsorvida, acarretando velocidades de hidrólise mais elevadas. A reação foi realizada de acordo com Materiais e Métodos.

A concentração de ácidos graxos liberados em $\mathrm{mg} / \mathrm{mL}$ foi quantificada através do método colorimétrico sulfofosfo-vanilina (ANSCHAU et al., 2017; PÉREZ et al., 2018). De forma geral, esta metodologia inclui evaporação da amostra por solvente, adição de 
ácidos sulfúrico, observação do desenvolvimento de cor ao adicionar o reagente fosfovanilina e leitura de absorbância para mensuração da concentração de lipídios baseado em uma curva padrão (Figura 38).

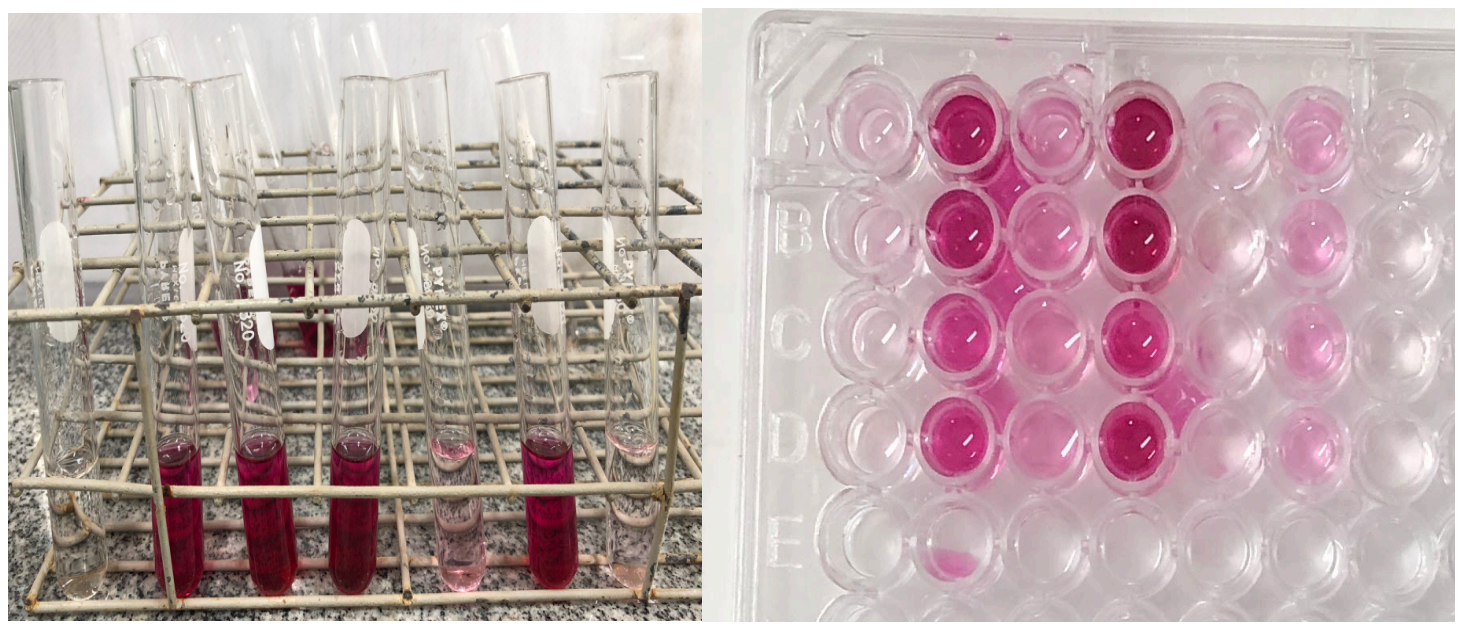

Figura 38. Amostras submetidas ao método colorimétrico sulfofosfo-vanilina para quantificação de ácidos graxos livres. $5 \mu \mathrm{L}$ de amostra retiradas após período determinado de hidrólise foram adicionados a 2,4 $\mathrm{ml}$ de reagente fosfo-vanilina. Em seguida, $200 \mu \mathrm{L}$ da solução resultante foram adicionados em placa de ELISA para leitura a $530 \mathrm{~nm}$ (ANSCHAU et al., 2017; PÉREZ et al., 2018).

Os resultados demonstraram (Figura 39) que para todos os óleos vegetais utilizados, houve maior concentração de ácidos graxos livres com 4 horas de reação de hidrólise. Para os óleos de soja, buriti, açaí e ojon houve um aumento na concentração de ácido graxo totais de $13 \%, 32 \%, 23 \%$ e $1 \%$ respectivamente, entre 3 e 4 horas de reação. Porém, para os mesmos óleos, houve queda de ácidos graxos livres de 25\%, 82\% 57\% e $45 \%$ entre 4 horas e 24 horas de reação.

Os óleos pracaxi e manteiga de tucumã apresentaram baixas concentrações de ácidos graxos livres, $0,932 \mathrm{mg} / \mathrm{mL}$ e $0,83 \mathrm{mg} / \mathrm{mL}$, respectivamente, em 4 horas de reação, comparando-se aos demais óleos vegetais utilizados. Entretanto, apresentaram igualmente uma queda na concentração de ácidos graxos em 24 horas de reação.

A partir destes resultados, concluiu-se que o derivado de $A$. phoenicis em Octylsepharose foi capaz de hidrolisar os óleos vegetais com eficiência, sendo os óleos de buriti $(3,4 \mathrm{mg} / \mathrm{mL})$, açaí $(3,06 \mathrm{mg} / \mathrm{mL})$ e ojon $(2,278 \mathrm{mg} / \mathrm{mL})$ os melhores substratos, resultando em altas concentrações de ácidos graxos livres. 


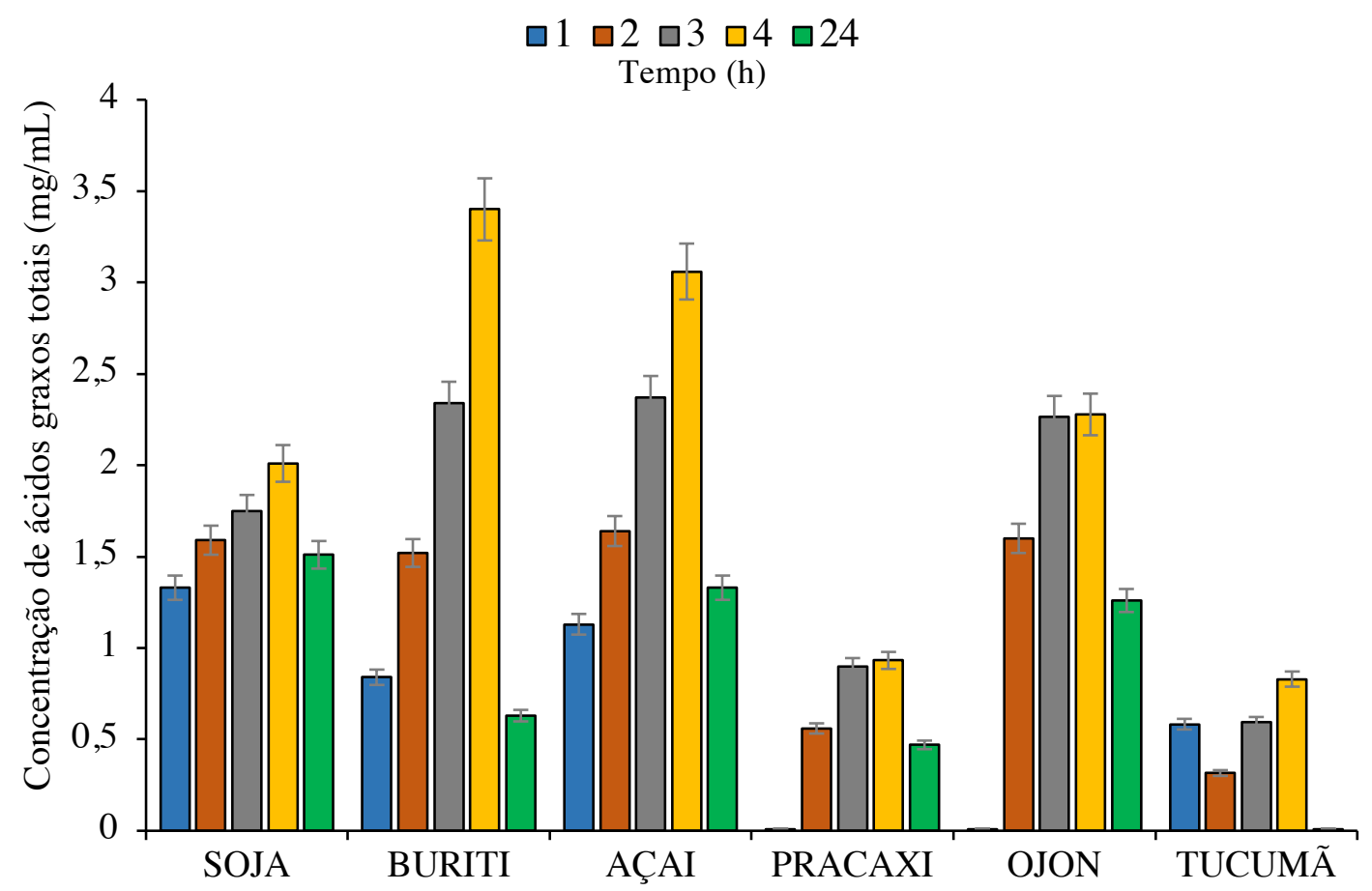

Figura 39. Concentração de ácidos graxos livres $(\mathrm{mg} / \mathrm{mL})$ obtidos após hidrólise de óleos vegetais pelo derivado Ap-Octyl. Quantificados através de alíquotas retiradas da reação de hidrólise nos períodos de 1 a 4 horas e 24 horas com os óleos (soja, buriti, açaí, pracaxi, ojon e manteiga de tucumã). Para a reação de hidrólise foram adicionados: $5 \mathrm{~mL}$ de tampão Tris-HCl $0,1 \mathrm{M}$ - pH 6,0; 4,5 mL de ciclohexano; $0,5 \mathrm{~mL}$ do óleo vegetal e $4 \%$ de derivado. A reação foi incubada a $50{ }^{\circ} \mathrm{C}$ com rotação a $120 \mathrm{rpm}$ por até 24 horas. A quantificação foi realizada através de método colorimétrico sulfofosfo-vanilina com leitura em espectrofotômetro a $530 \mathrm{~nm}$.

$\mathrm{Na}$ literatura encontra-se diferentes lipases de microrganismos utilizadas para a hidrólise de óleos para a produção de ácidos graxos. No estudo de Fu et al, (1995), foi relatado que lipases produzidas por Candida cylindracea utilizadas para hidrólise de sebo e óleo de linhaça são comercializadas em indústrias japonesas. Estas lipases são capazes de produzir 4000 toneladas de ácidos graxos por ano, para aplicações em diferentes setores industriais.

Lipases de Candida rugosa, Aspergillus niger e Rhizopus arrhizus foram utilizadas para promover a hidrólise em sistema de frascos agitados, dos óleos de coco e oliva, em 72 horas e obteve-se 97\% de hidrólise (LINFIELD et al. 1984). Nos estudos de Khor et al. (1986), a lipase produzida por Candida rugosa proporcionou melhores resultados de hidrólise quando submetidas a $37^{\circ} \mathrm{C}$ e $\mathrm{pH} 7,5$.

No estudo de Padrilha; Augusto-Ruiz (2007), o extrato enzimático da lipase 
comercial pancreática porcina foi utilizado para promover a hidrólise de óleo de pescado a $38^{\circ} \mathrm{C}$ e $\mathrm{pH} 8$, em reator. Os autores obtiveram o resultado de produção de $453 \mathrm{mg} / \mathrm{mL}$ de ácidosgraxos livres.

Lipases de $B$. bassiana e $F$. oxysporum imobilizadas em Octyl foram utilizadas para a hidrólise dos óleos de buriti e açaí. A imobilização neste suporte proporcionou hiperativação enzimática e aumento da estabilidade em diferentes fatores físico-químicos. A hidrólise utilizando o óleo de açaí como substrato demonstrou eficiência na produção de ômegas 6 e 9. Neste mesmo estudo, foi observada a redução de $50 \%$ na formação de produto de hidrólise em 24 horas de reação. O possível motivo para que haja esta queda de formação de produto em 24 horas de reação, deve-se a perda da estabilidade da enzima, uma vez que é utilizada agitação mecânica durante a reação. A agitação pode auxiliar na perda da ligação da enzima ao suporte, levando a diminuição da sua estabilidade e consequentemente perda da eficiência da reação de hidrólise (PÉREZ; ROCHA et al., 2018). 
V - CONCLUSÕES 
Neste trabalho identificou-se o fungo termófilo $S$. thermophilum como um bom produtor de lipase. As condições de cultura foram padronizadas como meio de cultivo SR, suplementado com $1 \%$ de óleo de buriti, incubação por 72 horas, $120 \mathrm{rpm}$ a $40{ }^{\circ} \mathrm{C}$. A imobilização da lipase produzida no suporte de interação iônica Duolite demonstrouse muito eficiente, com índice de retenção de $98,73 \%$ e alta estabilidade, principalmente a temperatura de $50^{\circ} \mathrm{C}, \mathrm{pH} 6$ e 7 e nos solventes ciclohexano, metanol, etanol e acetona, tornando-se uma técnica vantajosa frente ao uso da enzima livre. O derivado de Duolite apresentou excelente atividade de transesterificação $(10,5 \mathrm{U} / \mathrm{g})$ a $50^{\circ} \mathrm{C}$, proporcionando uma taxa de produção de ésteres etílicos de 53,78\%, a partir do óleo de girassol, com $74 \%$ de rendimento e capacidade de reutilização e armazenamento por 3 semanas. Em adição, o biodiesel produzido por este derivado possuiu propriedades que se adequam aos padrões físico-químicos estipulados por normas internacionais que determinam a qualidade do biodiesel.

O fungo mesófilo $A$. phoenicis também se mostrou um excelente produtor de lipases. As condições de cultura foram padronizadas como meio de cultivo SR, suplementado com $1 \%$ de óleo de girassol, incubação por 72 horas, $120 \mathrm{rpm}$ a $30{ }^{\circ} \mathrm{C}$. A imobilização da lipase no suporte hidrofóbico Octyl-sepharose demonstrou-se eficiente, com índice de retenção de $98,83 \%$ e estabilidade em uma faixa ampla de temperatura e pH. Além disso, a imobilização nesse suporte hiperativou a enzima em $20 \%$, possivelmente por estabilizar a conformação aberta da tampa que recobre o sítio catalítico da enzima, deixando o sítio ativo exposto. Essa técnica de imobilização mostrou-se vantajosa frente ao uso da enzima livre. A reação de hidrólise utilizado o derivado de Octyl resultou em valores satisfatórios de ácidos graxos livres. Os melhores resultados foram obtidos usando os óleos de buriti $(3,4 \mathrm{mg} / \mathrm{mL})$, açaí $(3,06 \mathrm{mg} / \mathrm{mL})$ e ojon $(2,278$ $\mathrm{mg} / \mathrm{mL})$.

Portanto, os objetivos propostos para esse trabalho foram alcançados com sucesso, proporcionando novas ideias para futuros estudos que possam abranger a utilização dos biocatalisadores produzidos em diferentes áreas industriais. 
VI - REFERÊNCIAS

BIBLIOGRÁFICAS 
ACIKEL, U.; ERSAN, M.; ACIKE, Y.S. The effects of the composition of growth medium and fermentation conditions on the production of lipase by Rhizopus delemar. Turk. J. Biol, 35, 35-44. 2011.

AGGELIS, G., MAMALAKIS, G., KOMAITIS, M. - Fatty acid specificity (typospecificity) of some microbial lipases. Riv. Ital. Sostanze Grasse, Milano, v. 72, n. 5, p. 211-213, 1995.

AGGER, T.; PETERSEN, J.B.; O’CONNOR, S.M.; MURPHY, R.L.; KELLY, Y.M.; NIELSEN, J. Physiological characterization of recombinant Aspergillus nidulans strain with different A genotypes expressing A. oryzae $\alpha$-amylase. J. Biotechnol., v. 92, p. 279-285, 2002.

AKBARI, N.; DANESHJOO, S.; AKBARI, J.; KHAJEH, K. Isolation, characterization, and catalytic properties of a novel lipase which is activates in ionic liquids and organic solvents. Appl. Biochem. Biotechnol., 165, 785-794. 2011.

AL-ZUHAIR, S.; DOWAIDAR, A.; KAMAL, H. Dynamic modeling of biodiesel production from simulated waste cooking oil using immobilized lipase. Biochem. Eng. J., 44, pp. 256-262. 2009.

AMAZON FOREST TRADING. Amazonas: Manaus, Brasil. 2018. http://amazonforestrading.com.br/.

AMAZON OIL®. AmazonOil Preservando o Futuro. Pará: Levilândia Ananindeua, 2015. https://www.amazonoil.com.br/.

ANDRADE, J. C. Determinações Iodométricas. Chemkeys. Campinas, p. 1-6. fev. 2001.

ANSCHAU, A.; CARUSO, C.S.; KUHN, R.C.; FRANCO, T.T. Validation of the sulfophospho-vanillin (SPV) method for the determination of lipid content in oleaginous microorganisms. Braz. J. Chem. Eng., [s.1.], v. 34, n. 1, p.19-27, jan. 2017.

ANP. AGÊNCIA NACIONAL DE PETRÓLEO, GÁS NATURAL E BIOCOMBUSTÍVEIS. Biodiesel. 2016. Disponível em: <http://www.anp.gov.br> ANP. AGÊNCIA NACIONAL DE PETRÓLEO, GÁS NATURAL E BIOCOMBUSTÍVEIS. Anuário Estatístico Brasileiro do Petróleo, Gás Natural e Biocombustíveis. 2016. Disponível em: <http://www.anp.gov.br $>$

ARAUJO, R. M. Regulação do Biodiesel - Especificação e Controle de Qualidade: 
Superintendência de Qualidade de Produtos. Rio de Janeiro: ANP. 41 p. 2005.

ARICETTI, J. Métodos titulométricos alternativos para a avaliação da qualidade do biodiesel. 2010. 149 f. Dissertação (Mestrado), Instituto de Química Universidade Estadual de Campinas, Campinas, 2010.

AUED-PIMENTEL, S. Ácidos graxos trans em óleos vegetais refinados poli-insaturados comercializados no estado de São Paulo, Brasil. Ciênc. Tecnol. Aliment., Campinas, v. 29, n. 3, p. 646-651. 2009.

BASHA, N.; REKHA, R.; KOMALA, M.; RUBY, S. Production of Extracellular Antileukemic Enzyme L-asparaginase from Marine Actinomycetes by Solid state and Submerged Fermentation: Purification and Characterization. Trop. J. Pharm. Res., 8(4). 2009.

BÉLAFI-BAKÓ, K., KOVÁCS, F., GUBICZA, L., \& HANCSÓK, J. Enzymatic biodiesel production from sunflower oil by Candida antarctica lipase in a solventfree system. Biocat. Biotrans., 20(6), 437-439. 2002.

BELTRÃO, N.E.M; OLIVEIRA, M.I.P. Oleaginosas e seus óleos: Vantagens e Desvantagens para Produção de Biodiesel. EMBRAPA algodão. Campina Grande, PB. 2008.

BÍBLIA, A. T. Provérbios. In Bíblia Sagrada Online. Português. Versão NVI. São Paulo 7Graus Ltda., 2019. Disponível em: < https://www.bibliaon.com/>

BIODIESELBR. Biodiesel no Mundo. 2014. Disponível em: < https://www.biodieselbr.com/biodiesel/mundo/biodiesel-no-mundo>.

BORDINHÃO, C.; AYUB, M. A. Z. Estudo das Condições de Transesterificação Enzimática do Óleo de Soja. In: XXVI Salão de iniciação científica da UFRGS, Porto Alegre. Porto Alegre: Universidade Federal do Rio Grande do Sul. p. 1. 2014.

BORNSCHEUER, U.T. Microbial carboxyl esterase: classification, properties and application in biocatalysis. FEMS Microbiol. Rev., 26, 73-81. 2002.

BRADY, L.; BRZOZOWSKI, A. M.; DEREWENDA, Z.D.; DODSON, E.; DODSON, G.; TOLlEY, S.; TURKENBURG, J.P.; CHRISTIANSEN, L.; HUGEJENSES, B.; NORSKOV, L.; THIM, L.; MENGE, U. A serine protease triad forms the catalytic center of a triacylglycerol lipase. Nature, 343, 767-770. 1990. 
BRADY, D.; JORDAAN, J. Advances in enzyme immobilization. Biotechnol. Lett., 31, 1639-1650. 2009.

CARDENAS, F.; ALVAREZ, E.; CASTRO-ALVAREZ, M.M.; SANCHEZMONTERO, J.M.; VALMASEDA, M.; ELSON, S.W.; SINISTERRA, J.V. Screening and catalytic activity in organic synthesis of novel fungal and yeast lipases. J. Mol. Catalysis B-Enzymatic, 14, 111-123. 2001.

CESAD PORTAL. Determinação de cloro ativo em água sanitária e determinação iodométrica de ácido ascórbico - Aula 15. 2019. Universidade do Sergipe. Disponível em: $<$ http://www.cesadufs.com.br/>

CHAPLIN, M.; BUCKE, C. Enzyme technology. In: CHAPLIN, M.; BUCKE, C. Enzyme technology. Cambridge University Press, 1990.

COLIN, V.L.; BAIGORI, M.D.; PERA, L.M. Effect of environmental conditions on extracellular lipases production and fungal morphology from Aspergillus niger MYA 135. J. Basic Microbiol., v. 50, p. 52-58, 2010.

CUNHA, A.G.; FERNANDEZ-LORENTE, G.; GUTARRA, M.L.E.; BEVILAQUA, J.V.; ALMEIDA, R.V.; PAIVA, L.M.C; FERNANDEZ-LAFUENTE, R.; GUISA, J.M.; FREIRE, D.M.G. Separation and immobilization of lipase from Penicillium simplicissimum by selective adsorption on hydrophobic supports. App. Biochem. Biotechnol., 156, 563-575. 2009.

DAS, A.; BHATTACHARYA, S.; SHIVAKUMAR, S.; SHAKYA, S.; SOGANE, S.S. Coconut oil induced production of a surfactant-compatible lipase from Aspergillus tamarii under submerged fermentation. J. Basic Microbiol, [s.1.], v. 57, n. 2, p.114120, 6 out. 2016 .

DATTA, S.; CHRISTENA, L. R.; RAJARAM, Y. R. S., Enzyme immobilization: an overview on techniques and support materials. 3 Biotechnol., Vol. 3, p. 1-9. 2013.

DU, W; XU, Y.Y; ZENG, J; LIU, D.H. Novozymes 435-catalyzed transesterification of crude soya bean oils for biodiesel production in a solvent-free medium. Appl. Biochem, 40: 187-90. 2004.

DYEBERG, J.; BANG, H. O.; STOFFERSEN, E; MONCADA, S.; VANE, J. R.; LANCET. Eicosapentanoic acid and prevention of thrombosis and atherosclerosis. 
Lancet 2, 117. 1978.

FABER K. Biotransformation in organic chemistry. A textbook. $5^{\mathrm{a}}$ edição. New York: Springer, p. 454, 2004.

FACCHINI, F. D. A. Estudos bioquímicos e moleculares de lipase de Fusarium verticillioides e aplicações biotecnológicas. $214 \mathrm{f}$. Tese (Doutorado) - Curso de Doutorado em Ciências, Universidade de São Paulo, Ribeirão Preto, 2014.

FACCHINI, F. D. A.; VICI, A.C.; PEREIRA, M.G.- Lipases: Imperative Fatdegrading Enzymes. In: Fungal Enzymes, Ed. POLIZELI, M.L.T.M. e RAI, M., CRC Press, 2013.

FACCHINI, F. D. A; VICI, A.C; PEREIRA, M.G; OLIVEIRA, M.F; BATISTA, A.C.F; VIEIRA, A.T; SILVA, T.A; JORGE, J.A., POLIZELI, M.L.T.M. A useful methodology to select lipase-catalyzed transesterification aiming biodiesel application. Revi. Bras. Engenh. Biossis., [s.1.], v. 10, n. 1, p.01-13, 21 mar. 2016. Universidade Estadual Paulista - Campus de Tupã. 2016.

FACIOLI, N.L; GONCALVES, L. A.G. Modificação por via enzimática da composição triglicerídeas do óleo de pequi (Caryocar brasiliense Camb). 1998. Quím. Nova, São Paulo, v.21, n.1, p. 1619. 1998.

FERNANDEZ-LORENTE， G.; CABRERA， Z.; GODOY， C.; FERNANDEZLAFUENTE, R.; PALOMO, J. M.; GUISAN, J. M. Interfacially activated lipases against hydrophobic supports: effect of the support nature on the biocatalytic properties. Process Biochem., v. 43, n. 10, p. 1061-1067. 2008.

FERNANDEZ-LORENTE，G.; FILICE，M.; LOPEZ-VELA，D.; PIZARRO，C.; WILSON, L.; BETANCOR, L.; AVILA, Y.; GUISAN, J. M. Cross-linking of lipases adsorbed on hydrophobic supports: highly selective hydrolysis of fish oil catalyzed by RML. J. Am. Oil Chem. Soc., v. 88, n. 6, p. 801-807. 2011.

FICKERS, P.; NICAUD, J.M.; GAILLARDIN, C.; DESTAIN, J.; THONART, P. Carbon and nitrogen sources modulate lipase production in the yeast Yarrowia lipolytic. J. App. Microbiol., v. 96, p. 742-749, 2004.

FU, X., ZHU, X., GAO, K., DUANT, J. Oil and fat hydrolysis with lipase from Aspergillus sp.- J. Am. Oil Chem. Soc., Champaign, v. 72, n. 5, p. 527-530, 1995. 
GAMBA, M. Produção de biodiesel através de catálise enzimática em líquido iônico. 2009. 135f. Universidade Federal do Rio Grande do Sul, Instituto de Química, Programa de pós-graduação em química, 2009.

GARCIA, R. C.; MARTIM, E. Determinação de parâmetros de qualidade para ésteres etílicos através de análises elementares. In: $8^{\circ}$ CONGRESSO BRASILEIRO DE PESQUISA E DESENVOLVIMENTO EM PETRÓLEO E GÁS, 8., 2015, Curitiba. Anais. Curitiba: Associação Brasileira de P\&d em Petróleo e Gás - Abpg, p. 1 - 8. 2015.

GERPEN, J.V. Biodiesel processing and production. Fuel Process Technol.; 86:1097107. 2005.

GHALY, A.E.; DAVE, D.; BROOKS, M.S.; BUDGE, S. Production of biodiesel by enzymatic transesterification: review. Am. J. Biochem. Biotechnol. 6(2), 54-76. 2010 .

GUPTA, R.; GUPTA, N.; RATHI, P. Bacterial lipases: an overview of production, purification and biochemical properties. Appl. Microbiol. Biotechnol., v. 64, p. 763-781. 2004.

GUPTA, R.; RAHTI, P.; GUPTA, N.; BRADOO, S. Lipase assays for conventional and molecular screening: an overview. Biotechnol. Appl. Biochem., v. 37, p. 63-71. 2003.

HASAN, F.; SHAH, A.A; HAMEED, A. Industrial applications of microbial lipases. Enzyme Microbiol. Technol., v. 39, n. 2, p. 235-25. 2006.

HASAN, F.; SHAH, A. A.; HAMEED, A. Methods for detection and characterization of lipases: A comprehensive review. Biotechnol. Adv, v. 27, n. 6, p. 782-798. 2009.

HIOL, A.; JONZO, M.D.; RUGANI, N.; DRUET, D.; SARDA, L.; COMEAU, L.C Purification and characterization of an extracellular lipase from a thermophilic Rhizopus oryzae strain isolated from palm fruit. Enzyme Microbiol. Technol., v. 26, p. 421-430, 2000.

JAENICKE, R. Protein stability and molecular adaptation to extreme conditions. Eur. J. Biochem., v. 202, p. 715-728, 1991.

KHANNA, P.; SUNDARI, S.S; KUMAR, N.J. Production, isolation and partial 
purification of xylanase from Aspergillus sp. World J. Microbiol. Biotechnol., v.11, p 242- 243, 1995.

KHOR, H. T., TAN, N. H., CHUA, C. L.- Lipase-catalyzed hydrolysis of palm oil. J. Am. Oil Chem. Soc., Champaign, v. 63, n. 4, p. 538-540, 1986.

KIRAN, G. S., SHANMUGHAPRIYA, S., JAYALAKSHMI, J., SELVIN, J., GANDHIMATHI, R., SIVARAMAKRISHNAN, S., NATARAJASEENIVASAN, K. Optimization of extracellular psychrophilic alkaline lipase produced by marine Pseudomonas sp. (MSI057). Bioprocess Biosyst. Eng., 31(5), 483-492. 2008.

KO, W.; WANG, I.T.; ANN, P.J. A simple method for detection of lipolytic microorganisms in soils. Soil Biol. Biochem., 37, 597-599. 2005.

KOURMENTZA, C.; ECONOMOU, C. N.; TSAFRAKIDOU, P.; KORNAROS, M. Spent coffee grounds make much more than waste: Exploring recent advances and future exploitation strategies for the valorization of an emerging food waste stream. J. Clean Prod., Vol. 172, p. 980 - 992, 2018.

KREMER, T.O. Resinas de Troca Iônicas. São Paulo: Kurita do Brasil, 2007. Apostila. LARSSON, S.C.; KUMLIN, M.; INGLEMAN-SUNDBERG, M.; WOLK, A. Dietary long-chain n-3 fatty acids for the prevention of cancer: a review of potential mechanisms. Am. J. Clin. Nutr. 79:935-945. 2004.

LAKSHMI, B. S.; KANGUEANE, P.; ABRAHAM, B.; \& PENNATHUR, G. Effect of vegetable oils in the secretion of lipase from Candida rugosa (DSM 2031). Lett. App. Microbio., 29(1), 66-70. 1999.

LIMA, V.M.G.; KRIEGER, N.; SARQUIS, M.I.M.; MITCHELL, D.A.; RAMOS, L.P.; FONTANA, J.D. Effect of nitrogen and carbon sources on lipase production by Penicillium aurantiogriseum. Food Technol. Biotechnol., v. 41, n. 2, p. 105-110, 2003.

LINFIELD, W. M.; O'BRIEN, D. J.; SEROTA, S.; BARUSKAS, R. A. Lipid-lipase interactions 1. Fat splitting with lipase from Candida rugosa, J. Am. Oil Chem. Soc., Champaign, v. 61, n. 6, p. 1067-1071, 1984.

LOBO, I. P.; FERREIRA, S. C; CRUZ, R. S. Biodiesel: parâmetros de qualidade e métodos analíticos. Quím. Nova, São Paulo, v. 32, n. 6, p. 1596-1608, 2009. 
LOWRY, O. H.; ROSEBROUGH, N. J.; FARR, A. L; RANDALL, R. J. Protein measurement with the Folin-Phenol reagent. J. B. C.., v. 193, p; 265-276, 1951.

MACEDO, G. A.; MACEDO, J. A. Produção de biodiesel por transesterificação de óleos vegetais. Biotech. Ciênc. Desenvolv., v.32, p.38-46. 2004.

MACHADO, S. A. Estudo da produção de biodiesel a partir do óleo de Macaúba (Acrocomia aculeata) pela rota etílica. Dissertação (Mestrado em Ciências) Escola de Engenharia de Lorena, Universidade de São Paulo, Lorena, 2013.

MAGALHÃES, P. S. Estudo da reação de transesterificação enzimática do óleo de palma e do comportamento das fases envolvidas. Dissertação (Doutorado em Ciências) - Engenharia Química, COPPE, Universidade Federal do Rio de Janeiro, Rio de Janeiro, 2014.

MANOEL, E. A.; SANTOS, J. C. S.; FREIRE, D. M. G.; RUEDA, N.; FERNANDEZLAFUENTE, R. Immobilization of lipases on hydrophobic supports involves the open formof the enzyme. Enzyme Microbiol. Technol. 2015.

MATEO, C.; ABIAN, O.; FERNANDEZ-LORENTE, G.; PEDROCHE, J.; FERNANDEZ-LAFUENTE, R.; GUISAN, J. M.; TAM, A.; DAMINATI, M. Epoxy sepabeads: a novel epoxy support for stabilization of industrial enzymes via very intense multipoint covalent attachment. Biotechnol. Prog., Vol. 18, p. 629634. 2002.

MATEO, C.; PALOMO, J.M; FERNANDEZ-LORENTE,G.; GUISAN,J.M.; FERNANDEZ-LAFUENTE, R. Improvement of enzyme activity, stability and selectivity via immobilization techniques. Enzyme Microbiol. Technol., Vol. 40, p. 1451-1463. 2007.

McILVAINE, T.C. A buffer solution for colorimetric comparisons. J. Biol. Chem., v.49, p.185-186, 1921.

MENDES, A. A.; DE CASTRO, H. F.; ANDRADE, G. S. S.; TARDIOLI, P. W.; GIORDANO, R. L. C. Preparation and application of epoxy-chitosan/alginate support in the immobilization of microbial lipase by covalent attachment. React. Funct. Polym., v. 73, p. 160-167. 2013.

MENDES, A.A.; CASTRO, H. F.; RODRIGUES, D.S.; ADRIANO, W.S.; TARDIOLI, 
P.W.; MAMMARELLA, E.; GIORDANO, R.C.; GIORDANO, R.L.C. Multipoint covalent immobilization of lipase on chitosan hybrid hydrogels: influence of the polyelectrolyte complex type and chemical modification on the catalytic properties of the biocatalysts. J. Ind. Microbiol. Biotechnol., v. 38, p.1055-1066, 2010.

MELO, P. G. Produção e caracterização de biodiesel obtidos a partir da oleaginosa Macaúba (Acrocomia aculeata). 93 f. Dissertação (Mestrado em Ciências Exatas e da Terra) - Universidade Federal de Uberlândia, Uberlândia, 2012.

MENEGHETTI, S.M.P.; MENEGHETTI, M.R.; BRITO, Y.C. A reação de transesterificação, algumas aplicações e obtenção de biodiesel. Rev. Virt. Quím. 5(1), 63-73. 2013.

MICHELIN, M. Potencial dos fungos Aspergillus terricola e Aspergillus ochraceus no desenvolvimento de bioprocessos e propriedades das enzimas xilanolíticas. Ribeirão Preto, Tese (Doutorado em Ciências, Área: Biologia Comparada) Faculdade de Filosofia, Ciências e Letras de Ribeirão Preto - USP. 2009.

MITCHELL, D. A.; KRIEGER, N.; STUART, D. M.; PANDEY, A. New developments in solid state fermentation. II. Rational approaches to the design, operation and scale-up of bioreactors. Process Biochem., v. 35, p. 1211-1225. 2000.

MORENO-PEREZ, S.; GUISAN, J. M.; FERNANDEZ-LORENTE, G. Selective ethanolysis of fish oil catalyzed by immobilized lipases. J. Am. Oil Chem. Soc., v. 91, n. 1, p. 63-69, 2014.

MORONI, L.; GELLINI, C.; SALVI, P. R. Thermal denaturation of protein and chemical equilibrium. World J. Chem. Edu., Vol. 3, p. 59-63, 2015.

NARWAL, S.K.; GUPTA, R. Biodiesel production by transesterification using immobilized lipase. Biotechnol. Lett. 35: 479. 2013.

NASCIMENTO, R.J.S. Composição em ácidos graxos do óleo da polpa de açaí extraído com enzimas e com hexano. Rev. Bras. Frutic., Jaboticabal, v. 30, n. 2, p. 498502. 2008.

NELSON, D. L.; COX, M. M. Princípios de Bioquímica de Lehninger. $6^{\text {a }}$ edição. Porto Alegre: Artmed, 2014.

NELSON, L. A.; FOGLIA, T. A.; MARMER, W. N. Lipase-catalyzed production of 
biodiesel. J. Am. Oil Chem. Soc., 73(9). 1996.

NETO, P. R. C.; ROSSI, L. F.; ZAGONEL, G. F.; RAMOS, L. P. Produção de biocombustível alternativo ao óleo diesel através da transesterificação de óleo de soja usado em frituras. Química Nova, 23(4), 531-537. 2000.

NOUREDDINI, H; GAO, X; PHILKANA, R.S. Immobilized Pseudomonas cepacia lipase for biodiesel production from soybean oil. Bioresour. Technol., 96: 769-77. 2005.

OLIVEIRA, D; DI LUCCIO, M'FACCIO, C; ROSA, C.D; BENDER, J.P; LIPKE, N. Optimization of enzymatic production of biodiesel from castor oil in organic solvent medium. Appl. Biochem. Biotechnol., 113(116): 771-80. 2004.

OLIVEIRA, D. S.; FONSECA, X. D. S.; FARIAS, P. N.; BEZERRA, V. S.; PINTO, C. H. C.; SOUZA, L. D.; SANTOS, A. G. D.; MATIAS, L. G. O. Obtenção do biodiesel através da transesterificação do óleo de Moringa oleífera lam. Ed. Holos, 28(1), 49-61. 2012.

OZNUR, K.; TUTEN, M.; AKSOY, H. A. Enzymatic transesterification for biodiesel production. Bioresour. Technol., 83, 125. 2002.

PADHIAR, I., DAS, A. AND BHATTACHARYA, S. Candida albicans and Aspergillus flavus. Pakistan J. Biol. Sci., v. 14, n. 22, p. 1011-1018, 2011.

PALOMO, J.M.; FERNANDEZ-LORENTE, G.; MATEO, C.; ORTIZ, C.; FERNANDEZ-LAFUENTE, R; GUISAN, J.M. Modulation of the enantioselectivity of lipases via controlled immobilization and medium engineering: hydrolic resolution of mandelic acid esters. Enzyme Microbiol. Technol., 31, 775-783. 2002.

PALOMO, JM.; SEGURA, R.L; FERNANDEZ-LORENTE, G.; PERNAS, M.; RUA, M.L.; GUISAN, J.M; FERNANDEZ-LAFUENTE, R. Purification, immobilization and stabilization of lipase from Bacillus thermocatenulatus by interfacial adsorption on hydrophobic supports. Biotechnol. Progress, 20, 630-635. 2004.

PALOMO, J. M; FERNANDEZ-LORENTE, G; MATEO, C; SEGURA, R. L; ORTIZ, C; FERNANDEZ-LAFUENTE, R; GUISAN, J. M. Purification, immobilization, hyperactivation, and stabilization of lipase by selective adsorption on hydrophobic 
supports. In: GUISAN, J. M. Immobilization of enzymes and cells $2^{\text {nd }}$ ed. Madrid: Humana Press. Cap 13, p.130-143. 2006.

PALOMO, J.M.; MUNOZ, G.; FERNANDEZ-LORENTE, G.; MATEO, C.; FERNANDEZ-LAFUENTE, R; GUISAN, J.M. Interfacial adsorption of lipases on very hydrophobic support (octadecyl-Sepabeads): immobilization, hyperactivation and stabilization of the open form of lipases. J. Mol. Catalysis B-Enzymatic, 19, 279-286. 2002.

PEIXOTO, S.C. Estudos comparativos entre amilases produzidas em cultivo submerso e em substrato sólido pelo fungo termo tolerante Rhizopus microsporus var. rhizopodiformis. Purificação e caracterização enzimática. Ribeirão Preto, Dissertação (Mestrado em Ciências, Área: Biologia Comparada) Faculdade de Filosofia, Ciências e Letras de Ribeirão Preto - USP.2004.

PELCZAR, M.J.; CHAN, E.C.S.; KRIEG, N.R. Microbiol. Conceitos e Apl. São Paulo. Pearson Makron Books. Segunda edição, v. 1, 524 p., 1996.

PENCREAC'H, G.; BARATTI, J.C. Hydrolysis of $p$-nitrophenyl palmitate in n-heptane by Pseudomonas cepacia lipase: a simple test for the determination of lipase activity in organic media. Enzyme Microbiol. Technol., v. 18, p 417-22, 1996.

PEREIRA, M.G; FACCHINI, F.D.A; FILO, L.E.C; POLIZELI, A.M; VICI, A.C; JORGE, J.A; LORENTE, G.F; PESSEL, B.C; GUISAN, J.M; POLIZELI, M.L.T.M. Immobilized lipase from Hypocrea pseudokoningii on hydrophobic and ionic supports: Determination of thermal and organic solvent stabilities for applications in the oleochemical industry. Process. Biochem., London, v. 50, n. 4, p. 561-570. 2015.

PÉREZ, M.M.; GONÇALVES, E.C.S.; SALGADO, J.C.S.; ROCHA, M.S.; ALMEIDA, P.Z.; VICI, A.C.; INFANTE, J.C.; GUISÁN, J.M.; ROCHA-MARTIN, J.; PESSELA, B.C.; POLIZELI, M.L.T.M. Production of omegas-6 and 9 from the hydrolysis of açaí and buriti oils by lipase immobilized on a hydrophobic support. Molecules, 23, 3015. 2018.

PÉREZ, M. M., MARTINS, L. M. S.; DIAS, M. S.; PEREIRA, C. A.; LEITE, J. A.; GONÇALVES, E. C. S.; CARLOS, D. IL-17/IL-17R axis elicits intestinal neutrophil migration, restrains gut dysbiosis and LPS translocation in high-fat diet- 
induced metabolic syndrome model. Immunol., 156(4):339-355, 2018.

PÉREZ, M. M.; SPIROPUlOS, E. C. G.; VICI, A. C.; SALGADO, J. C. S.; POLIZELI. Fungal Lipases - Versatile Tools for White Biotechnology. In: YADAV, A. N.; MISHRA, S.; SINGH, S.; GUPTA, A. Recent Advancement in White Biotechnology Through Fungi. (cap 11). Springer, 2018.

PIGHINELLI, A. L. M. T. Otimização da prensagem de grãos de girassol e sua caracterização. Rev. Bras. Eng. Agríc. Ambient., Campina Grande, v. 13, n. 1, p. 63-67, Feb. 2009.

POTRICH, E., AMARAL, L. S., \& RAVASI, T. C. Periculosidade e riscos dos principais álcoois utilizados na produção de biodiesel. J. Basic App. Pharma. Sci., 39(1). 2018.

RANGANATHAN, S.V; NARASIMHAN, S.L.; MUTHUKUMAR, K. An overview of enzymatic production of biodiesel. Bioresour. Technol.; 99:3975-3981. 2008.

RIZZATTI, A.C.S.; JORGE, J. A.; TERENZI, H.F.; RECHIA, C.G.V.; POLIZELI, M.L.T.M. Purification and properties of a thermostable extracellular-D-xylosidase produced by thermotolerant Aspergillus phoenicis. J. Ind. Microbiol. Biotechnol., v.26, p. 96-100 156-160, 2001.

RODRIGUES, H.S. Obtenção de ésteres etílicos e metílicos, por reações de transesterificação, a partir do óleo da palmeira Latino Americana Macaúba Acrocomia aculeata. 236p. Dissertação (Doutorado em Ciências) - Faculdade de Filosofia, Ciências e Letras de Ribeirão Preto, Universidade de São Paulo, Ribeirão Preto, 2007.

RODRIGUES, R.C.; VOLPATO, G.; WADA, K.; AYUB, M.A.Z. J. Utilization of immobilized lipases as catalysts in the transesterification of non-edible vegetable oils with ethanol. Oil Chem. Soc. 85 (2008) 925-930. 2008.

ROSA, D.R.; DUARTE, I.C.S.; SAAVEDRA, N.K.; VARESCHE, M.B.; ZAIAT, M.; CAMMAROTA, M.C.; FREIRE, D.M.G. Performance and molecular evaluation of an anaerobic system with suspended biomass for treating wastewater with high fat content after enzymatic hydrolysis. Bioresour. Technol., 100, 6170-6176. 2009.

SALDANHA, E. S. P. B., GONZALES, E. Enriquecimento de ácidos graxos na 
alimentação poedeiras. Pesq. Tecnol. São Paulo, p. 1-5. jun. 2012.

SAMAD, M.Y.A.; RAZAK, C.N.A; SALLEH, A.; YUNUS, W.; AMPON, K.; BASRI, M. A plate assay for primary screening of lipase activity. J. Microbiol. Meth., 9, 51-56. 1989.

SANGALETTI, N. Transesterificação química e enzimática de miscela etanólica de óleo de soja. 2012. Tese (Doutorado em Química na Agricultura e no Ambiente) Centro de Energia Nuclear na Agricultura, Universidade de São Paulo, Piracicaba, 2012.

SANTI, G. V. S., ESCORSIM, A. M., DE FREITAS, C. H., CARDOSO, J. L. L., \& DA SILVEIRA, M. L. R. Avaliação da eficiência do etanol e do metanol em processos de esterificação na produção de biodiesel. Anais do EVINCI-UniBrasil, 3(1), 1111. 2018.

SARMAH, N.; REVATHI, D.; SHEELU, G.; RANI, K.Y.; SRIDHAR, S.; MEHTAB, V.; SUMANA, C. Recent advances on sources and industrial applications of lipases. Biotechnol. Prog, Vol 34, p. 5-28. 2018.

SAXENA, R. K.; GHOSH, P. K.; GUPTA, R.; DAVIDSON, W. S.; BRADOO, S.; GULATI, R. Microbial lipases: potential biocatalysts for the future industry. Cur. Sci., Bangalore, v. 77, n. 1, p. 101-115. 1999.

SCHON, A.; CLARKSON, B. R.; JAIME, M.; FREIRE, E. Temperature stability of protein: analysis of irreversible denaturation using isothermal calorimetry. Proteins. 2017.

SECUNDO, F., Conformational changes of enzyme upon immobilization. Chem. Soc. Rev., Vol. 42, p. 6250, 2013.

SHAH, S.; SHARMA, S.; GUPTA, M. N. Biodiesel Preparation by Lipase-Catalyzed Transesterification of Jatropha Oil. Energy \& Fuels, 18(1), 154-159. 2004.

SHIMADA, Y.; WATANABE, Y.; SUGIHARA, Y.; TOMINAGA, Y. Review: Enzymatic Alcoholysis For Biodiesel Fuel Production and Application of The Reaction to Oil Processing. J. Molec. Cataly. B: Enzymatic, 17: p. 133-142. 2002.

SHIMADA, Y.; WATANA, Y.; SAMUKAWA, T.; SUGIHARA, A.; NODA, H.; FUKUDA, H; TOMINAGA, Y. Conversion of vegetable oil to biodiesel using 
immobilized Candida antarctica lipase. Oil Chem. Soc. 76. 789-793. 1999.

SHU, Z.Y.; YANG, J.K.; YAN, Y.J. Purification and characterization of a lipase from Aspergillus niger F044. Chin. J. Biotechnol., v. 23, p. 96-100, 2007.

SINGH, A. K.; MUKHOPADHYAY, M. Overview of fungal lipase: a review. Appl. Biochem. Biotechnol., Vol. 166, p. 486-520. 2012.

SOARES, L. R. A. Produção de biodiesel em reator contínuo irradiado com microondas via transesterificação com catalisador homogêneo. Dissertação (Mestrado). Engenharia Química, UFMG, Belo Horizonte. 2015.

SOUZA, L. T. A.; MORENO-PEREZ, S.; LORENTE, G. F.; CIPOLATTI, E. P.; DE OLIVEIRA, D.; RESENDE, R. R.; PESSELA, B. C. Immobilization of Moniliella spathulata R25L270 lipase on ionic, hydrophobic and covalent supports: Functional properties and hydrolysis of sardine oil. Molecules. 2017.

SOUZA, L. T.A; VERÍSSIMO, L.A.A; PESSELA, B.C.; SANTORO, M.M; RESENDE, R. R.; MENDES, A. A. Imobilização enzimática: princípios fundamentais e tipos de suporte. In: Biotec. Apli. Agro\&Indústria - Vol. 4", p. 529 -568. São Paulo: Blucher. ISBN: 9788521211150. 2017.

TELlO, A.; CAO, R.; MARCHANT, M. J.; GOMEZ, H. Conformational changes of enzymes and aptamers immobilized on electrodes. Bioconjugate Chem., Vol. 27, p. 2581-2591, 2016.

TREVISAN, H.C. Lipases. In: Said, S.; Pietro, R.C.L.R. Enzimas como agente Biotecnológico. 1. ed. Ribeirão Preto: Editora Legis Summa, p. 115-135. 2004.

TSUJISAKA, Y.; OKUMURA, S.; IWAI, M. Glyceride synthesis by four kinds of microbial lipase. Biochem. Biophys. Acta, 489 - 415. 1977.

VIEIRA, A.P.A.; SILVA, M.A.P.; LANGONE, M.A.P. Biodiesel production via esterification reactions catalyzed by lipase. Lat. Am. Appl. Res., v.36, p.283-288. 2006.

VICI, A. C. Produção, purificação e imobilização de lipases produzidas por Beauveria brongniartii. 139 f. Dissertação (Mestrado). Bioquímica, FMRP-USP, Ribeirão Preto. 2010.

VICI, A. C. Clonagem, expressão e imobilização de uma lipase de Beauveria bassiana 
com aplicação em biocatálise. 188 f. Tese (Doutorado) - Curso de Doutor em Ciências, Departamento de Bioquímica e Imunologia, Universidade de São Paulo, Ribeirão Preto, 2015.

WANG, D.L.; NAG, A.; LEE, G.C.; SHAW, J.F. Factors affecting the resolution of dlmenthol by immobilized lipase-catalyzed esterification in organic solvent. J. Agric. Food Chem., v. 50, p. 262-265, 2002.

YAN, Y.; LI, X.; WANG, G. Biotechnological preparations of biodiesel and its highvalued derivatives: A review. Appl. Energy.113:1614-31.2013.

ZAMBELli, R. A. Determinação da densidade de óleos.: Processamento de Óleos Vegetais. Fortaleza: Universidade Federal do Ceará - Centro de Ciências Agrárias, 2009.

ZHENG-YU, S.; JIANG-KE, Y.; YUN-JUN, Y. Purification and characterization of lipase from Aspergilus niger F044. Chin. J. Biotechnol., v.23, n .1, p. 96-100, 2007.

ZHANG, Y.; ROCHEFORT, D. Activity, conformation and thermal stability of laccase and glucose oxidase in poly(ethyleneimine) microcapsules for immobilization in paper. Process. Biochem., 46, 993-1000. 2011.

ZHANG, B.; WENG, Y.; XU, H.; MAO, Z. Enzyme immobilization for biodiesel production. App. Microbiol. Biotechnol., v. 93, p. 61-70. 2012. 
ANEXOS 


\section{ANEXO I}

\section{Meios de cultivo}

\section{$\underline{\text { Meio de Cultura de Aveia sólido }}$}

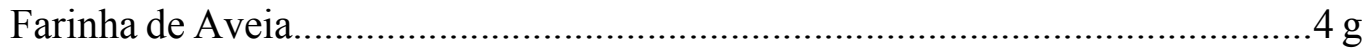

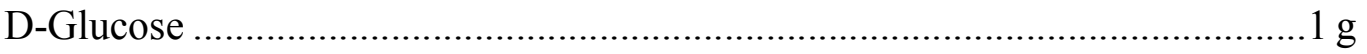

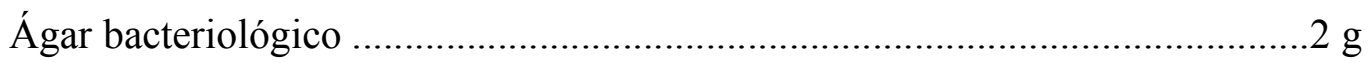

Água destilada q.s.p ................................................................... $100 \mathrm{~mL}$

Meio de Cultura SR (RIZZATTI et al., 2001)

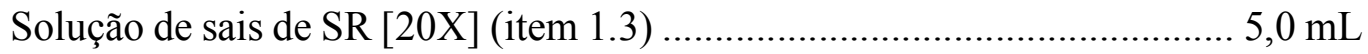

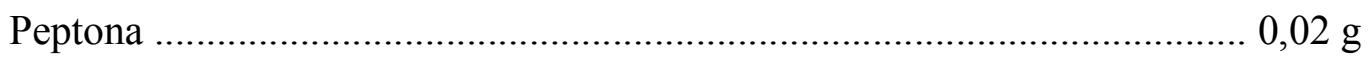

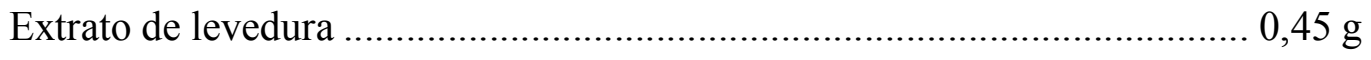

Fonte de Carbono ….................................................................... 1,0 g

Água destilada q.s.p .................................................................... $100 \mathrm{~mL}$

- $\quad$ Solução de sais SR [20X]

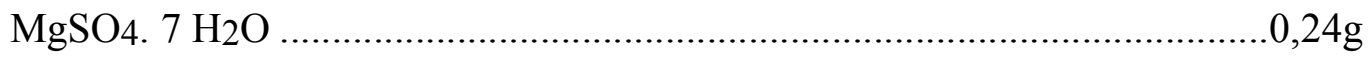

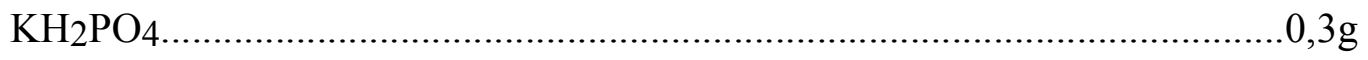

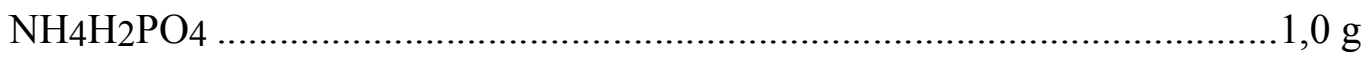

Água destilada q.s.p ..................................................................100 mL 
Meio de cultura Khanna (KHANNA et al., 1995)

Solução de sais de Khanna [20X] $5,0 \mathrm{~mL}$

Extrato de levedura $0,1 \mathrm{~g}$

Fonte de Carbono $1,0 \mathrm{~g}$ Água destilada q.s.p $100 \mathrm{~mL}$

- Solução de sais de Khanna [20X]

$\mathrm{NH}_{4} \mathrm{NO}_{3}$ $2,0 \mathrm{~g}$

$\mathrm{KH}_{2} \mathrm{PO}_{4}$ $1,3 \mathrm{~g}$

$\mathrm{MgSO}_{4} .7 \mathrm{H}_{2} \mathrm{O}$ $.0,362 \mathrm{~g}$

$\mathrm{KCl}$ $0,098 \mathrm{~g}$

$\mathrm{ZnSO}_{4} \cdot \mathrm{H}_{2} \mathrm{O}$ $.0,007 \mathrm{~g}$

$\mathrm{MnSO}_{4} . \mathrm{H}_{2} \mathrm{O}$ $0,0138 \mathrm{~g}$

$\mathrm{FeCl}_{3} .6 \mathrm{H}_{2} \mathrm{O}$ $.0,0066 \mathrm{~g}$ $\mathrm{CuSO}_{4} .5 \mathrm{H} 2 \mathrm{O}$ $0,0062 \mathrm{~g}$ Água destilada q.s.p. $100 \mathrm{~mL}$ 
ANEXO II

Dosagem enzimática

Meio Reacional (PENCREAC'H; BARATTI, 1996)

- Solução I:

Goma arábica $0,05 \mathrm{~g}$

Tampão citrato-fosfato (100 mM, pH 5,4) (McIlvaine, 1921) $90 \mathrm{~mL}$

Triton X-100 $250 \mu \mathrm{L}$

- Solução II:

p-nitrofenilpalmitato $.0,030 \mathrm{~g}$ Isopropanol $10 \mathrm{~mL}$

A solução I foi homogeneizada por 25 minutos e estocada a $4{ }^{\circ} \mathrm{C}$. A solução II foi homogeneizada por 5 minutos e estocada a $-20^{\circ} \mathrm{C}$. As duas soluções foram misturadas minutos antes de sua utilização e homogeneizadas por 10 minutos. A solução resultante não pode ser estocada. 


\section{ANEXO III}

\section{Dosagem de proteínas}

Solução de Lowry (LOWRY, 1951)

Solução A) $\mathrm{Na}_{2} \mathrm{CO}_{3} 2 \%$ em NaOH $0,1 \mathrm{M}$

Solução B) $\mathrm{CuSO}_{4} 1 \%$ em $\mathrm{H}_{2} \mathrm{O}$

Solução C) Tartarato de $\mathrm{Na}$ e $\mathrm{K} 1 \%$ em $\mathrm{H}_{2} \mathrm{O}$

A solução de Lowry foi preparada pela mistura das soluções A, B e C, na proporção 100:1:1. 
ANEXO IV

Soluções para titulação de biodiesel

Solução de tiossulfato de sódio $0,1 \mathrm{~mol} \mathrm{~L}^{-}$(ANDRADE, 2001)

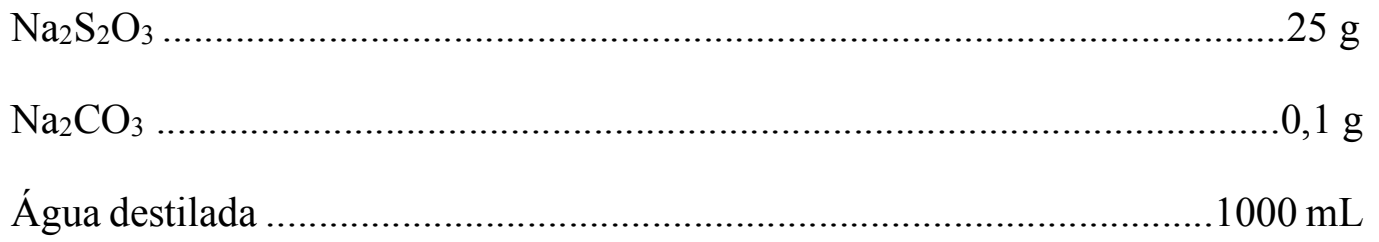

Foram dissolvidos $25 \mathrm{~g}$ de $\mathrm{Na}_{2} \mathrm{~S}_{2} \mathrm{O}_{3}$ em um litro de água destilada recentemente fervida e resfriada, em seguida adicionou-se $0,1 \mathrm{~g}$ de carbonato de sódio e 3 gotas de clorofórmio.

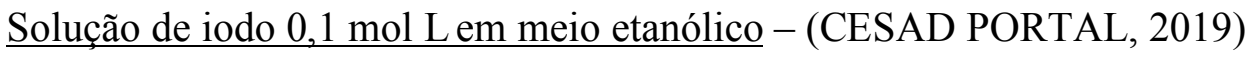

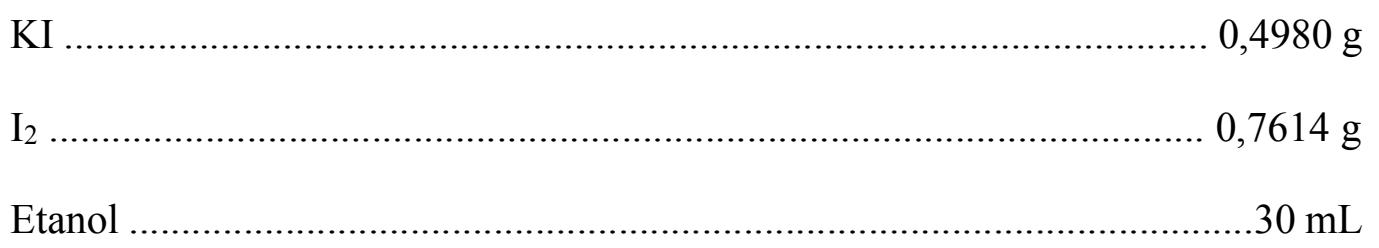

O iodeto de potássio foi dissolvido em $30 \mathrm{~mL}$ de etanol. Em seguida, o iodo puro foi pesado e transferido para a solução contendo KI. A solução foi homogeneizada e armazenada.

Solução de amido 1\% m/v (ANDRADE, 2001)

Amido solúvel $0,5 \mathrm{~g}$

Água destilada $50 \mathrm{~mL}$

O amido solúvel foi adicionado a $3 \mathrm{~mL}$ de água destilada, posteriormente $50 \mathrm{~mL}$ de água destilada quente foi adicionado, sob agitação. Prosseguiu-se a agitação até obtenção de uma solução clara. Por fim, a solução foi filtrada e armazenada. 